\title{
HYDROLOGY OF AREA 3, EASTERN COAL PROVINCE, PENNSYLVANIA
}

- LOWER ALLEGHENY RIVER

- KISKIMINETAS FRIVER

- MAHONING CREEK

- REDBANK CREEK

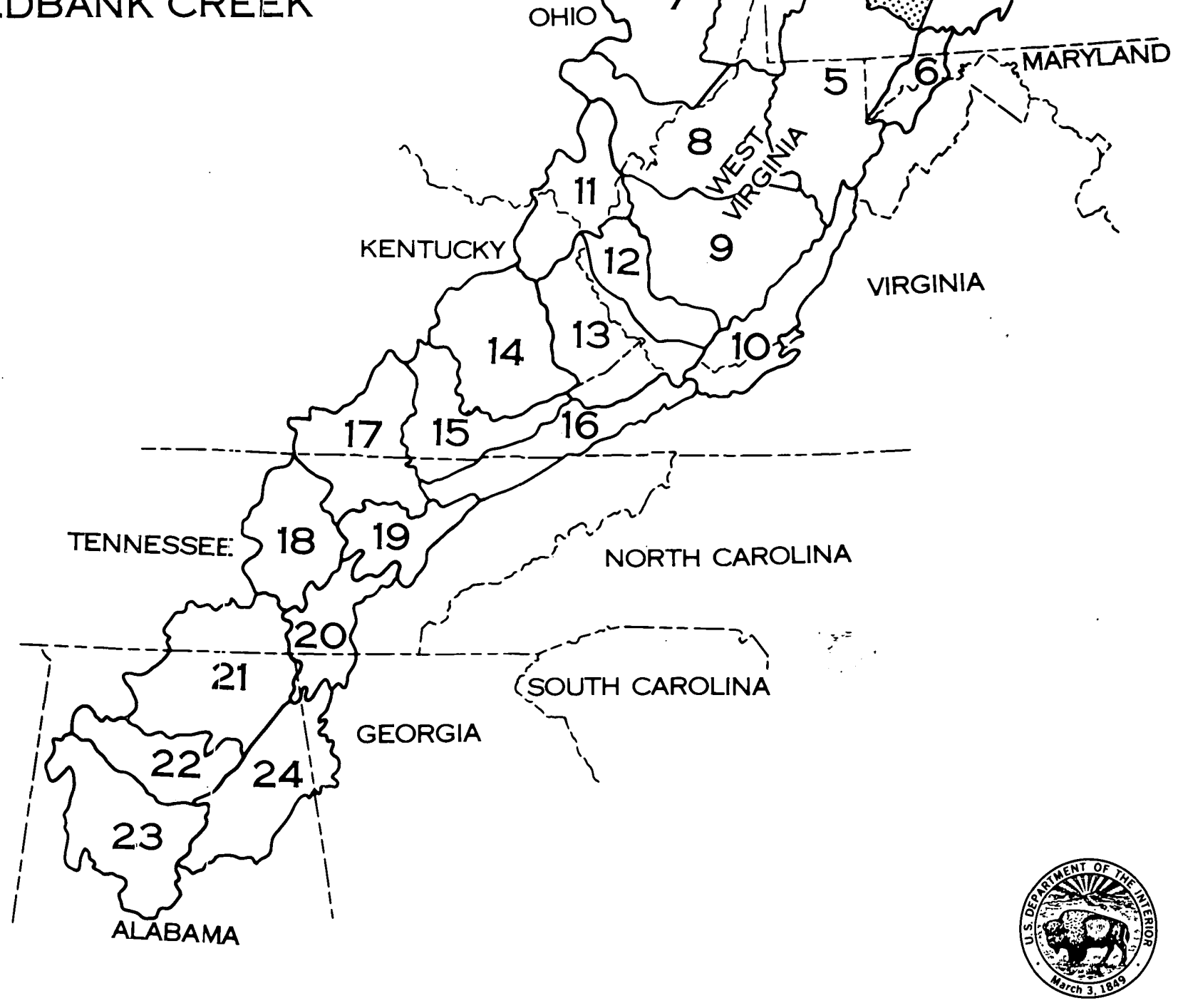

UNITED STATES DEPARTMENT OF THE INTERIOR GEOLOGICAL SURVEY 
.

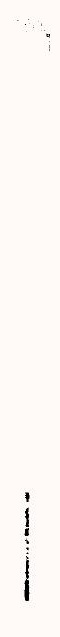
. 


\section{HYDROLOGY OF AREA 3, EASTERN COAL PROVINCE, PENNSYLVANIA}

BY

WILLIAM J. HERB, LEWIS C. SHAW, AND DEBORAH E. BROWN

U.S. GEOLOGICAL SURVEY

WATER-RESOURCES INVESTIGATIONS 81-537

1. 


\title{
UNITED STATES DEPARTMENT OF THE INTERIOR
}

JAMES G. WATT, SECRETARY

\section{GEOLOGICAL SURVEY}

\author{
Doyle G. Frederick, Acting Director
}

For additional information write to:

U.S. Geological Survey

Federal Building

P.O. Box 1107

Harrisburg, Pennsylvania 17108 


\section{CONTENTS}

Page

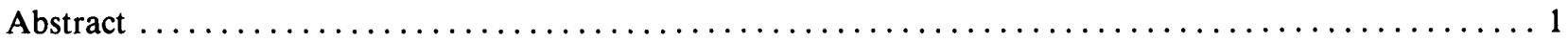

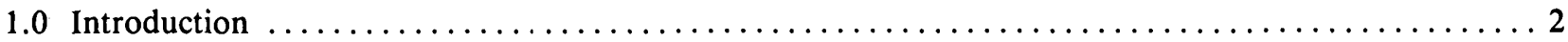

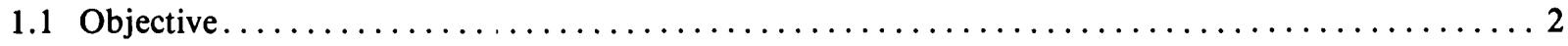

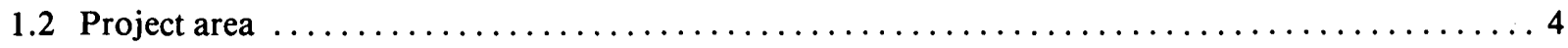

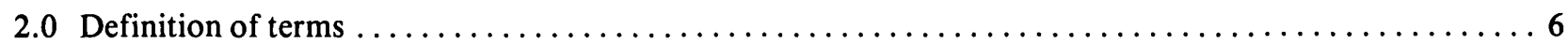

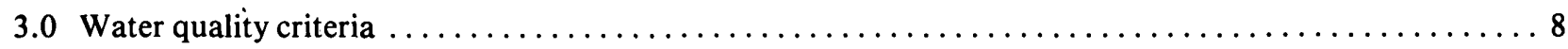

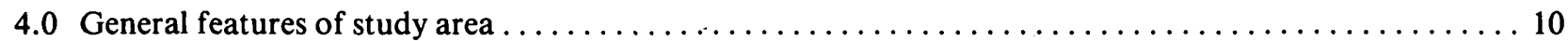

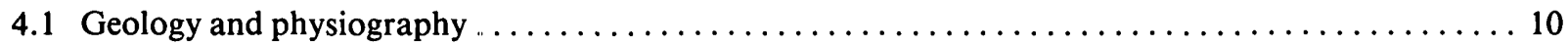

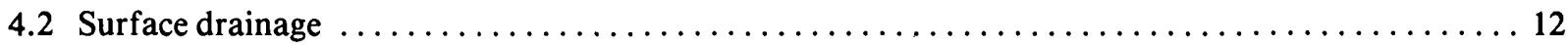

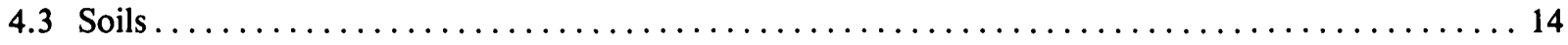

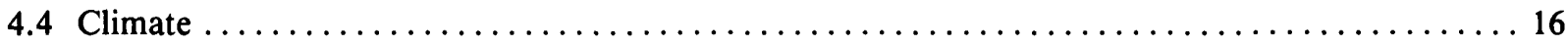

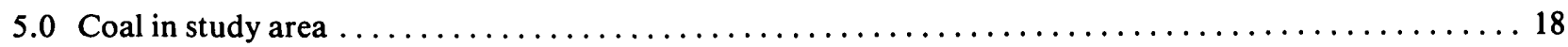

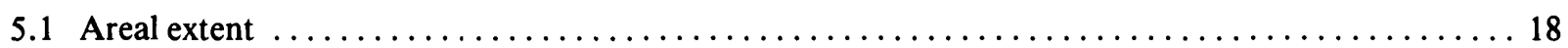

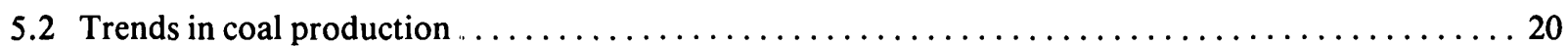

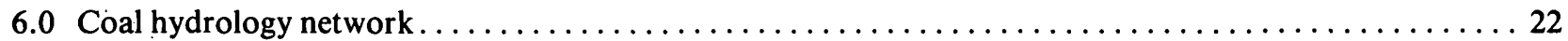

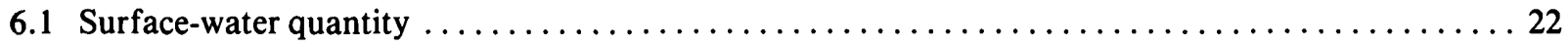

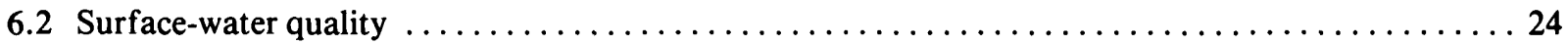

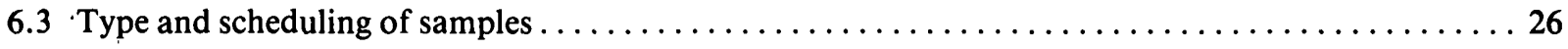

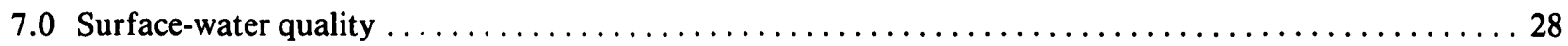

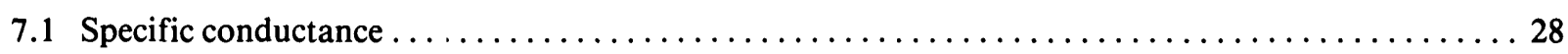

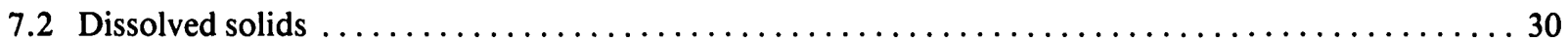

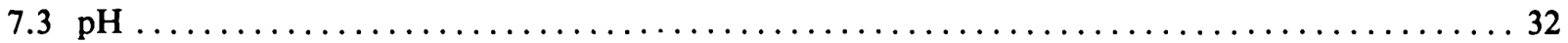

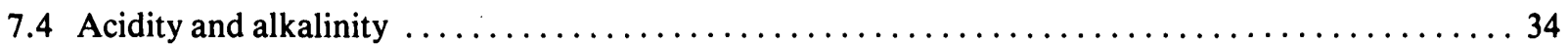

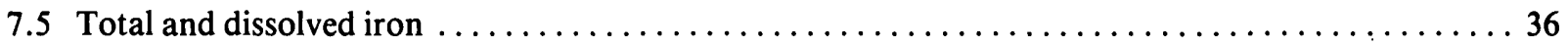

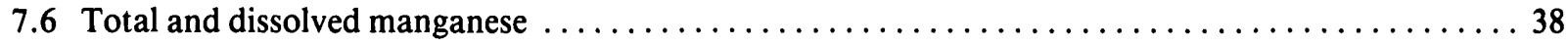

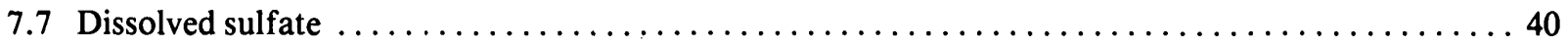

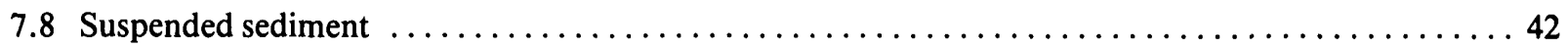

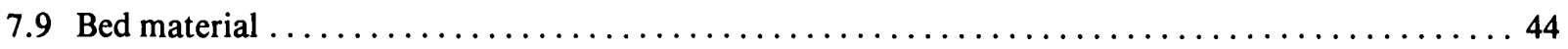

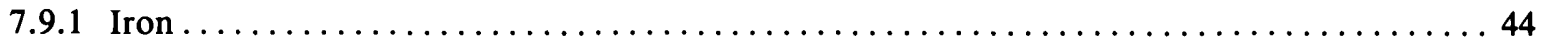

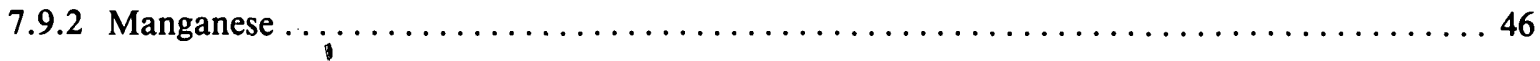




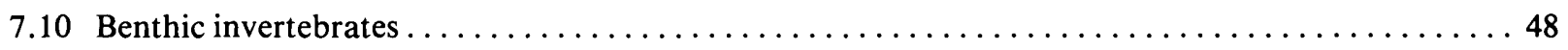

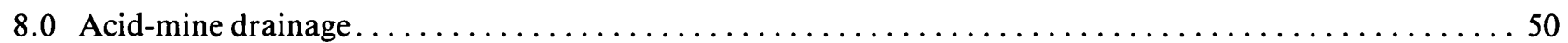

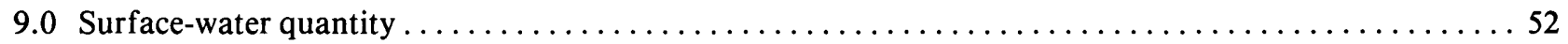

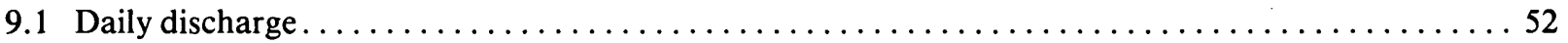

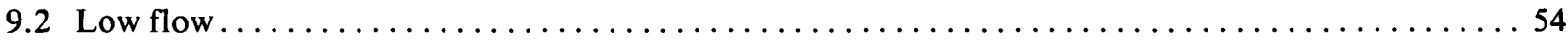

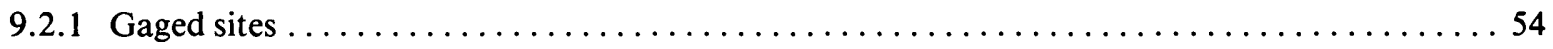

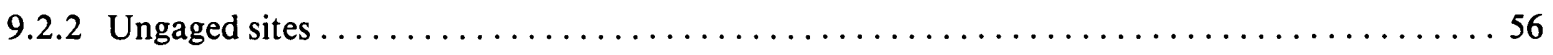

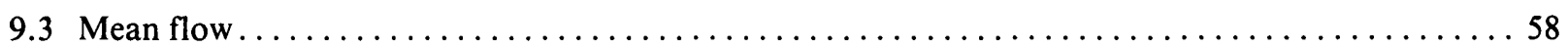

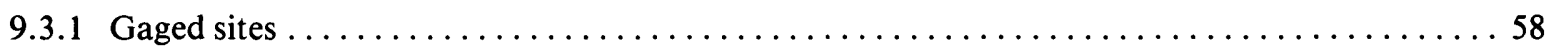

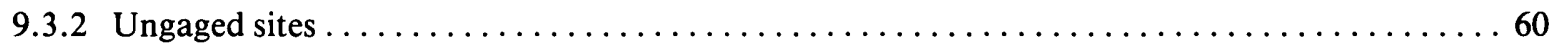

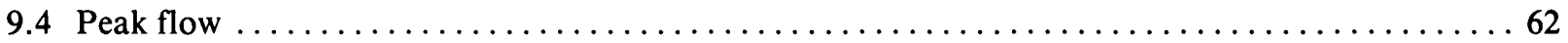

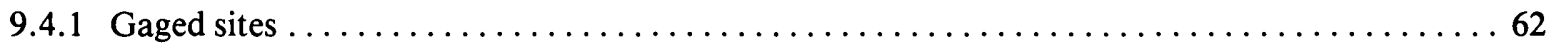

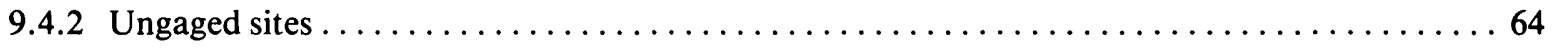

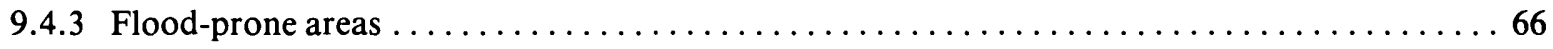

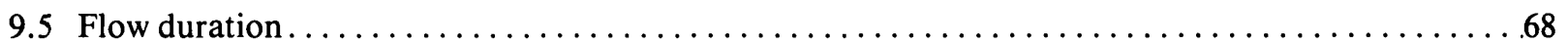

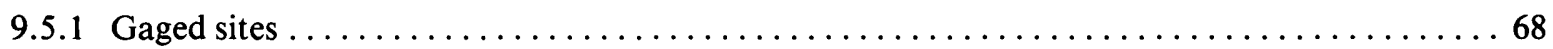

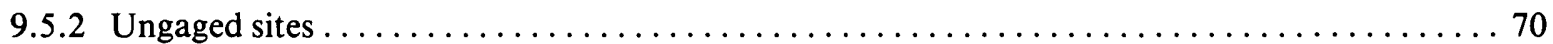

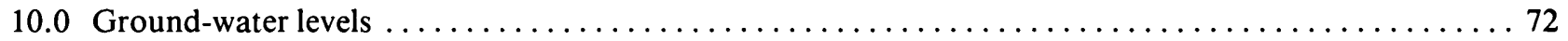

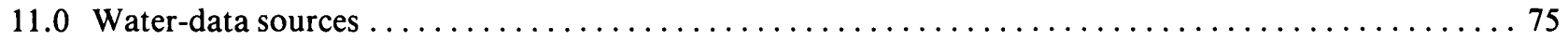

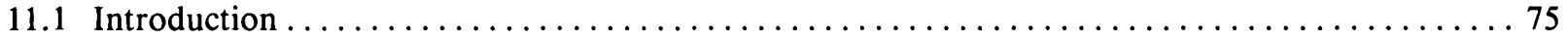

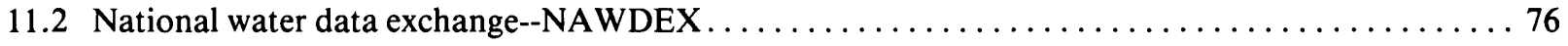

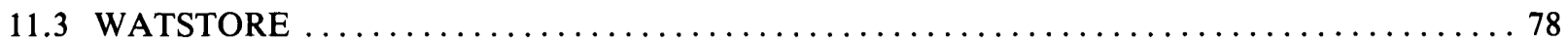

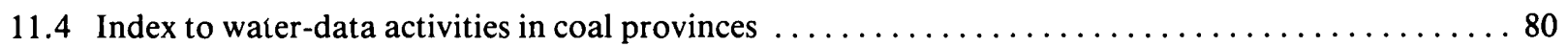

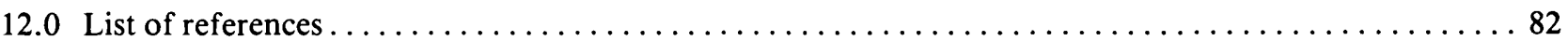

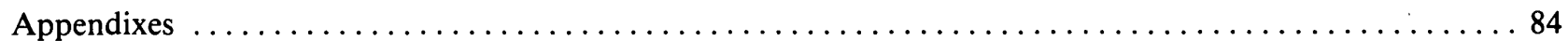

1. Station names and drainage areas for surface-water

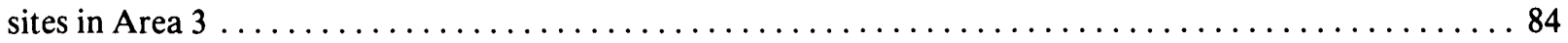

2. Numbers of taxonomic orders of benthic invertebrates

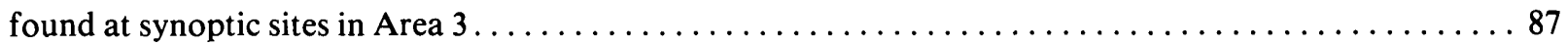




\section{FACTORS FOR CONVERTING INCH-POUND UNITS TO INTERNATIONAL SYSTEM OF UNITS (SI)}

For the convenience of readers who may want to use International System of Units (SI), the data may be converted by using the following factors:

Multiply inch-pound units

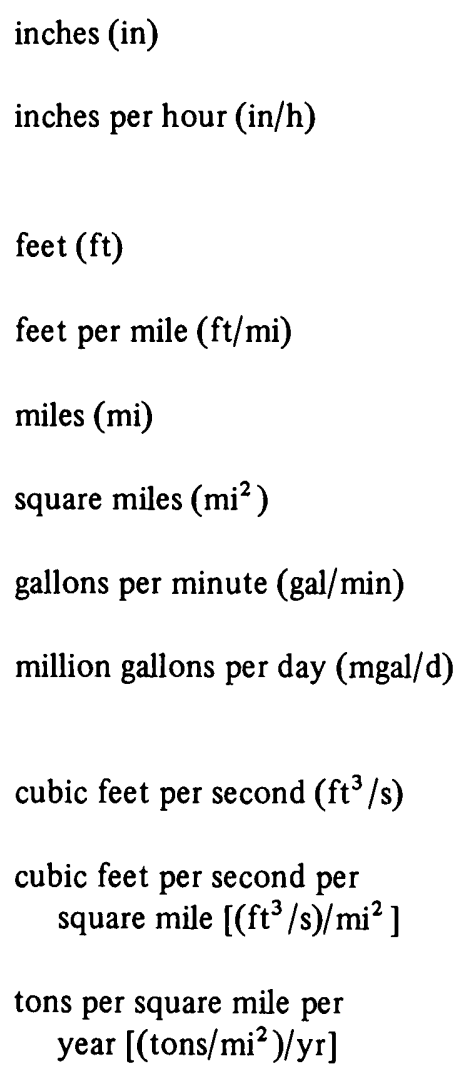

millimeters (mm)

millimeters per hour $(\mathrm{mm} / \mathrm{h})$ centimeters per hour $(\mathrm{cm} / \mathrm{h})$

meters (m)

meters per kilometer $(\mathrm{m} / \mathrm{km})$

kilometers (km)

square kilometers $\left(\mathrm{km}^{2}\right)$

liters per second $(\mathrm{L} / \mathrm{s})$

cubic meters per second $\left(\mathrm{m}^{3} / \mathrm{s}\right)$ cubic meters per day $\left(\mathrm{m}^{3} / \mathrm{d}\right)$

cubic meters per second $\left(\mathrm{m}^{3} / \mathrm{s}\right)$

cubic meters per second per square kilometer $\left[\left(\mathrm{m}^{3} / \mathrm{s}\right) / \mathrm{km}^{2}\right]$

metric tons per square kilometer per year $\left[\left(\mathrm{t} / \mathrm{km}^{2}\right) / \mathrm{a}\right]$ 



\begin{abstract}
The Eastern Coal Province is divided into 24 hydrologic reporting areas. The divisions are based upon hydrologic factors, location, size, and mining activity. Hydrologic units (drainage basins) or parts of units are combined to form each area. Area 3 is located in the northern part of the Eastern Coal Province in the lower Allegheny River basin and covers an area of 4,077 square miles.
\end{abstract}

ABSTRACT

Area reports are designed to be useful to mining companies, their consultants, and regulatory authorities by presenting information concerning existing hydrologic conditions and identifying additional sources of hydrologic information. The hydrology of the area is presented in the format of a brief text and accompanying illustration(s) on a single waterresource related topic.

Major streams in Area 3 in addition to the Allegheny River are the Kiskiminetas River and Redbank, Mahoning, Crooked, and Buffalo Creeks. Area 3 is in the Appalachian Plateau physiographic province. The rock types in the area are predominantly sandstone and shale containing thin beds of limestone and coal. The area has a humid continental type climate. Mean rainfall in the area ranges from 36 to 48 inches.

Area 3 is underlain by the Monongahela, Allegheny, Pottsville, and Conemaugh coal fields. The Conemaugh and Allegheny are the most extensive. Individual coals within the major fields vary in their chemical composition. Coal production in Area 3 counties increased from $46,200,000$ tons in 1974 to $53,000,000$ tons in 1977 , but dropped to about $50,000,000$ tons in 1978.

A special network was established to collect hydrologic data in coal-bearing areas. Seventy-three monitoring stations (synoptic sites) were established in Area 3. Water samples are collected at these sites two or three times annually. Samples are analyzed for specific conductance, $\mathrm{pH}$, acidity, alkalinity, dissolved and total iron, dissolved and total man- ganese, dissolved sulfate, residue on evaporation, and other properties. Similar samples are collected at six gaging stations 6 to 9 times annually. Streams indicating acid-mine drainage were most common in the Redbank and Blacklick Creek basins, and the Conemaugh and lower Kiskiminetas River basins. Sixteen of the 73 synoptic sites had pH, acidity-alkalinity, total iron, total manganese, and dissolved sulfate which all were indicative of acid-mine drainage. When all synoptic sites in Area 3 were considered, there was a close relationship between specific conductance and dissolved solids.

Sampling at other water-quality stations indicated that specific conductance, $\mathrm{pH}$, iron, manganese, and sulfate can show considerable variability from stream to stream, and with time for a single stream.

Of 64 streams sampled in Area 3, 11 contained no benthic invertebrates. An additional 13 sites had low benthic invertebrate diversity indices which is an indication of poor water quality. Low diversity indices were twice as common in the southern part of Area 3 when compared with the northern part.

Recent streamflow data have been collected at 32 continuous-record gaging stations, 3 crest-stage partial-record stations, and 6 low-flow partial-record stations in Area 3 in addition to 70 miscellaneous sites. Low-flow, mean-flow, peak-flow, and flowduration data are presented for gaging stations in Area 3. Techniques or sources of information are presented to enable estimates of these flow characteristics at ungaged sites.

Water levels in observation wells in Area 3 fluctuate throughout the year. Levels are generally lowest during September-November and highest during March-May. The U.S. Geological Survey can help to identify and improve access to existing water data via: the National Water Data Exchange, the National Water Data Storage and Retrieval System, and the Office of Water Data Coordination. 


\title{
1.0 INTRODUCTION \\ 1.1 Objective
}

\section{REPORT SUBMITTED IN RESPONSE TO PUBLIC LA W 95-87}

\author{
Existing hydrologic conditions and identification of \\ sources of hydrologic information are presented.
}

This report provides hydrologic information, using a brief text with an accompanying map, chart, graph, or other illustration for each of a series of water-resources-related topics. The summation of the topical discussions provides a description of the hydrology of the area. The information contained herein should be useful to surface mine owners, operators, and consulting engineers in the preparation of permit applications, and to regulatory authorities in appraising the adequacy of the applications.

A need for hydrologic information and analysis on a scale never before required nationally resulted when the "Surface Mining Control and Reclamation
Act of 1977" was signed into law as Public Law 95-87, August 3, 1977. This report broadly characterizes the hydrology of Area 3 in Pennsylvania (fig. 1.1-1). The hydrologic information presented or available through sources identified in this report, may be used in describing the hydrology of the "general area" of any proposed mine. Furthermore, it is expected that this hydrologic information will be supplemented by the lease applicant's specific site data as well as data from other sources, to provide a more detailed picture of the hydrology in the vicinity of the mine and the anticipated hydrologic consequences of the mining operation. 


\section{(1)}
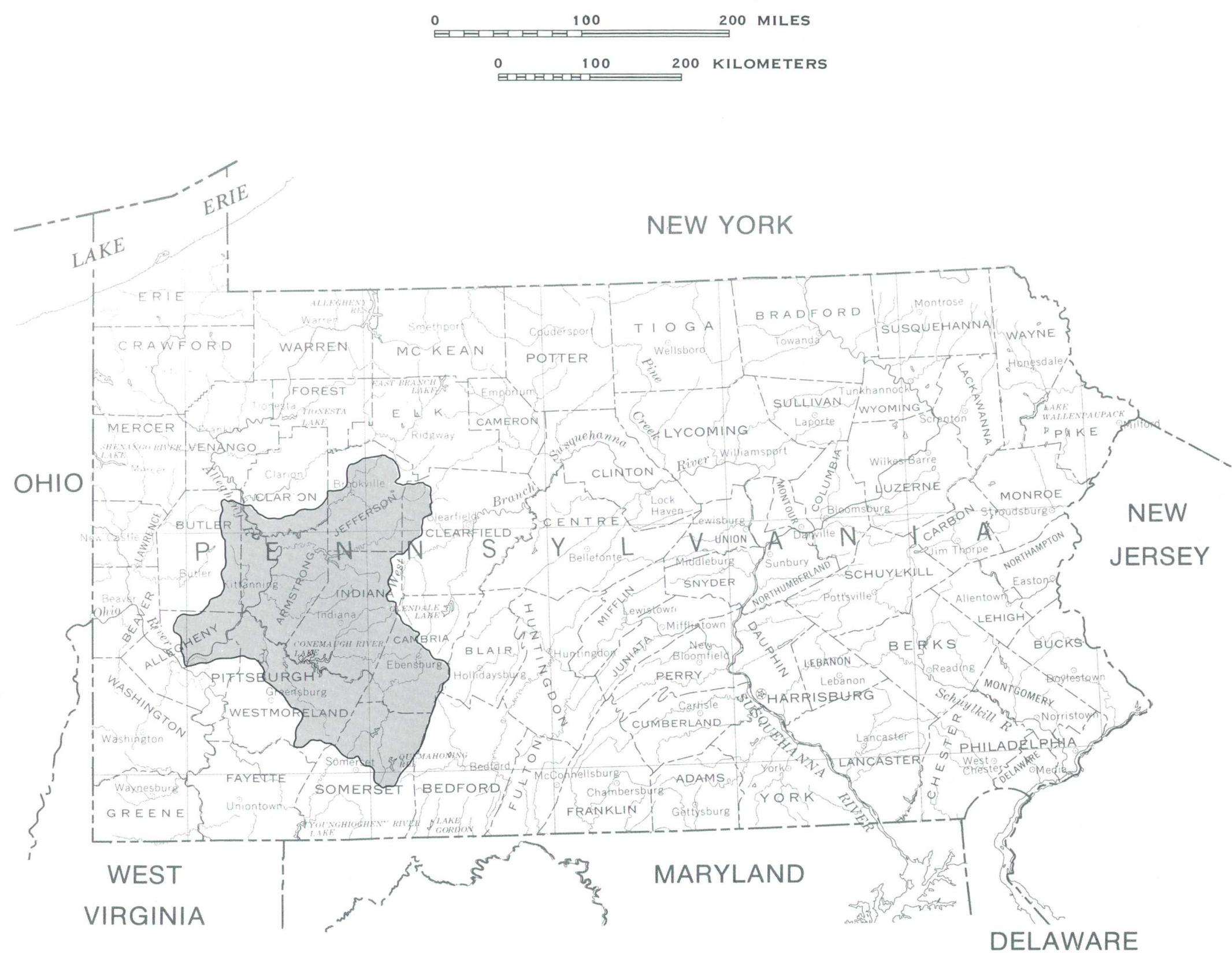

SCALE 1:750,000

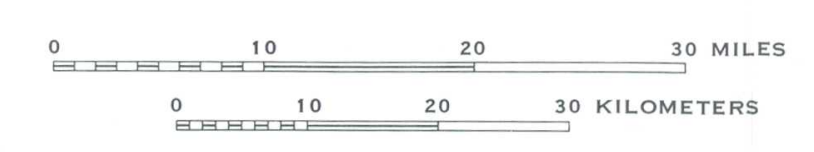

(1)

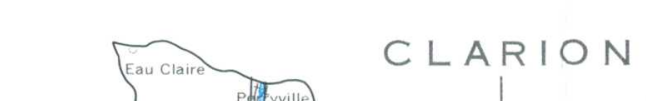

CLARION

BASE FROM U. S. GEOLOGICAL SURV
STATE BASE MAP

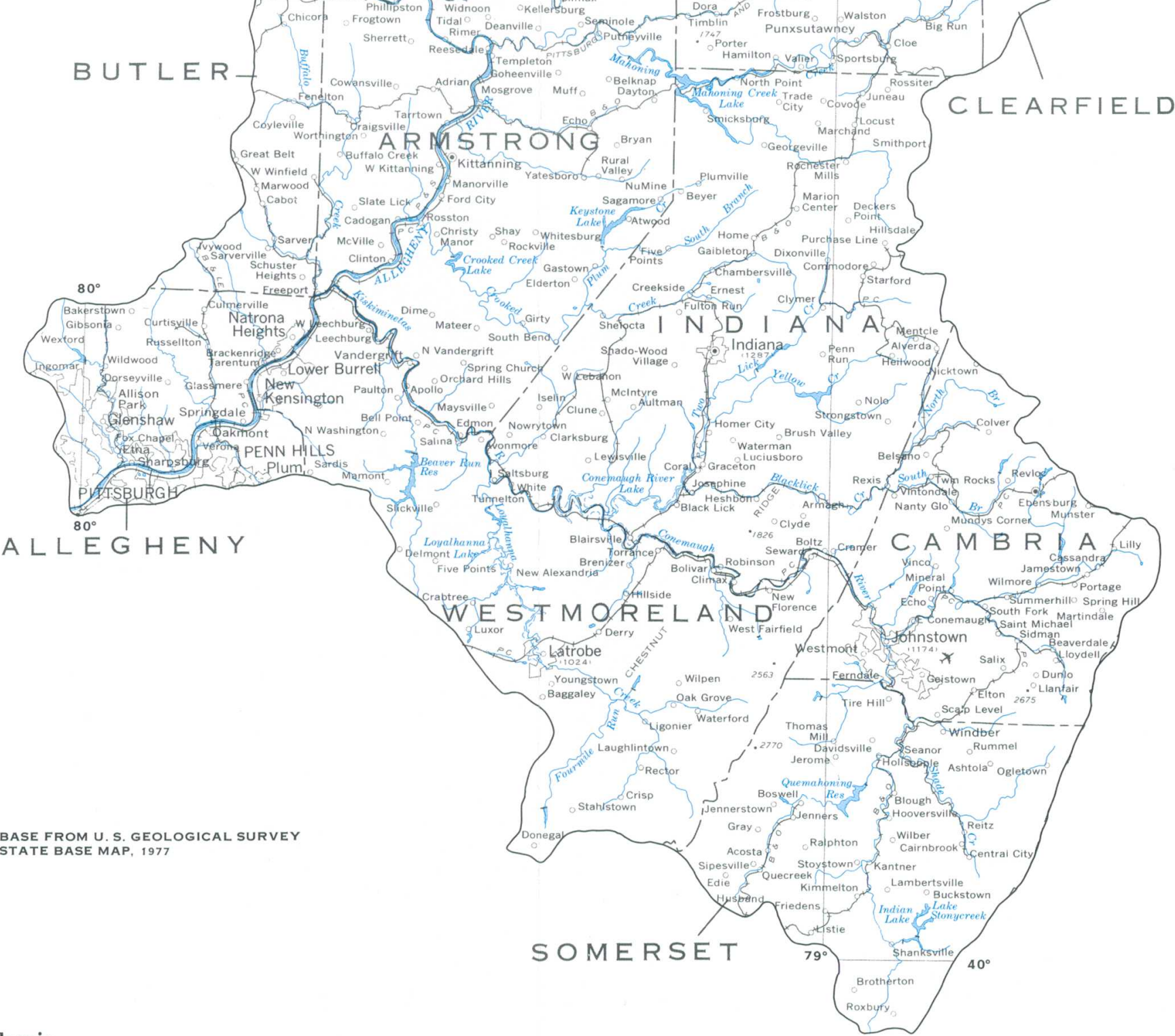




\subsection{INTRODUCTION (Continued) \\ 1.2 Project Area}

\section{HYDROLOGY AND WATER RESOURCES SUMMARIZED FOR AREA 3 IN PENNSYLVANIA}

\section{This report summarizes the hydrology and water resources of Area 3 in the northern part of the Eastern Coal Province in Pennsylvania.}

The Eastern Coal Province is divided into 24 hydrologic reporting areas. The division is based on hydrologic factors, location, size, and mining activity. Hydrologic units (drainage basins) or parts of units are combined to form each area (fig. 1.2-1) (see front cover for areas in the Eastern Coal Province).

Area 3 is near the northern end of the Eastern Coal Province in western Pennsylvania. The area, which includes part or all of Jefferson, Clearfield, Armstrong, Butler, Allegheny, Cambria, Indiana, Somerset, and Westmoreland Counties, lies within the Allegheny River basin, and includes parts of the
Monongahela, Allegheny, Pottsville, and Conemaugh Coal Fields.

The area encompasses the lower Allegheny River basin from Parker downstream to the Monongahela River at Pittsburgh. Major tributaries in the area are the Kiskiminetas River, Redbank, Crooked, Mahoning, and Buffalo Creeks. The surface area of Area 3 is 4,077 square miles. Surface drainage through Area 3 includes an additional drainage from 7,671 square miles of the Allegheny River basin. 
30 KILOMETERS

\begin{tabular}{rr}
$10 \quad 20$ \\
\hline
\end{tabular}

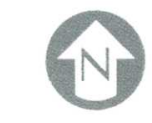

CLARION

$B \cup T L E R$
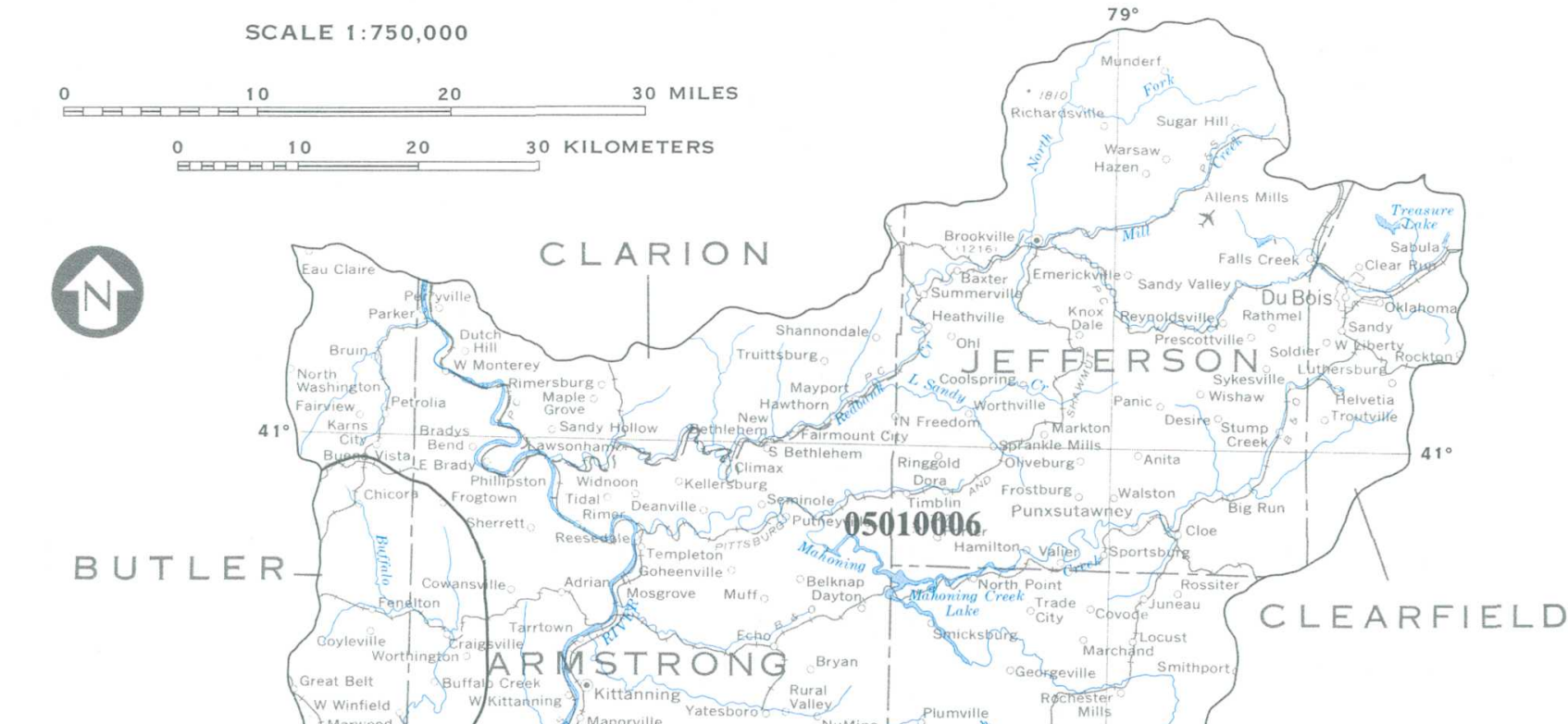

A L LEGHENY

BASE FROM U.S. GEOLOGICAL SURVEY STATE BASE MAP, 1977

Jut Kittanning Yatesborof valley
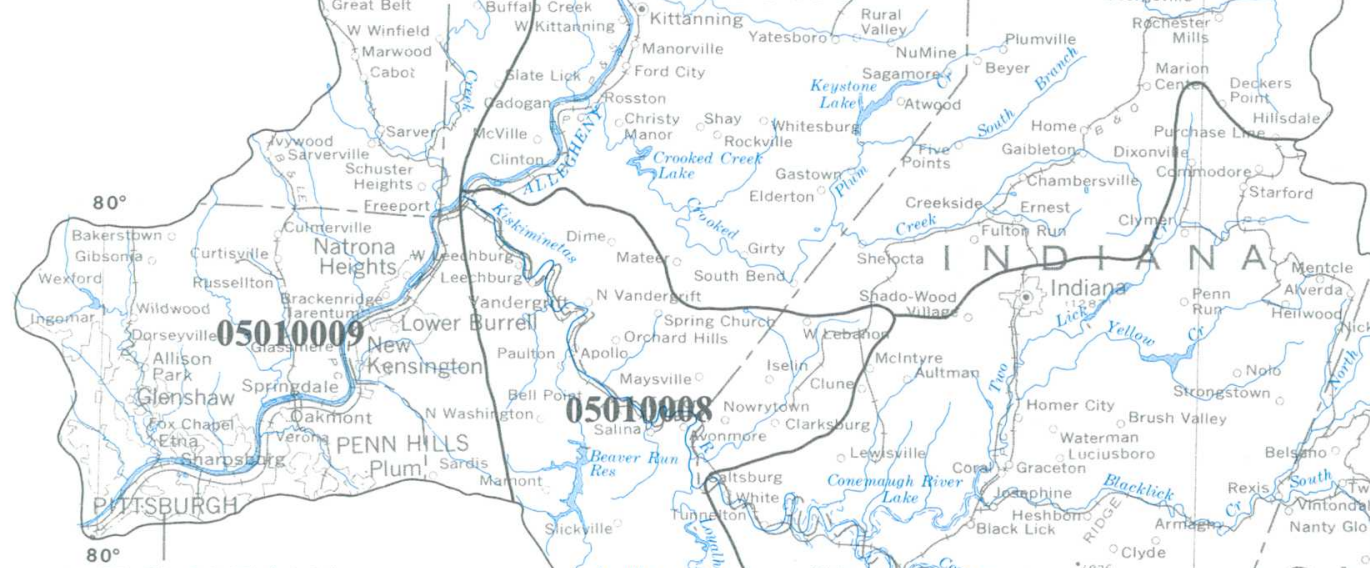

fadogar Lasston Christy Shay Whitesbur atwgód

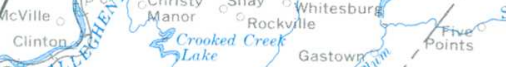

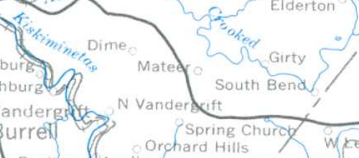

Paution Apolio o.

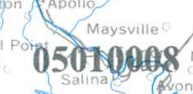

05010908 Nowryoun Clu
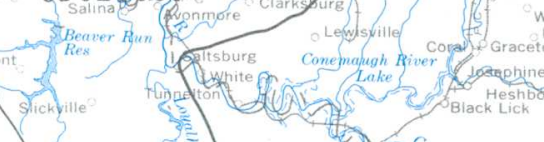

Ernest

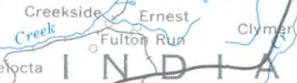

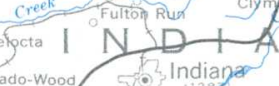
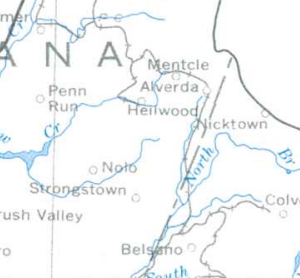

(a)

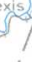
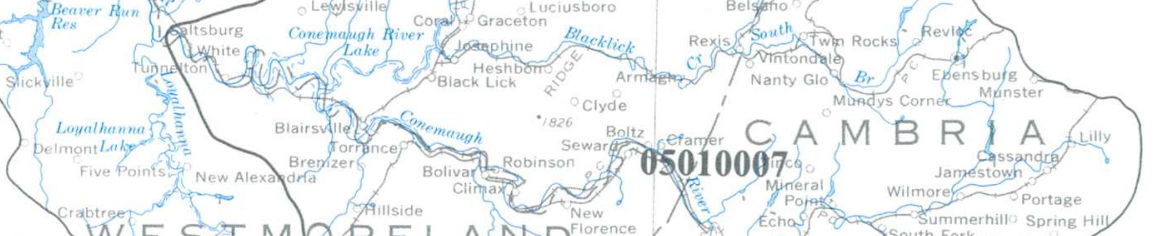

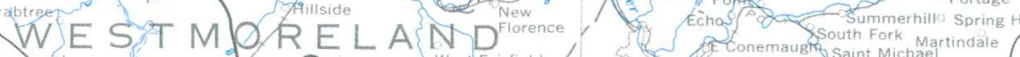

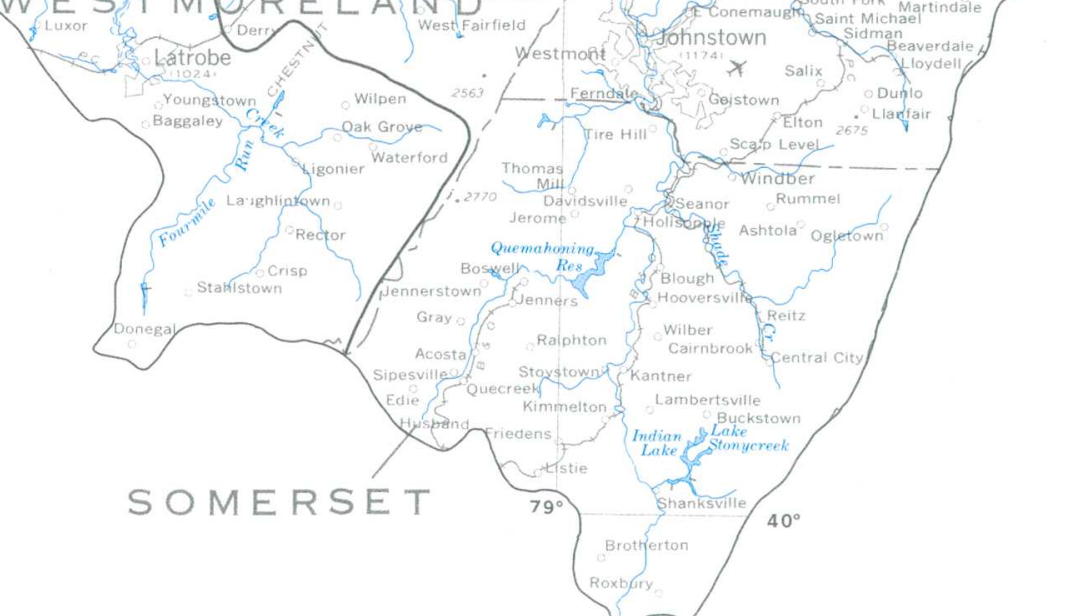

\section{EXPLANATION}

Hydrologic unit boundary

05010006 Hydrologic unit

Figure 1.2-1 Hydrologic units 


\title{
2.0 DEFINITION OF TERMS
}

\section{TERMS USED IN HYDROLOGIC REPORTS DEFINED}

\author{
Technical terms that occur in this \\ Hydrologic Report are defined.
}

Bed material is the unconsolidated material of which a streambed, lake, pond, reservoir, or estuary bottom is composed.

Benthic invertebrate, for this study, is an animal without a backbone, living on or near the bottom of an aquatic environment, which is retained on a 210 $\mu \mathrm{m}$ mesh sieve.

Bottom material specifically includes anthropogenic matter in addition to natural solid material in bed material.

Cubic feet per second per square mile $\left[\left(\mathrm{ft}^{3} / \mathrm{s}\right) \mathrm{mi}^{2}\right]$ is the average number of cubic feet of water flowing per second from each square mile of area drained, assuming that the runoff is distributed uniformly in time and area.

Cubic foot per second $\left(\mathrm{ft}^{3} / \mathrm{s}\right)$ is the rate of discharge representing a volume of 1 cubic foot passing a given point during 1 second and is equivalent to approximately 7.48 gallons per second or 448.8 gallons per minute or 0.02832 cubic meters per second.

Discharge is the volume of water (or more broadly, volume of fluid plus suspended material), that passes a given point within a given period of time.

Mean discharge is the arithmetic mean of individual daily mean discharges during a specific period.

Instantaneous discharge is the discharge at a particular instant of time.

Dissolved refers to the amount of substance present in true chemical solution. In practice, however, the term includes all forms of substance that will pass through a 0.45 -micrometer membrane filter, and thus may include some very small (colloidal) suspended particles. Analyses are performed on filtered samples.
Diversity index is a numerical expression of eveness of distribution of aquatic organisms, the formula is:

$$
\mathrm{d}=-\sum_{i=1}^{s} \frac{n_{i}}{n} \log _{2} \frac{n_{i}}{n}
$$

Where $n$ is the number of individuals per taxon, $n$ is the total number of individuals, and $s$ is the total number of taxa in the sample of the community. Diversity index values range from zero, when all the organisms in the sample are the same, to some postivie number, when some or all of the organisms in the sample are different.

Drainage area of a stream at a specific location is that area, measured in a horizontal plane, enclosed by a topographic divide from which direct surface runoff from precipitation normally drains by gravity into the river above the specified point. Figures of drainage area given herein include all closed basins, or noncontribution areas, within the area unless otherwise noted.

Drainage basin is a part of the surface of the Earth that is occupied by a drainage system, which consists of a surface stream or a body of impounded surface water together with all tributary surface streams and bodies of impounded surface water.

Gage height (G.H.) is the water-surface elevation referred to some arbitrary gage datum. Gage height is often used interchangeably with the more general term "stage", although gage height is more appropriate when used with a reading on a gage.

Gaging station is a particular site on a stream, canal, lake, or reservoir where systematic observations of hydrologic data are obtained.

Hydrologic unit is a geographic area representing part or all of a surface drainage basin or distinct hydrologic feature as delineated by the Office of 
Water Data Coordination on the State Hydrologic Unit Maps; each hydrologic unit is identified by an 8-digit number.

Micrograms per gram $(\mu \mathrm{g} / \mathrm{g})$ is a unit expressing the concentration of a chemical element as the mass (micrograms) of the element per unit mass (gram) of sediment.

Micrograms per liter $(\mu \mathrm{g} / \mathrm{L})$ is a unit expressing the concentration of chemical constituents in solution as mass (micrograms) of solute per unit volume (liter) of water. One thousand micrograms per liter is equivalent to one milligram per liter.

Milligrams per liter ( $\mathrm{mg} / \mathrm{L}$ ) is a unit for expressing the concentration of chemical constituents in solution. Milligrams per liter represent the mass of solute per unit volume (liter) of water. Concentration of suspended sediment also is expressed in $\mathrm{mg} / \mathrm{L}$, and is based on the mass (dry weight) of sediment per liter of water-sediment mixture.

Partial-record station is a particular site where limited streamflow and/or water-quality data are collected systematically over a period of years for use in hydrologic analyses.

Sediment is solid material that originates mostly from disintegrated rocks and is transported by, suspended in, or deposited from water; it includes chemical and biochemical precipitates and decomposed organic material, such as humus. The quantity, characteristics, and cause of the occurrence of sediment in streams are influenced by environmental factors. Some major factors are degree of slope, length of slope, soil characteristics, land usage, and quantity and intensity of precipitation.

Suspended sediment is the sediment that at any given time is maintained in suspension by the upward components of turbulent currents or that exists in suspension as a colloid.

Suspended-sediment concentration is the velocity-weighted concentration of suspended sediment in the sampled zone (from the water surface to a point approximately $0.3 \mathrm{ft}$ above the bed) expressed as milligrams of dry sediment per liter of watersediment mixture $(\mathrm{mg} / \mathrm{L})$.

Specific conductance is a measure of the ability of water to conduct an electrical current. It is expressed in micromhos per centimeter $(\mu \mathrm{mho} / \mathrm{cm})$ at $25^{\circ} \mathrm{C}$. Specific conductance is related to the type and concentration of ions in solution and can be used for approximating the dissolved-solids concentration of the water. Commonly, the concentration of dissolved solids (in milligrams per liter) is about 65 percent of the specific conductance (in micromhos). This relation is not constant from stream to stream, and it may vary in the same source with changes in the composition of the water.

Stage-discharge relation is the relation between gage height (stage) and volume of water per unit of time, flowing in a channel.

Streamflow is the discharge that occurs in a natural channel. Although the term "discharge" can be applied to the flow of a canal, the word "streamflow" uniquely describes the discharge in a surface stream course. The term "streamflow" is more general than "runoff" as streamflow may be applied to discharge whether or not it is affected by diversion or regulation.

Substrate is the physical surface upon which an organism lived.

Natural substrate refers to any naturally occurring emersed or submersed solid surface, such as a rock or tree, upon which an organism lived.

Taxonomy is the division of biology concerned with the classification and naming of organisms. The classification of organisms is based upon a hierarchical scheme beginning with Kingdom and ending with Species at the base. The higher the classification level, the fewer features the organisms have in common. For example, the taxonomy of a particular mayfly, Hexagenia limbata is the following:

$$
\begin{aligned}
& \text { Kingdom---Animal } \\
& \text { Phylum---Arthropoda } \\
& \text { Class---Insecta } \\
& \text { Order---Ephemeroptera } \\
& \text { Family---Ephemeridae } \\
& \text { Genus---Hexagenia } \\
& \text { Species---Hexagenia limbata }
\end{aligned}
$$




\title{
3.0 WATER QUALITY CRITERIA
}

\section{NEW REGULATIONS SET EFFLUENT LIMITATIONS FOR IRON, MANGANESE, PH, AND SUSPENDED SOLIDS}

\author{
Standards have been set for iron, manganese, \\ $\mathrm{pH}$, and suspended solids in water discharged \\ from areas disturbed by surface mining.
}

The Permanent Regulatory Program of the Office of Surface Mining sets specific standards for water leaving a mine site. Section 816.42 (a) (7) of the Permanent Regulatory Program states that "discharges of water from areas disturbed by surface mining shall be made in compliance with all Federal and State laws and regulations ...." This same section also sets certain specific numerical effluent limitations. The specific effluent limitations are for total iron, total manganese, total suspended solids, and pH. Table 3.0-1 lists these numerical standards.

The effluent limitations for iron and manganese are considerably higher than those recommended for drinking water by the U.S. Environmental Protection Agency which sets limits of $300 \mu \mathrm{g} / \mathrm{L}$ (micrograms per liter) iron and $50 \mu \mathrm{g} / \mathrm{L}$ manganese. 
Table 3.0-1 Mine effluent limitations. Effluent limitations in milligrams
per liter (mg/L) except for $\mathrm{pH}^{1}$

\begin{tabular}{|c|c|c|}
\hline $\begin{array}{l}\text { Effluent } \\
\text { Characteristics }\end{array}$ & $\begin{array}{l}\text { Maximum } \\
\text { allowable }\end{array}$ & $\begin{array}{l}\text { Average of daily } \\
\text { values for } 30 \\
\text { consecutive } \\
\text { discharge days }\end{array}$ \\
\hline Iron, total & 7.0 & 3.5 \\
\hline Manganese, total ${ }^{2}$ & 4.0 & 2.0 \\
\hline Total suspended solids & 70.0 & 35.0 \\
\hline $\mathrm{pH}^{3}$ & Within range of 6.0 to 9.0 & \\
\hline
\end{tabular}




\title{
AREA IS IN APPALACHIAN PLATEAUS PHYSIOGRAPHIC PROVINCE AND IS UNDERLAIN BY SANDSTONES AND SHALES
}

\author{
Area 3 is in the Unglaciated Allegheny Plateau \\ and Allegheny Moutain Sections of the \\ Appalachian Plateaus physiographic province. \\ Primary rock types in the Area are sandstones and shales.
}

\begin{abstract}
Eastern Coal Province Area 3 is in the Unglaciated Allegheny Plateau and Allegheny Mountain Sections of the Appalachian Plateaus physiographic province (Fenneman, 1938). In the Allegheny Mountain section the rocks are mildly folded and many of the mountains are plateau-like, and are separated by strips of deeply dissected plateau. The Unglaciated Allegheny Plateau is characterized by low, broad ridges, although there are many valleys with relief of several hundred feet.
\end{abstract}

Rock types in Eastern Coal Province Area 3 are primarily sandstone and shale that contain thin beds of limestone and coal. The rocks dip only a few degrees to the northwest or southeast on the flanks of broad folds that are about 10 miles across.

The rocks are divided into six stratigraphic units, four in the Pennsylvanian System and two in the Mississippian System. The stratigraphic order of the rock units, from youngest to oldest, are the Monon- gahela Formation, Conemaugh Formation, Allegheny Group, and Pottsville Group of Pennsylvanian age; and the Mauch Chunk Formation and Pocono Group of Mississippian age. Coal beds and limestone are common in the Pennsylvanian System (Pennsylvania Topographic and Geologic Survey, 1960).

The Conemaugh Formation is the most areally extensive stratigraphic unit and the Allegheny Group is the second most extensive (fig. 4.1-1). The Pottsville and Pocono Groups are about equal in size and are limited to the northern and southern parts of the area. The Monongahela Formation is fifth in areal extent and is found in the southwestern one-third of the area. The Mauch Chunk Formation is the least extensive stratigraphic unit and is in the southern section of the area. The Mauch Chunk Formation generally is found between the Pottsville and Pocono Groups (fig. 4.1-1). 
산
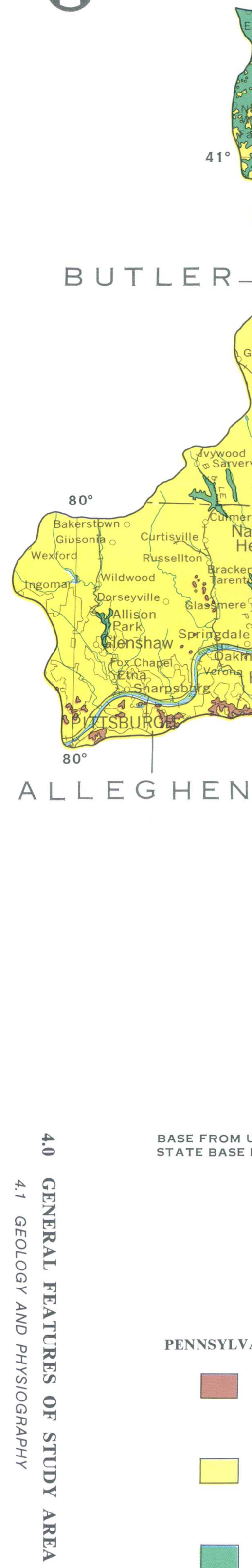

A L LE G H N Y

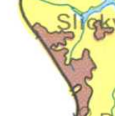

PENNSYlVANia APPAlachian PlateaU

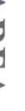

\section{CLARION}

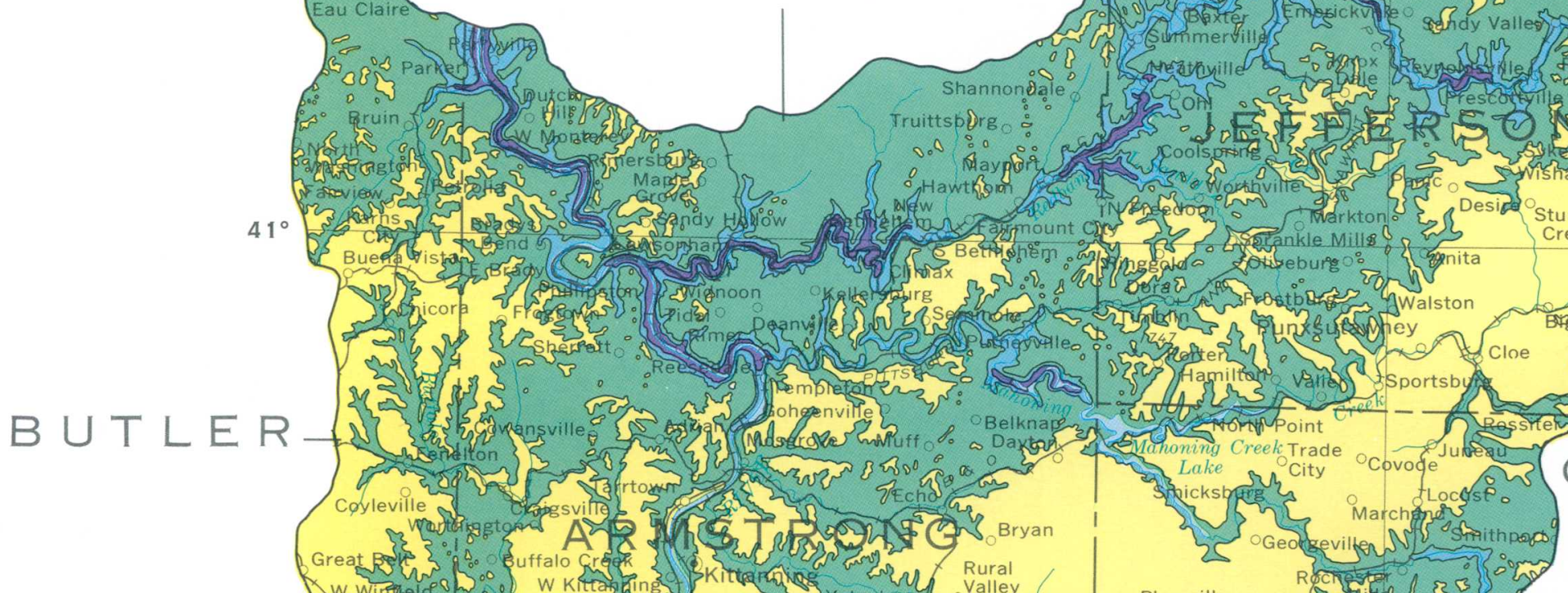

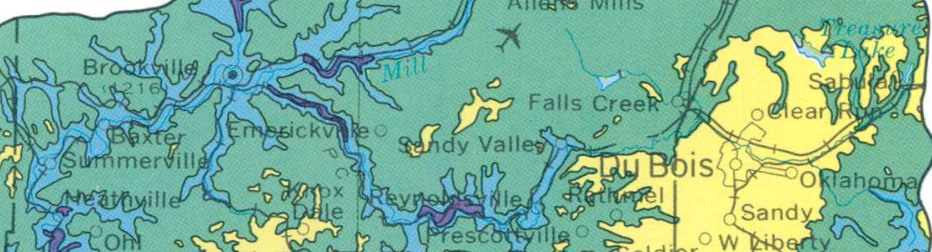
diter w wandy

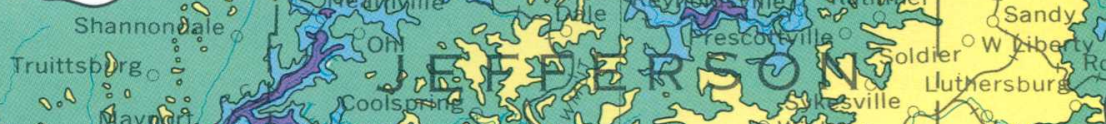

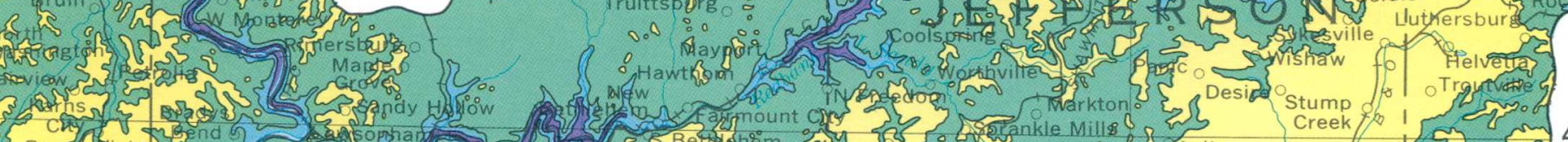
$41^{\circ}$

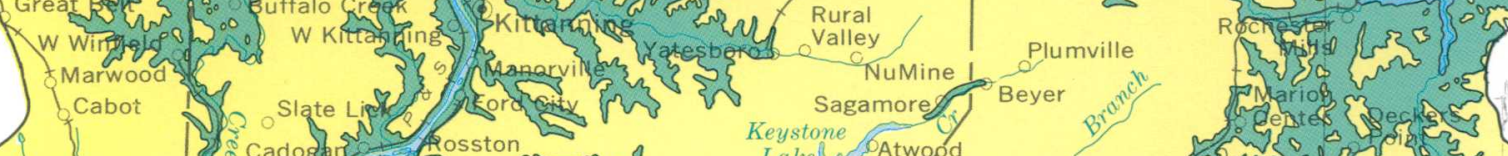

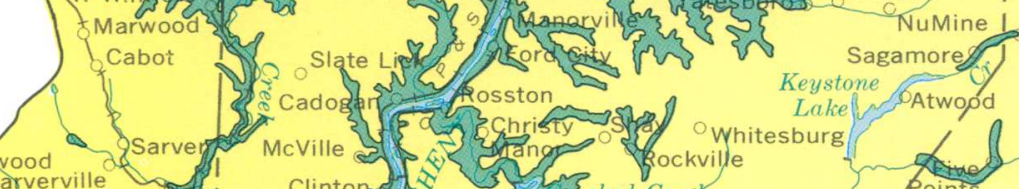

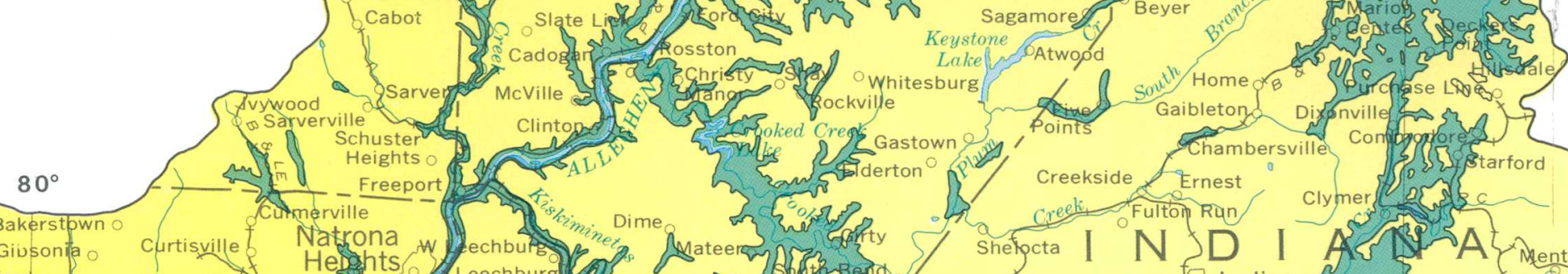

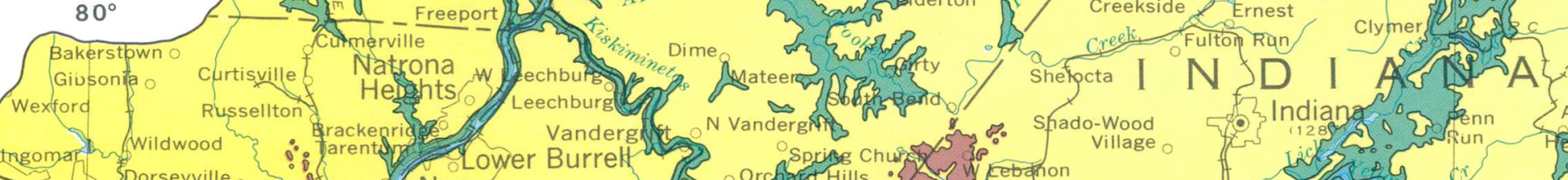

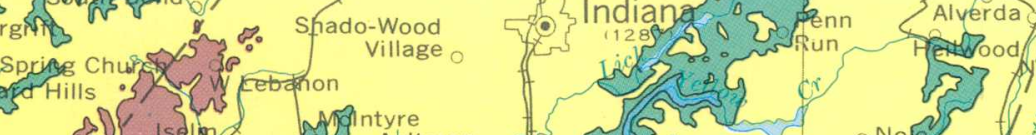

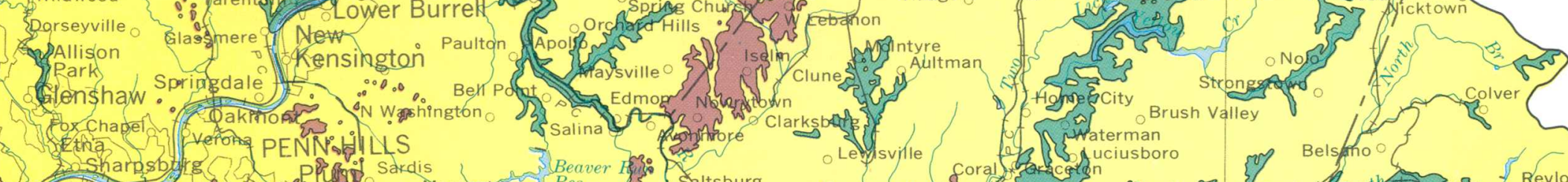

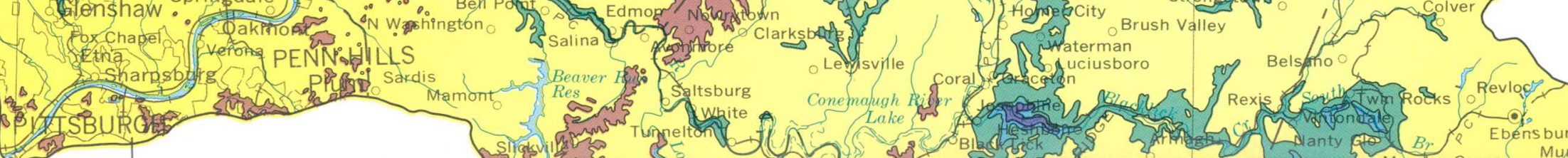

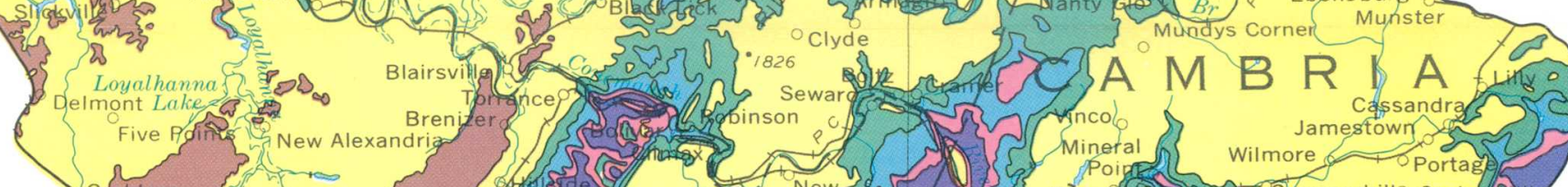

SOMERSET

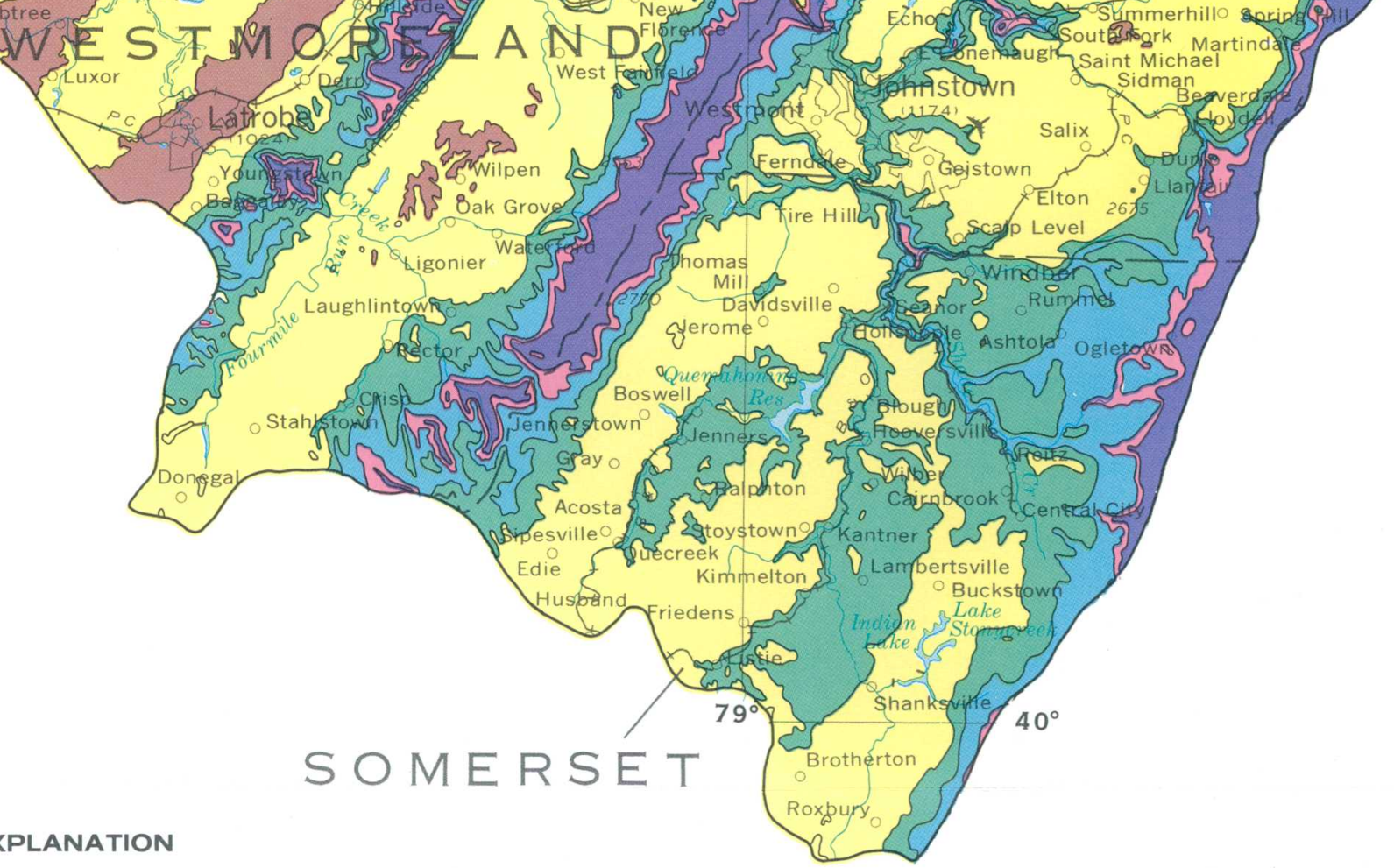

MISSISSIPPIAN

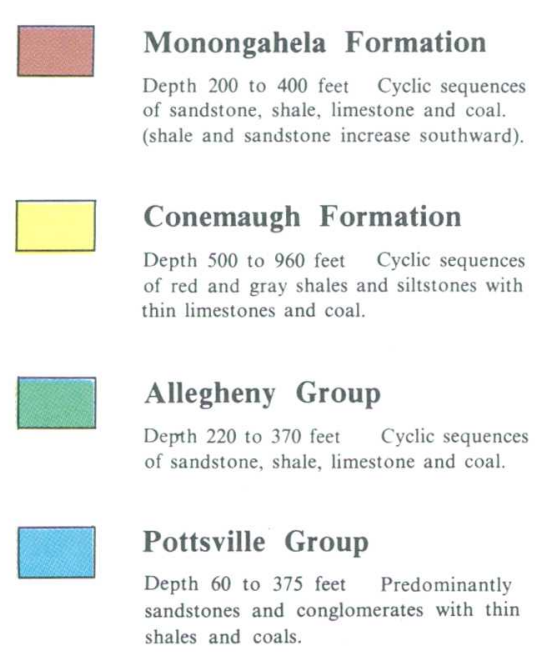

Pocono Group

Depth 20 to 60 feet Predominantly gray.

hard, massive, cross-bedded conglomerace
and sandstone with some shale.

Mauch Chunk Formation

Depth 50 to 100 feet Red shales with

rown to greenish grey flaggy sandstones 


\title{
4.0 GENERAL FEATURES OF STUDY AREA (Continued) \\ 4.2 Surface Drainage
}

\section{FIVE MAJOR TRIBUTARIES DRAIN MORE THAN 80 PERCENT OF THE AREA}

\author{
Major tributaries of the Allegheny River draining \\ Area 3 are the Kiskiminetas River, Redbank Creek, \\ Mahoning Creek, Crooked Creek, and Buffalo Creek. \\ These tributaries drain more than 80 percent of the Area.
}

\begin{abstract}
Eastern Coal Province Area 3 consists of 4,077 $\mathrm{mi}^{2}$ (square miles) of the lower Allegheny River basin from Parker downstream to the Monongahela River at Pittsburgh. Five major tributaries drain over 80 percent of Area 3 (fig. 4.2-1). East of the Allegheny River the Kiskiminetas River, Redbank Creek, Mahoning Creek, and Crooked Creek have drainage areas of $1,877,573,425$, and $292 \mathrm{mi}^{2}$, respectively. The major tributary west of the Allegheny is Buffalo Creek, which has a drainage area of $171 \mathrm{mi}^{2}$. The
\end{abstract}

remaining $729 \mathrm{mi}^{2}$ in Area 3 is drained directly by the Allegheny River or by various smaller tributaries.

The Kiskiminetas River drains the southeast 46 percent of Area 3. Major tributaries of the Kiskiminetas River are Stony Creek, Blacklick Creek, and Loyalhanna Creek having drainage areas of 467 , 418, and $299 \mathrm{mi}^{2}$, respectively. The Conemaugh River becomes Kiskiminetas River downstream from Loyalhanna Creek. 
SCALE $1: 500,000$
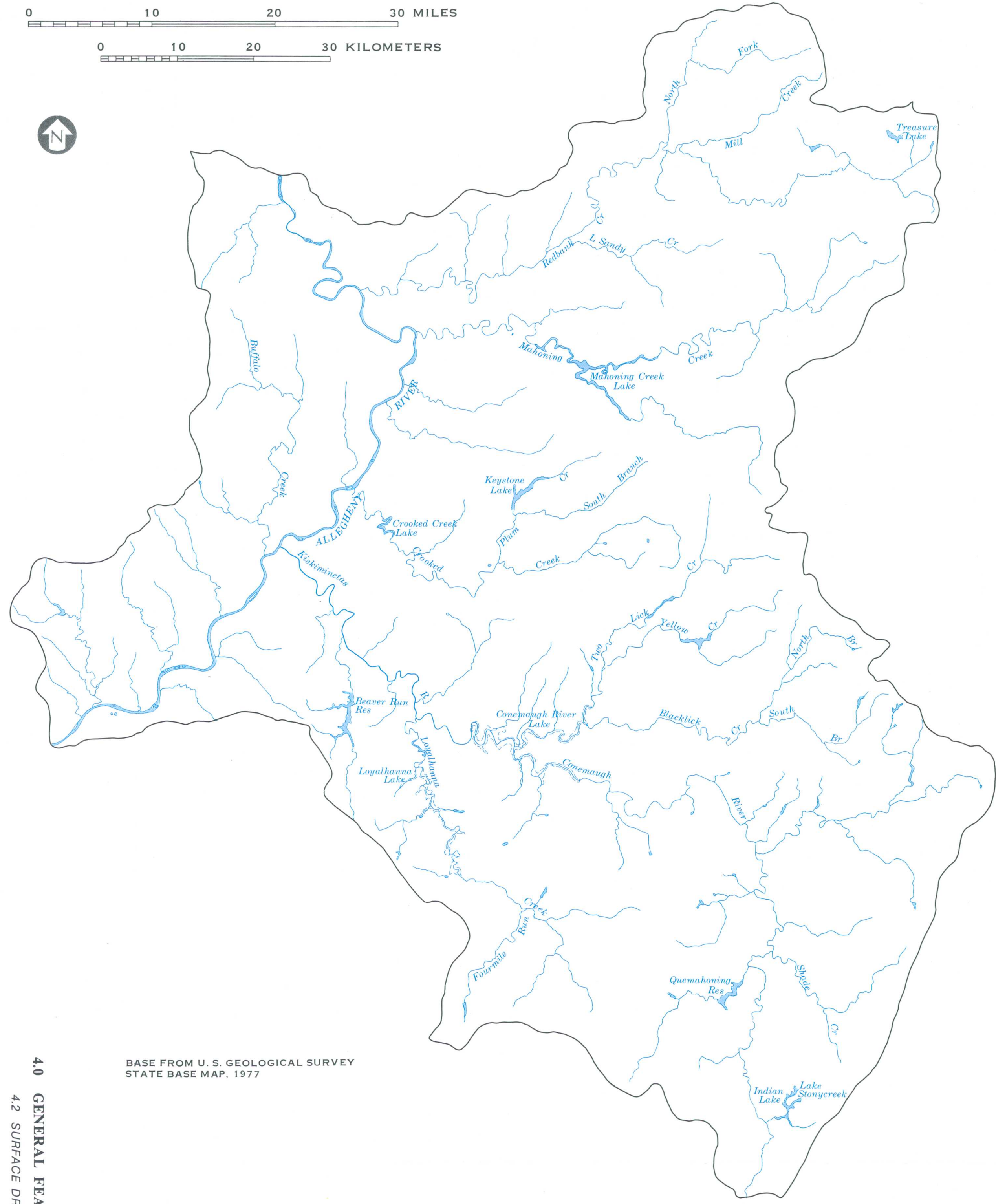

Figure 4.2-1 Major streams 


\title{
4.0 GENERAL FEATURES OF STUDY AREA (Continued) \\ 4.3 Soils
}

\section{SOILS IN THE AREA ARE MODERATELY ACIDIC TO NEUTRAL AND ARE GENERALLY SUITABLE FOR PLANT GROWTH}

\author{
Soil $\mathrm{pH}$ levels generally range from 5.0 to $7.0 \mathrm{in}$ \\ Area 3. Some soil associations have been reported \\ to have $\mathrm{pH}$ levels as low as 4.6, but most are suitable \\ as a plant growth medium for disturbed land reclamation.
}

Most of the soils in Eastern Coal Province Area 3 have $\mathrm{pH}$ levels in the 5.0 to 7.0 range. Several soil associations, the Gilpin-Clymer-Cookport, HazletonCookport, and the Hazleton-Gilpin-Ernest, have had minimum pH levels of 4.6 reported. Table 4.3-1 presents features of the 11 soil associations found in Area 3.

The map presented in figure 4.3-1, showing the location of the soil associations in Area 3, and the data in table 4.3-1 are very general. A soil association is a landscape that has a distinctive proportional pattern of soils (U.S. Department of Agriculture, 1968b). More detailed information for individual counties within the area is available from the U.S. Soil Conservation Service.

Soils in Area 3 are generally suitable as a plant growth medium for disturbed land reclamation. Most soils would receive a "good" or "fair" rating when using the criteria in table 4.3-2 for $\mathrm{pH}$, coarse fragment, available water capacity, depth to bedrock, and slope categories. 


\begin{tabular}{|c|c|c|c|}
\hline \multicolumn{3}{|c|}{ 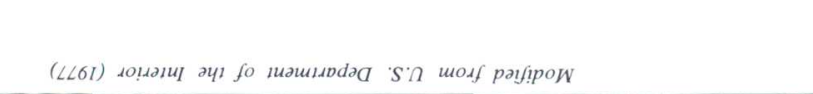 } & 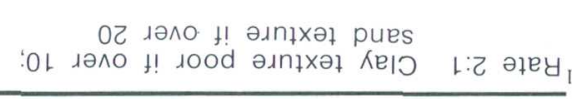 \\
\hline 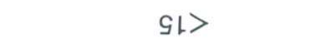 & st-8 & 8> & (१uәว.әd) ədo|S \\
\hline sәчәи! 0z> & səuэu! 0t-0z & səyəu! $0 t<$ & 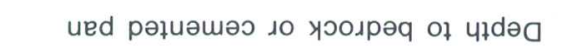 \\
\hline so $0>$ & so.0-เ०0 & $10<$ & 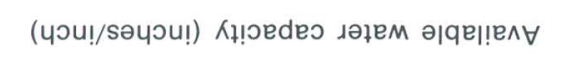 \\
\hline әsıео & әи!! & 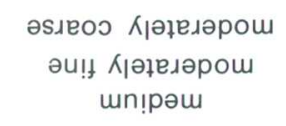 & 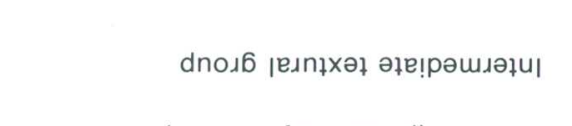 \\
\hline$\varsigma \varepsilon<$ & sE-GL & st> & 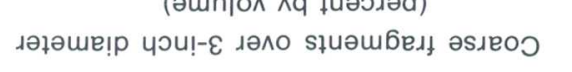 \\
\hline$\varsigma^{\prime} 8<\varsigma^{\prime} \varepsilon>$ & $0 . \varsigma-\varsigma^{\prime} \varepsilon$ & $g \circ 8-0,9$ & $\mathrm{Hd}^{\mathrm{a}}$ \\
\hline 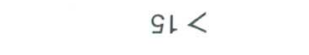 & sL-Z & $z>$ & 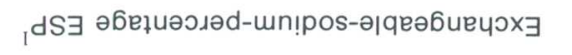 \\
\hline $\mathrm{zl}<$ & $2 \mathrm{~L}-\mathrm{z}$ & ¿> & 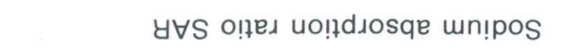 \\
\hline $91<$ & $9 \mathrm{9l-8}$ & 8> & 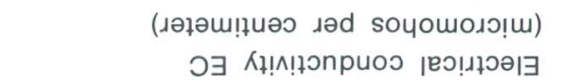 \\
\hline $\begin{array}{c}\text { (ә|qe)!nsun Kile!!uassa } \\
\text { yoOd }\end{array}$ & yit & 0009 & 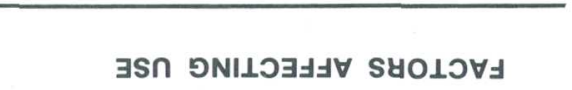 \\
\hline 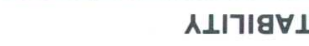 & $s$ s0 $\exists \exists y_{0}$ & & \\
\hline
\end{tabular}

\begin{tabular}{|c|c|c|c|c|c|c|c|}
\hline & & & & & & Бәсен6 & \\
\hline $8-0$ & $92^{\circ}-05^{\circ}$ & $\varepsilon^{\prime} 9-z^{\prime} 0$ & $0<-0,9$ & $01-\varepsilon$ & s૬-9ع & 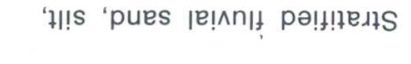 & 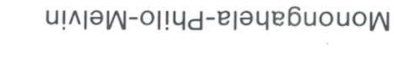 \\
\hline $0 z-\varepsilon$ & S2'-GL' & $0 \cdot z-2 \cdot 0>$ & $9 \cdot 9-0 \cdot 9$ & $9-\varepsilon$ & zt & 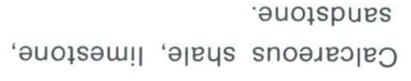 & 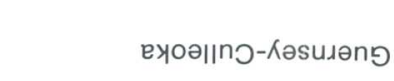 \\
\hline $0 z-\varepsilon$ & s2'-s0' & $\varepsilon \cdot 9-z^{\prime} 0>$ & $0<-0 \cdot 9$ & $0 z-2 / L \mathrm{~L}$ & $99-8$ & 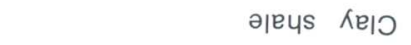 & 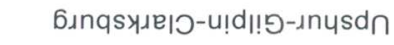 \\
\hline $0 z-0$ & $s Z^{\prime}-s 0^{\circ}$ & $\varepsilon \cdot 9-2 \cdot 0>$ & $s: s-0 \cdot s$ & $9-2 / 1 / 1$ & $8 t-0 \varepsilon$ & 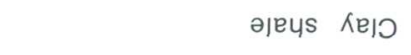 & u!d!!פ-иониечМ-әролеЈ \\
\hline $0 z-0$ & SZ'-st' & $\varepsilon \cdot 9-2 \cdot 0>$ & $G: G-0 \cdot s$ & $0 z-\varepsilon$ & $09-8 t$ & 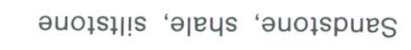 & 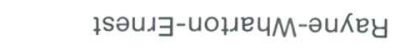 \\
\hline $0 z-0$ & $s Z^{\prime}-s 0^{\circ}$ & $\varepsilon 9-z^{\prime} 0$ & $\tau \cdot 9-9 \cdot t$ & $0 z-2 / 1$, & $09-9 \varepsilon$ & 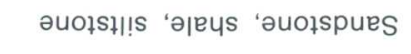 & 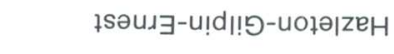 \\
\hline $0 z-0$ & $0 z^{\prime}-2 t^{\prime}$ & $\varepsilon^{\prime} 9-z^{\prime} 0$ & $z \cdot 9-9 \cdot t$ & $t-2 / 2$ & $6 \varepsilon$ & 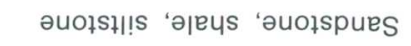 & 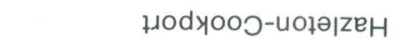 \\
\hline $0 t-\varepsilon$ & $\mathrm{s} \mathrm{z}^{-} \mathrm{s} 0^{\circ}$ & $\varepsilon \cdot 9-z^{\prime} 0>$ & $0 \angle-0 \cdot G$ & $9-t$ & $9 \varepsilon-8$ & 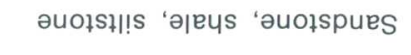 & นәу|əM-Іnusdn-u!d!! \\
\hline $0 z-0$ & $\varsigma Z^{\prime}-\varsigma 0^{\circ}$ & $\varepsilon^{\prime} 9-z^{\prime} 0$ & $s \cdot s-0 \cdot s$ & $0 z-2 / 1$ & $09-9 \varepsilon$ & 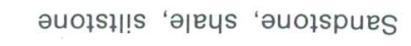 & иодечмМ-ısәuџэ-и!d!! \\
\hline $0 z-\varepsilon$ & SL'-so' & $\varepsilon \cdot 9-0 \cdot 2$ & $s \cdot s-0, s$ & $t-2 / 1$, & $9 \varepsilon-0 \varepsilon$ & әиоłsł!!s 'ә|ечs 'әuоłspues & 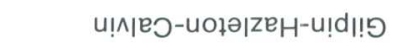 \\
\hline $0 z-0$ & $02^{-}-\mathrm{so}$ & $\varepsilon \cdot 9-z^{\circ} 0$ & $z \cdot 9-9 \cdot t$ & $3 / \mathrm{t}-2=2 / \mathrm{L}$ & $6 \varepsilon-9 \varepsilon$ & әиоłsㄴ‼s 'әرечs 'әuоłspues & 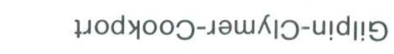 \\
\hline$s z-\varepsilon$ & st $-90^{\circ}$ & $\varepsilon 9-0 \tau$ & $\mathrm{g}: \mathrm{s}-0 \mathrm{~s}$ & $t-2$ & $0 \varepsilon$ & 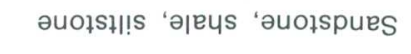 & 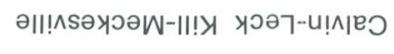 \\
\hline (दuәәдәd) & (Чכั!/sə૫ગu!) & (Аnoч/ Sə૫วu!) & & 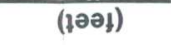 & ('әөчวи!) & $\forall \perp \forall \forall \perp$ Sans & NOILVIDOSS $\forall$ 7IOS \\
\hline 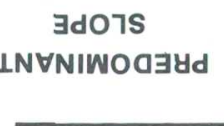 & 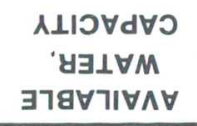 & 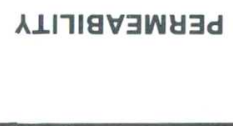 & $H^{d}$ & 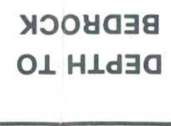 & 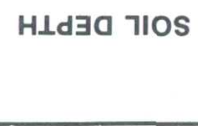 & & \\
\hline
\end{tabular}

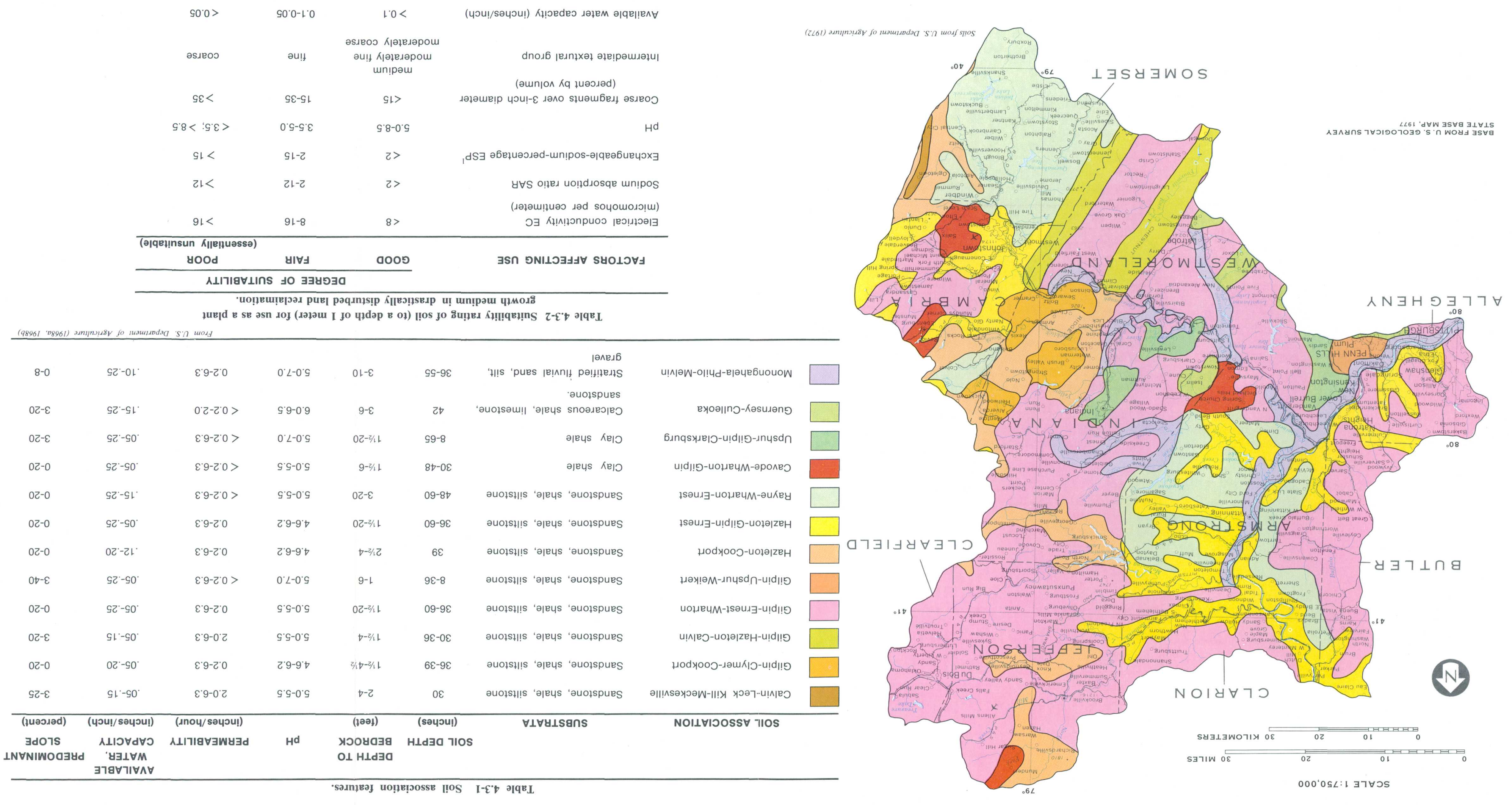




\title{
4.0 GENERAL FEATURES OF STUDY AREA (Continued) \\ 4.4 Climate
}

\section{AREA HAS HUMID CONTINENTAL TYPE CLIMATE WITH ANNUAL PRECIPITATION OF 36 TO 48 INCHES}

\author{
The humid continental type climate of Area 3 \\ is greatly influenced by the large number of \\ storm tracks that cross the area. Mean \\ annual precipitation in the Area ranges from \\ 36 to 48 inches.
}

Area 3 is located in the Allegheny Mountains and its western foothills, and has a humid continental type climate. A number of major storm tracks cross the area and enter from the north, west, and south. Winter storms originate in polar Canada and travel due south from the Hudson Bay or east from the Rocky Mountains. In the winter warm air from the Gulf sometimes travels north causing alternate thawing and freezing. Snow usually begins in late November and ends in early April. The amount of snow varies with elevation and usually covers the ground an average of 33 days during the year. Rain is distributed fairly evenly throughout the year, although March to September are the wettest months. Summer storms from the south bring heavy rains or hot, humid weather. Temperatures peak during July, usually one of the wettest months. Thunderstorms increase after the winter months, peak in midsummer, and become less frequent as the colder months begin. Mean annual precipitation ranges from 36 inches in the Western foothills to 48 inches in the mountains.

Mean annual precipitation, in inches, is shown by the isohyets on figure 4.4-1; the base period is
1941-70. The monthly normals and extremes at two weather stations are shown in figure 4.4-2. The maximums and minimums vary above and below the normal for each month. Monthly extremes of snowfall and ice pellets are illustrated in figure 4.4-3.

The average annual temperature for the study area is about $50^{\circ}$ to $55^{\circ} \mathrm{F}$. Temperatures have been recorded as high as $105^{\circ} \mathrm{F}$ during the month of July and as low as $-25^{\circ} \mathrm{F}$ in the month of January. Because of the change in topography, the mean annual freeze-free period ranges from 106 to 183 days. The recorded normals and extremes at the Pittsburgh Airport and Johnstown weather stations are shown in figure 4.4-4. The maximums and minimums vary above and below the normal for each month.

Daily precipitation data are published monthly as "Local Climatological Data for Pennsylvania" by the National Oceanic and Atmospheric Administration, National Climatic Center, Ashville, North Carolina. Statistical information concerning analysis and data are presented by U.S. Department of Commerce (1973). 


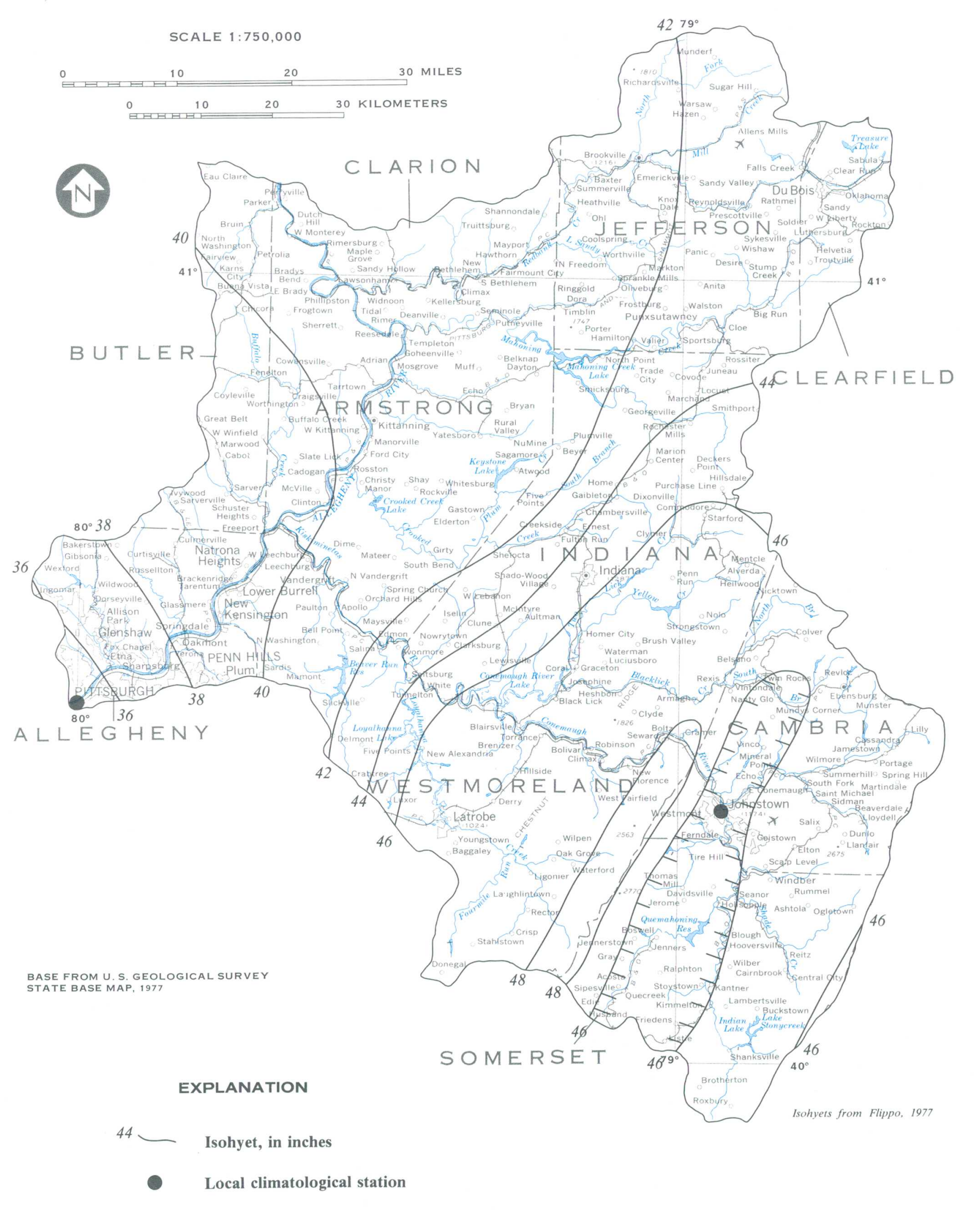

Figure 4.4-1 Mean annual precipitation.

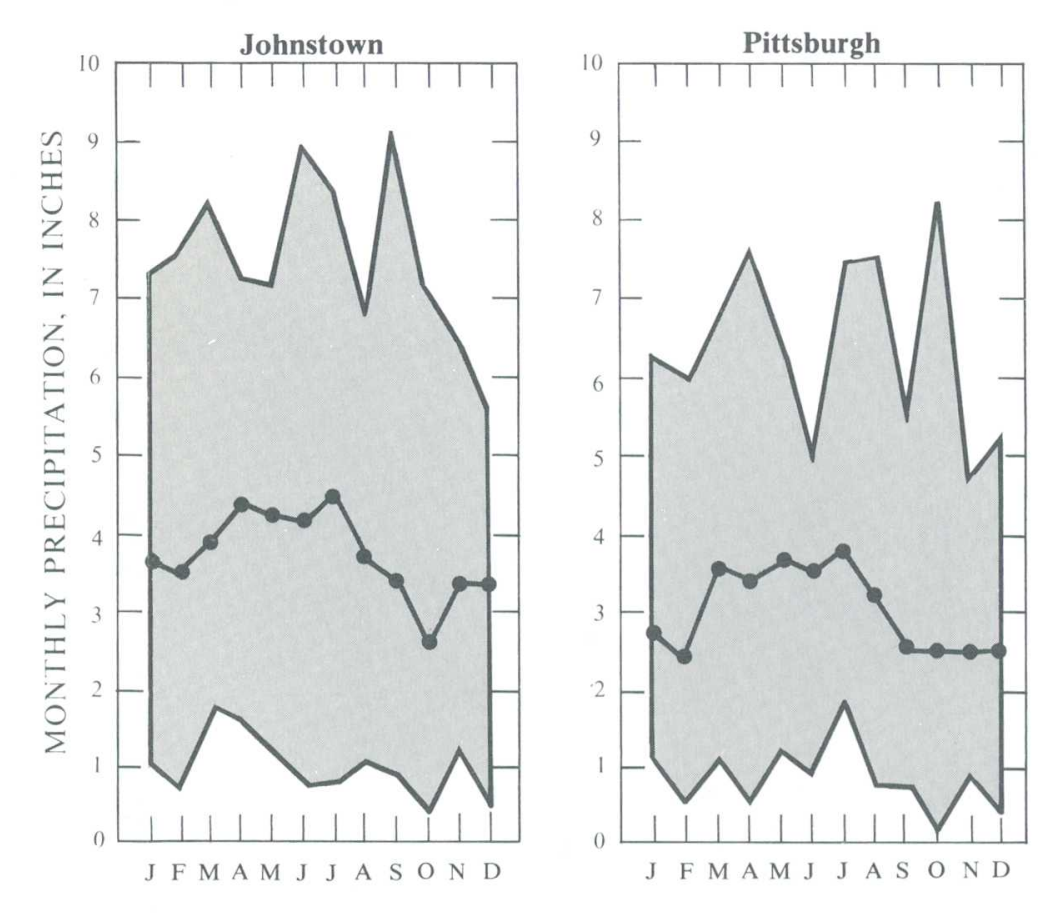

Figure 4.4-2 Monthly precipitation variation.

EXPLANATION

Range

$\leftrightarrow$ Mean
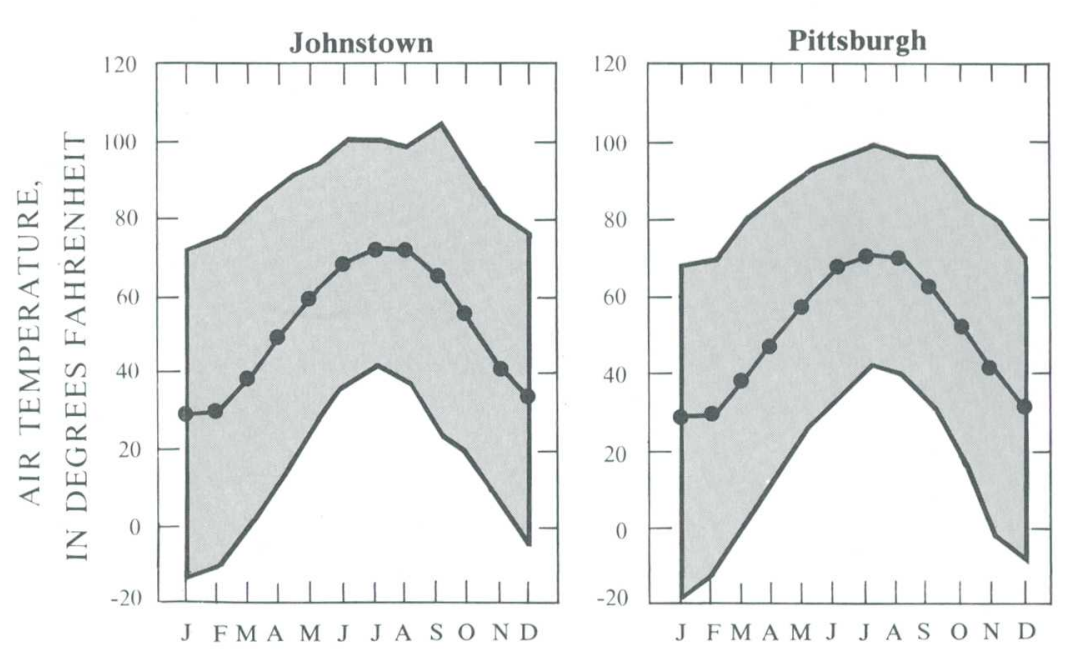

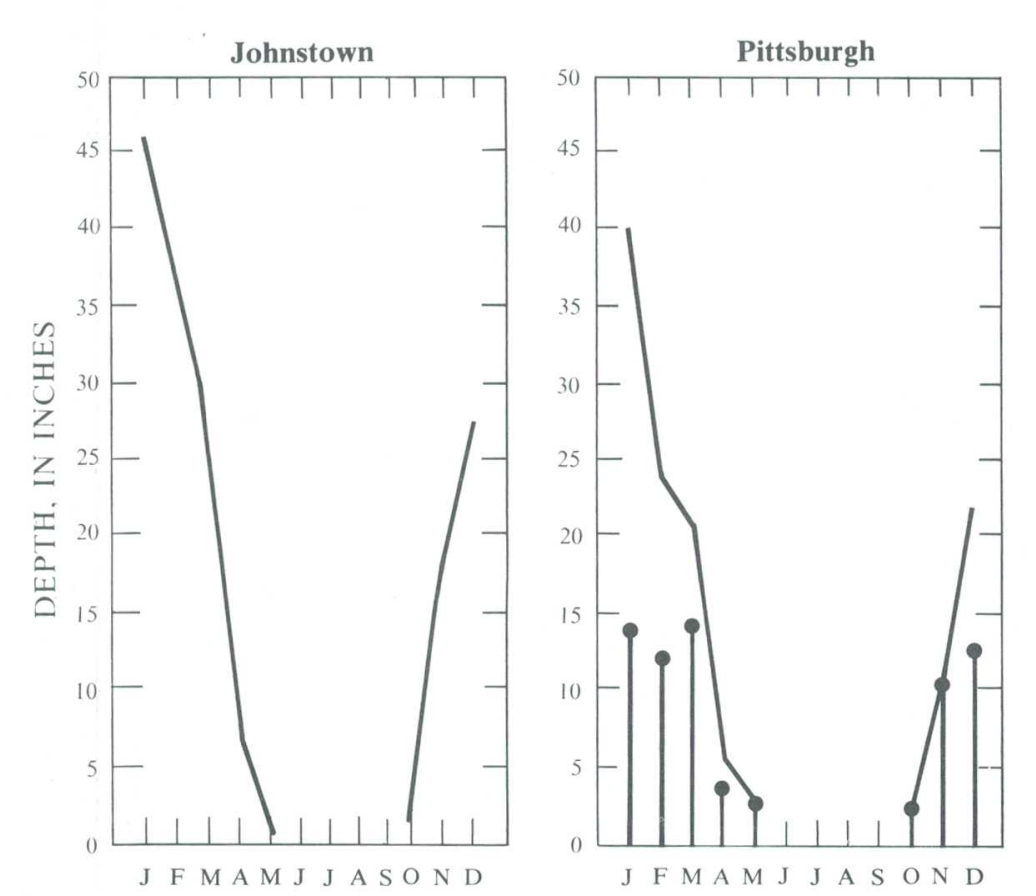

Figure 4.4-3 Variation in snowfall and ice pellets.

Figure 4.4-4 Temperature variation.

Pittsburgh

EXPLANATION

Maximum monthly precipitation

24-hour precipitation

Data from U.S. Deparment of Commerce, 1973

4.0 GENERAL FEATURES OF STUDY AREA (CONTINUED) 4.4 CLIMATE 


\title{
5.0 COAL IN STUDY AREA \\ 5.1 Areal Extent
}

\section{FOUR OF PENNSYLVANIA'S SIX COAL FIELDS PRESENT IN THE AREA}

\author{
Area 3 is underlain by the Monongahela, \\ Allegheny, Pottsville, and Conemaugh coal fields.
}

Figure 5.1-1 shows that most of Eastern Coal Province Area 3 is underlain by coal. Four of the State's six coal fields, the Monongahela, Allegheny, Pottsville, and Conemaugh, are found in the area. The Conemaugh coal field underlies most of the area. The second most extensive coal field is the Allegheny. The Monongahela and Pottsville occupy scattered, but locally extensive portions of the area.

Although the Conemaugh field is found in all parts of Area 3 except near the northern and southern borders, and scattered interior locations, it is generally thin and not mined. However, within this field, the Wellsburg, Barton, and Bakerstown coals are locally workable, as in Butler County (Sisler, 1961).

The Allegheny field is most extensive near the northern border of Area 3, and is common near Johnstown. It is also found in other scattered sections of the Area, notably along the Allegheny and Kiskiminetas Rivers, and Twolick Creek. The Allegheny field contains the Upper and Lower Freeport; Upper, Middle, and Lower Kittanning; Brookville; and Clarion coals. These coals range from 2 to $6 \mathrm{ft}$ thick and are important or locally mineable in most sections of Area 3.

The Monongahela coal field is common in the Loyalhanna Creek basin and is also found in other parts of the Kiskiminetas River basin. It contains the Waynesburg, Sewickley, Redstone, and Pittsburgh Coals. These coals range from locally mineable to important in Allegheny, Somerset, and Westmoreland Counties (Sisler, 1961).

The Pottsville coal field is locally common along Redstone Creek and the Allegheny River in the northern part of Area 3. It is also found west of Johnstown and near the southern border of the Area. The Pottsville contains the Quakerstown, Sharon, and Alton Coal Groups. None of the Pottsville Coals are major producers in the area.

A few scattered areas along the southeastern border of the Area and along the Somerset-Westmoreland County line contain no coal. A few scattered areas underlain by no coal are also found northeast of Ligonier.

The Redbank Creek basin is mainly underlain by Allegheny coals, although areas adjacent to the creek itself are underlain by Pottsville coals. The Crooked, Buffalo, and Blacklick Creek basins are underlain by Conemaugh coals except in the vicinity of the main stream channels where Allegheny coals predominate. The lower part of the Mahoning Creek basin is underlain by Allegheny coals, whereas Conemaugh coals are more common in the upper part. The Stony Creek basin is primarily underlain by Allegheny and Conemaugh coals, but Pottsville coals are common in the headwaters of the Shade Creek. The Loyalhanna Creek basin contains some Monongahela coals, although the Conemaugh coals are most common. 


$\begin{array}{llll}0 & 10 & 20 & 30 \text { KILOMETERS }\end{array}$

(1)

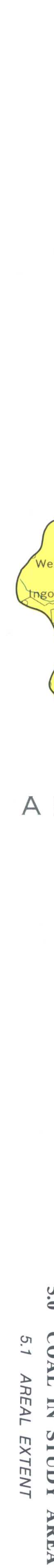

BASE FROM U. S. GEOLOGICAL SURVEY STATE BASE MAP, 1977

CLARION

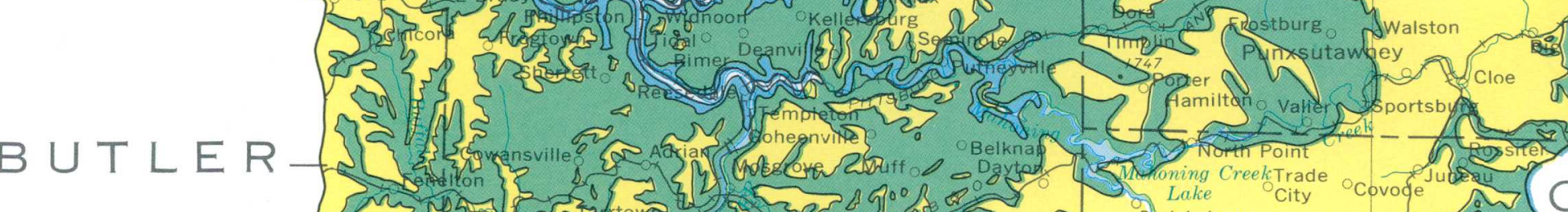

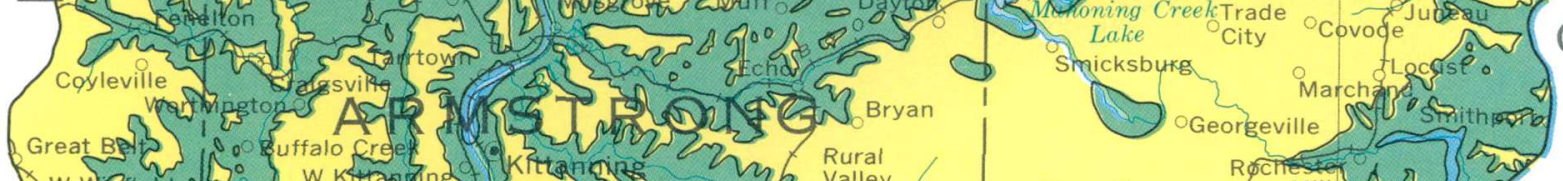

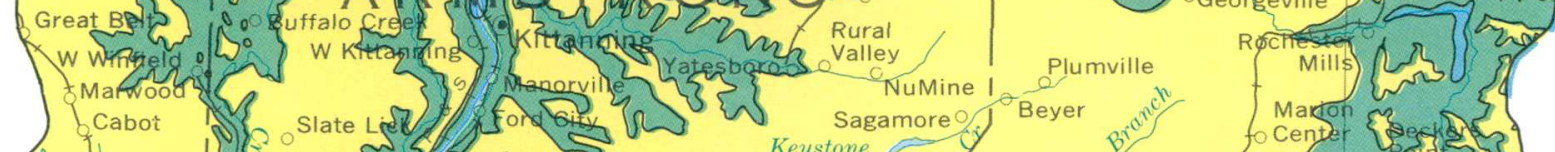

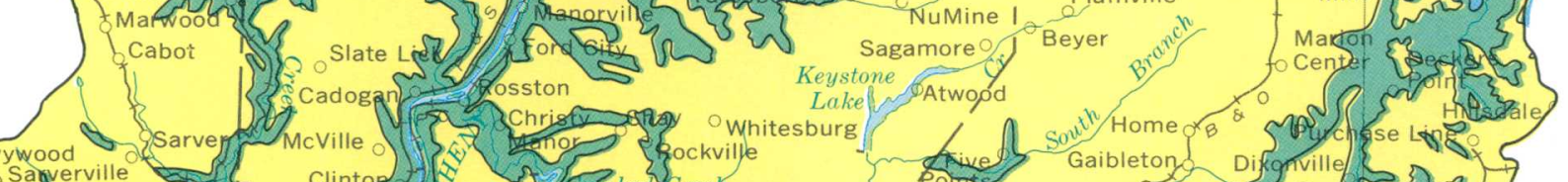

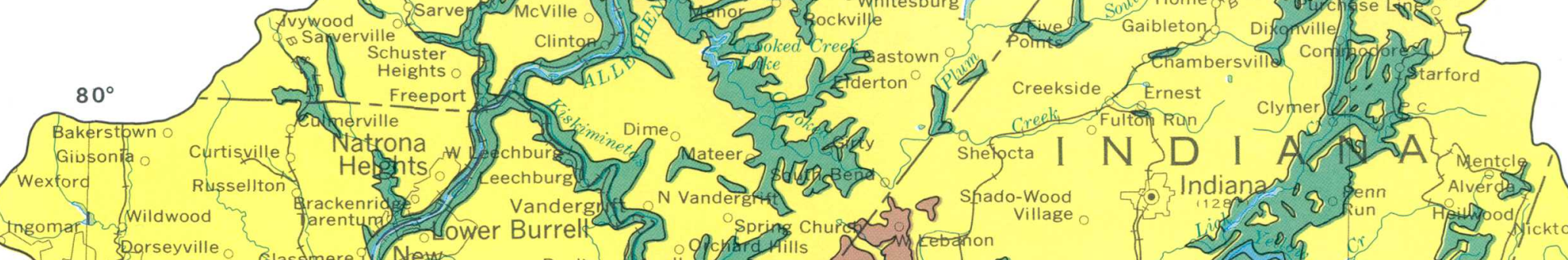

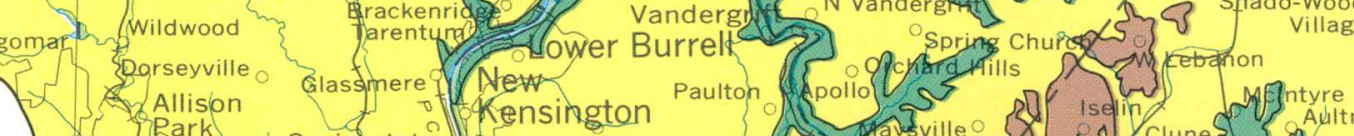

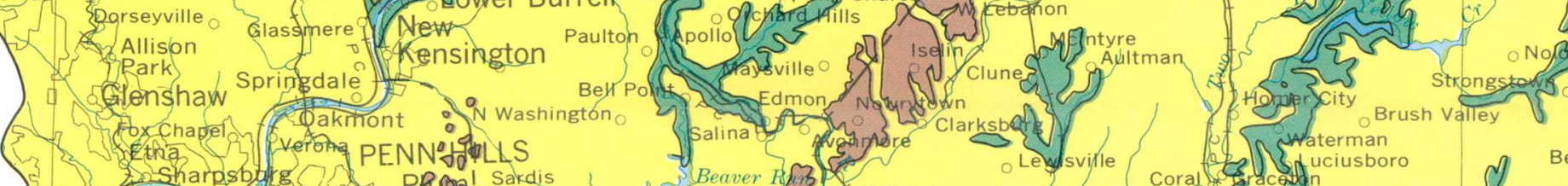

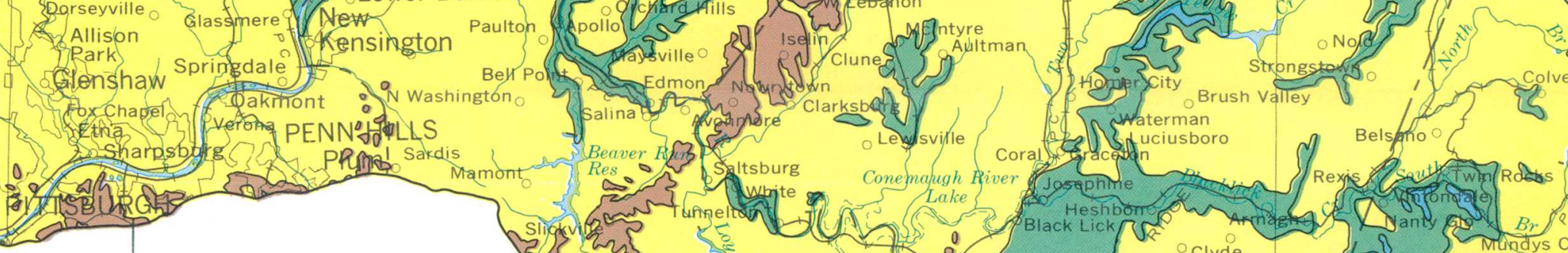
$80^{\circ}$

A L L E G H E Y

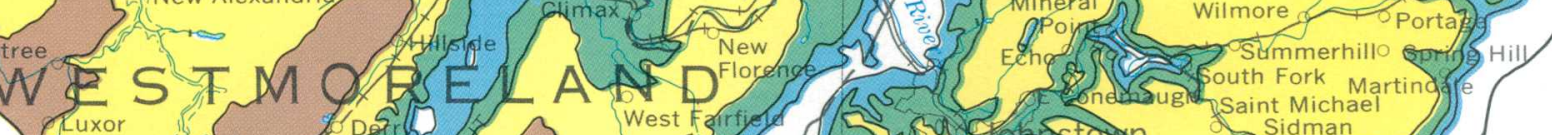

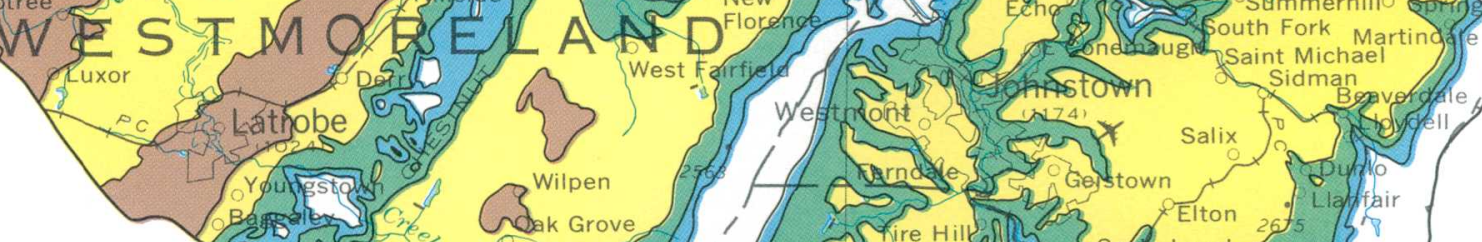

Wilpen

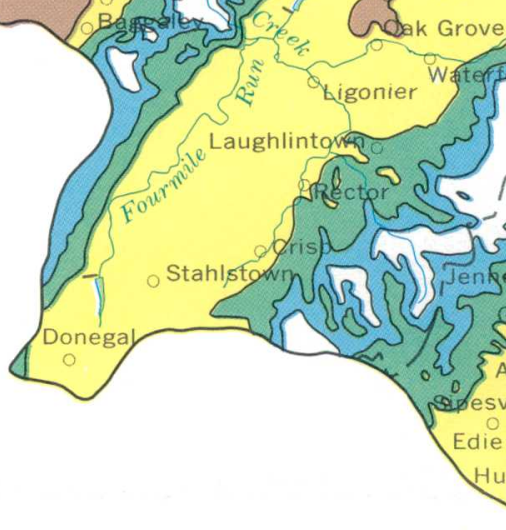

SOMERSET

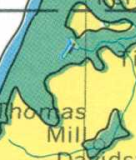




\title{
5.0 COAL IN STUDY AREA (Continued) \\ 5.2 Trends in Coal Production
}

\section{COUNTIES IN AREA PRODUCE ALMOST 50 MILLION TONS OF BITUMINOUS COAL PER YEAR}

\author{
During 1974-78, annual bituminous coal production in the \\ nine counties of Area 3 ranged from 46,200,000 \\ to 53,000,000 tons, and averaged 49,900,000 tons.
}

\begin{abstract}
Eastern Coal Province Area 3 contains all or part of nine coal-producing counties. Counties in the study area are Allegheny, Armstrong, Butler, Cambria, Clearfield, Indiana, Jefferson, Somerset, and Westmoreland.

Figure 5.2-1 depicts coal production by county and total coal production in the nine-county area. During the 5 years, 1974-78, total annual coal production in Area 3 counties ranged from a low of $46,200,000$ tons in 1974 to a high of $53,000,000$ tons in 1977 (Commonwealth of Pennsylvania, 1978). The average for the 5 years is $49,900,000$ tons or 68 percent of Pennsylvania's production. There was a
\end{abstract}

steady increase in production during 1974-77 and a decrease in 1978. Because some counties are only partly within Area 3, these figures somewhat overstate production from the area.

Indiana County is the leading coal producer in Area 3. Annual production during 1974-78 ranged from a low of $9,027,000$ tons in 1978 to $10,802,000$ in 1976. Clearfield County produced an annual average of $8,600,000$ tons. Cambria and Armstrong are also major producers in Area 3. These counties averaged $7,330,000$ and $7,120,000$ tons per year, respectively, for 1974-78. 

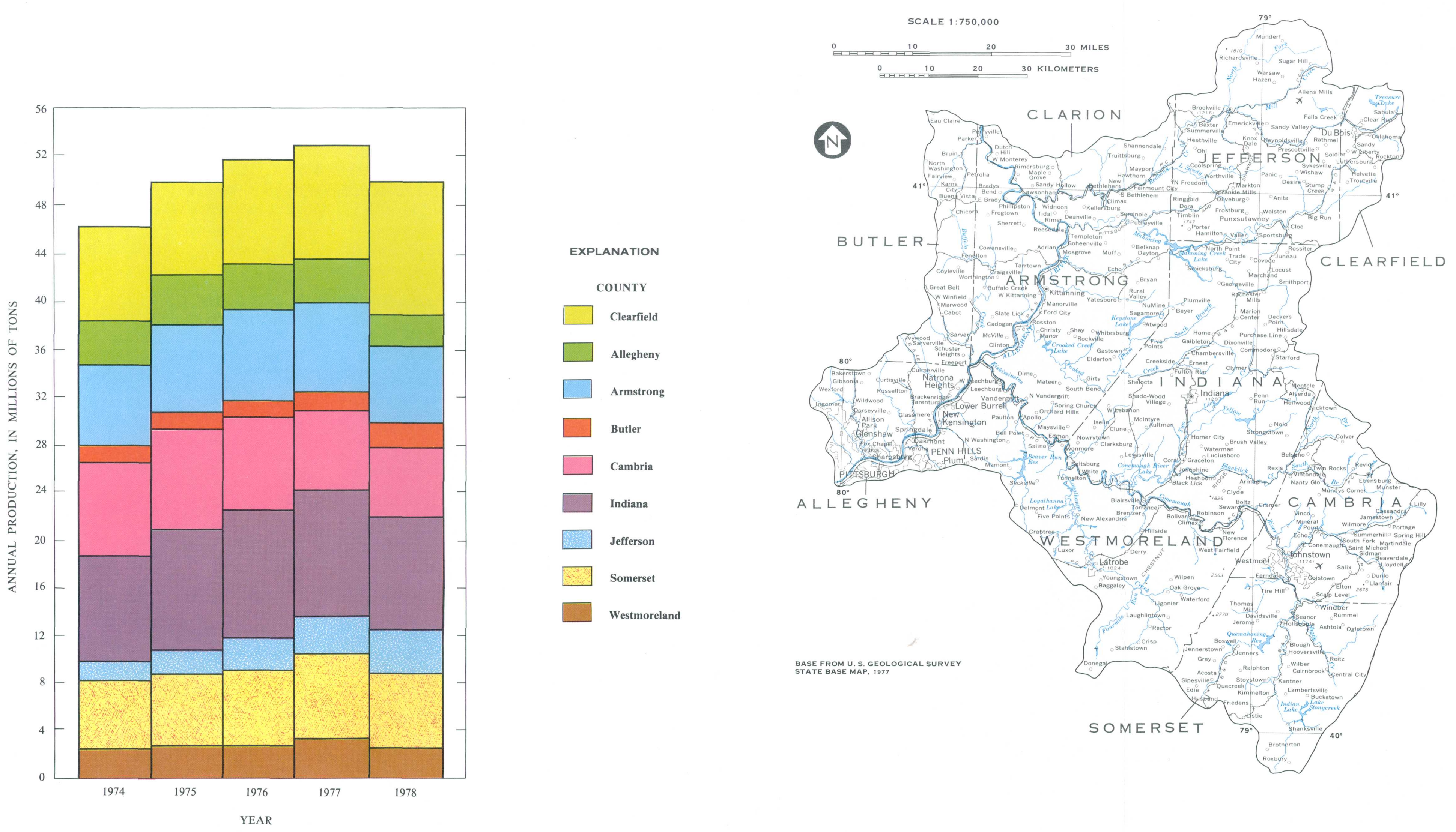

Figure 5.2-1 Coal production, total and by county 


\title{
6.0 COAL HYDROLOGY NETWORK \\ 6.1 Surface-Water Quantity
}

\section{STREAMFLOW DATA COLLECTED AT 122 LOCATIONS IN AREA}

\author{
Systematic streamflow data have recently been collected \\ at 23 continuous-record gaging stations, 3 crest-stage \\ partial-record stations, 6 low-flow partial-record \\ stations, and additional measurements of discharge have \\ been obtained at 70 miscellaneous sites.
}

\begin{abstract}
Systematic collection of streamflow data at an established network of stations is a key ingredient in the assessment of the hydrology of any area. If streamflow data are collected over a period of time, it is possible to make estimates of certain streamflow characteristics at the stations. Such systematic data collection also provides the ability to make estimates of streamflow characteristics for sites where data are not collected. Systematic surface-water data are generally collected at continuous-record or partial-record stations. Additional surface-water data may be collected at miscellaneous sites.
\end{abstract}

Continuous-record stations are locations where a continuous record of stream stage (height of the water surface above an arbitrary datum) is collected. The stage information is generally collected and recorded by a variety of automatic recorders. Periodic measurements of actual stream-flow or discharges relate specific stages to specific discharges. The continuous record of stage, combined with the stage-discharge relation, provides a continuous record of streamflow. Such continuous streamflow data are usually converted to yield a mean daily discharge, although instantaneous discharges at specific times during the day can also be determined. Continuous-record stations provide the most detailed streamflow data. Figure 6.1-1 shows the locations of 23 continuous-record stations in Area 3, and Appendix 1 provides station names and drainage areas.

Partial-record stations supplement the networks of continuous-record stations. They provide additional data at a much lower cost than that provided by a continuous-record station although much detail is lost. Low-flow partial-record stations have no recording devices, but rather are measured directly during low flow. Relationships between concurrent flows at the partial-record and continuous-record stations extend the areal coverage of low-flow data. Crest-stage partial-record stations, on the other hand, utilize a simple gage to record the maximum stage reached by a stream during a runoff event. A stage-discharge relation, developed through a series of direct discharge measurements and indirect discharge determinations, is then used to compute the peak flow during the event. Such peak-flow data can be analyzed to determine the flood-frequency characteristics of a stream. Figure 6.1-1 shows the locations of 3 crest-stage and 6 low-flow partial-record stations in the area, and Appendix 1 provides station names and drainage areas.

Miscellaneous sites further supplement the network of continuous-record stations. Streamflow is measured at these stations when visited, but no particular effort is made to obtain measurements of high or low flows. Such measurements can be used in conjunction with water-quality data to compute loads of various dissolved or suspended constituents. Figure 6.1-1 shows the locations of 70 miscellaneous sites in the area, and Appendix 1 provides station names and drainage areas. 


\begin{tabular}{llll}
0 & 10 & 20 & 30 \\
\hline
\end{tabular}

\section{(1)}

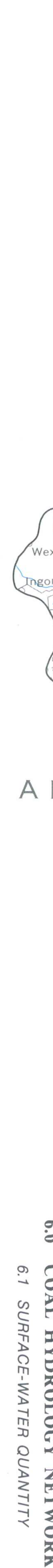

BASE FROM U. S. GEOLOGICAL SURVEY BASE FROM U. S. GEOLOG

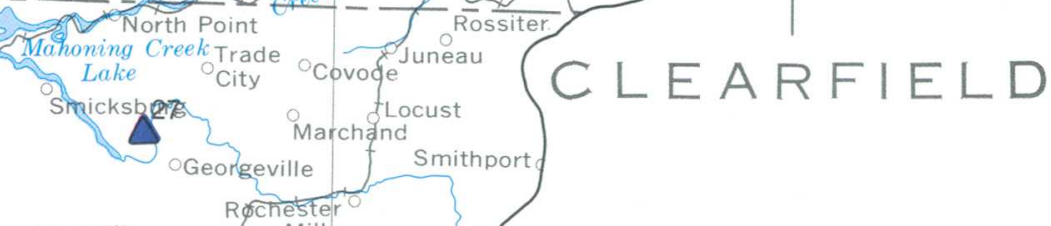

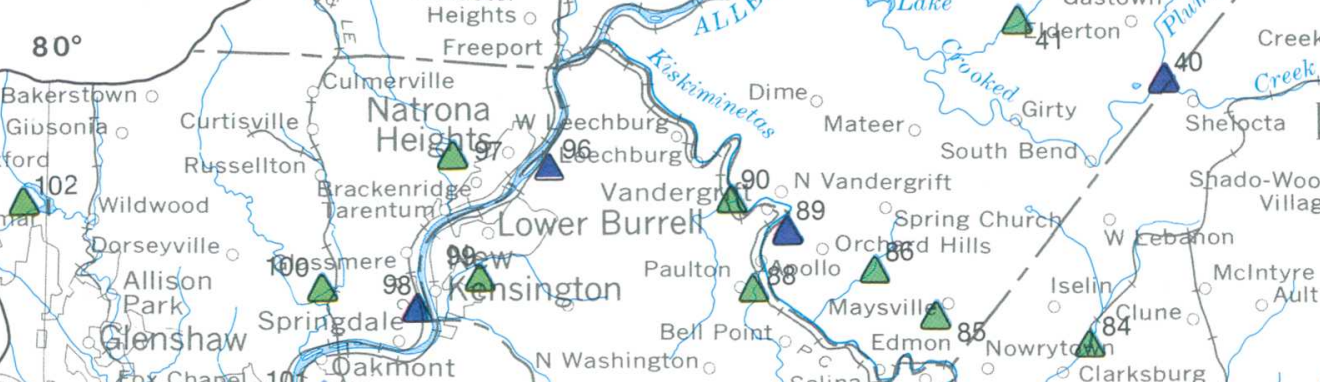

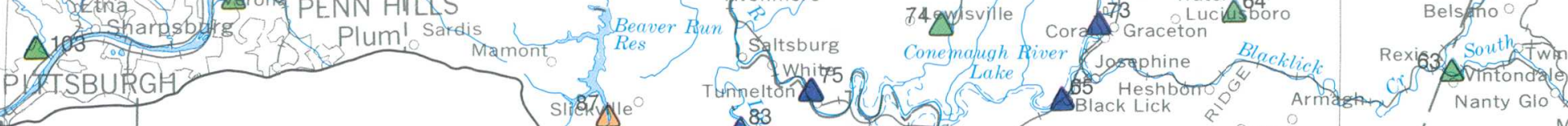

LEGHENY

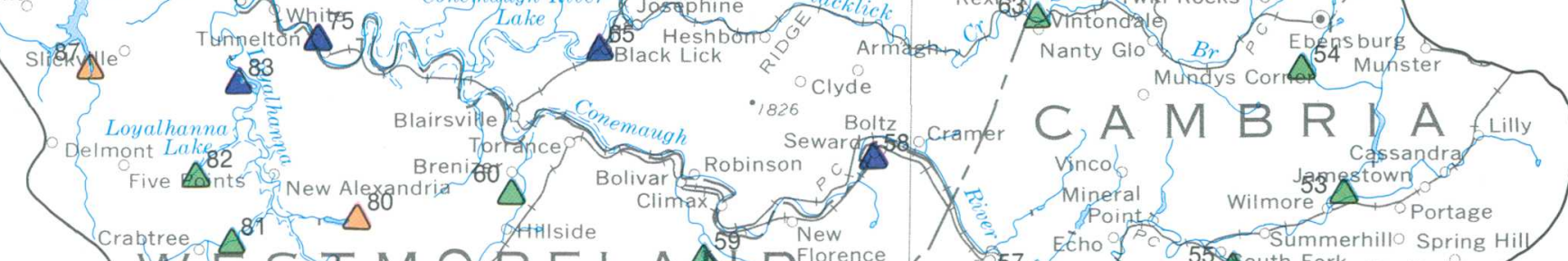

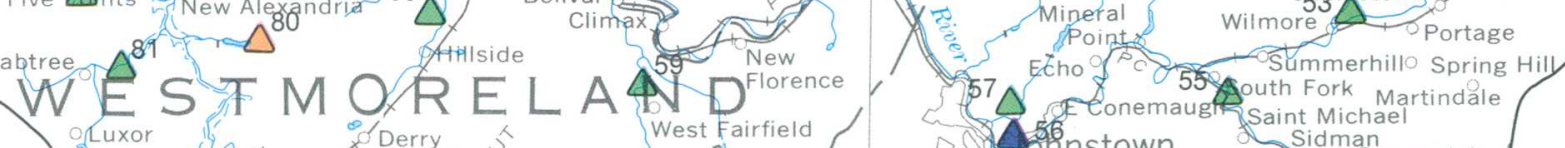
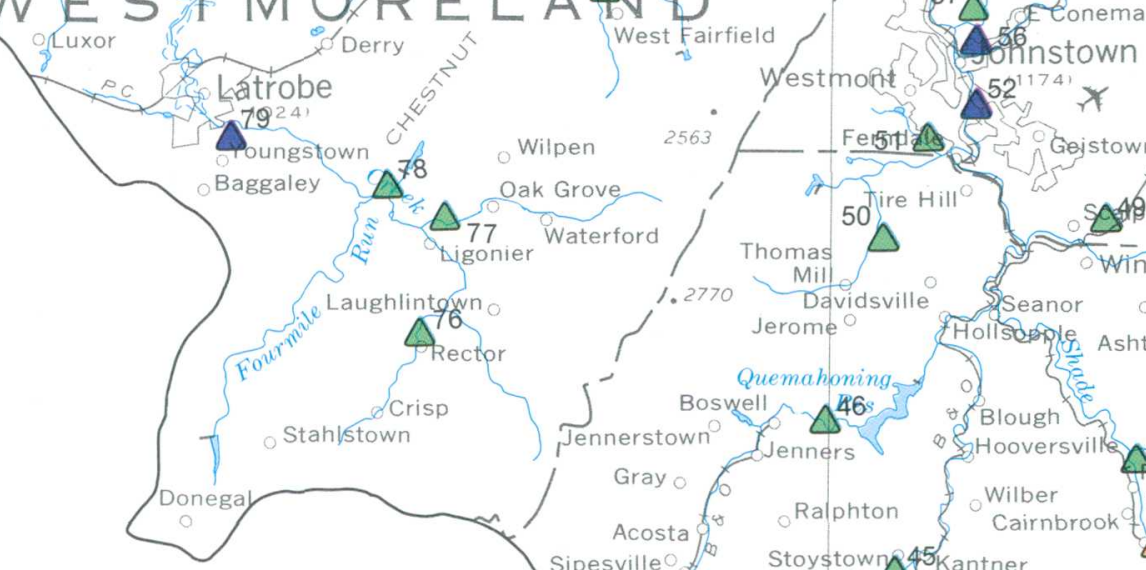

Westmonit of $\Delta^{52^{1741}}$
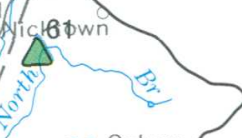


\title{
6.0 COAL HYDROLOGY NETWORK (Continued) \\ 6.2 Surface-Water Quality
}

\section{RECENT WATER-QUALITY DATA COLLECTED AT 87 LOCATIONS IN AREA}

\author{
Water-quality and daily streamflow data \\ are available for 14 stations in Area 3. \\ Miscellaneous water-quality data are \\ available for 73 sites in the area.
}

Figure 6.2-1 shows the locations of 14 gaging stations having daily streamflow data and water-quality data. Water-quality data were collected at these sites (with the exception of sites 40,52 , and 79) for several years during the latter half of the 1970's. Six of these 14 sites, $20,40,52,73,79$, and 99 were selected for continued water-quality sampling as part of a continuing effort to describe the hydrology of coal areas. Site 20 is designated as a trend site; data from this site will be used to detect long-term changes in water quality. Station names and drainage areas for the continuous-record stations are provided in Appendix 1.

In order to increase the water-quality data base for Eastern Coal Province Area 3, 73 miscellaneous monitoring locations were established. Figure 6.2-1 shows the location of these monitoring stations, known as synoptic sites, and Appendix 1 provides station names and drainage areas. The map also shows the drainage basin that is monitored at each synoptic site. Any activity affecting water quality or quantity taking place upstream from a synoptic site may be reflected at the site. However, if the change is small or transitory, it may not be detected at the synoptic site.

All first order streams in coal-bearing sections of Area 3 were initially considered for a synoptic site. First order streams were defined as those unbranched streams appearing on a 1:500,000 scale Hydrologic Unit map. A subset of these first order streams was selected for actual synoptic site location. The final site selection was designed to provide broad areal coverage in Area 3.

Synoptic sites were located on 73 streams having drainage areas ranging from 2.46 to $87.4 \mathrm{mi}^{2}$. The mean drainage area for all streams was about $18 \mathrm{mi}^{2}$. About one-third of the streams have drainage areas between 16 and $32 \mathrm{mi}^{2}$ while about one-fourth of the streams have drainage areas larger than $32 \mathrm{mi}^{2}$. 


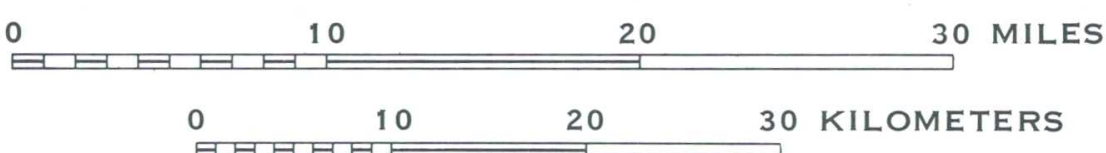

30 MILES
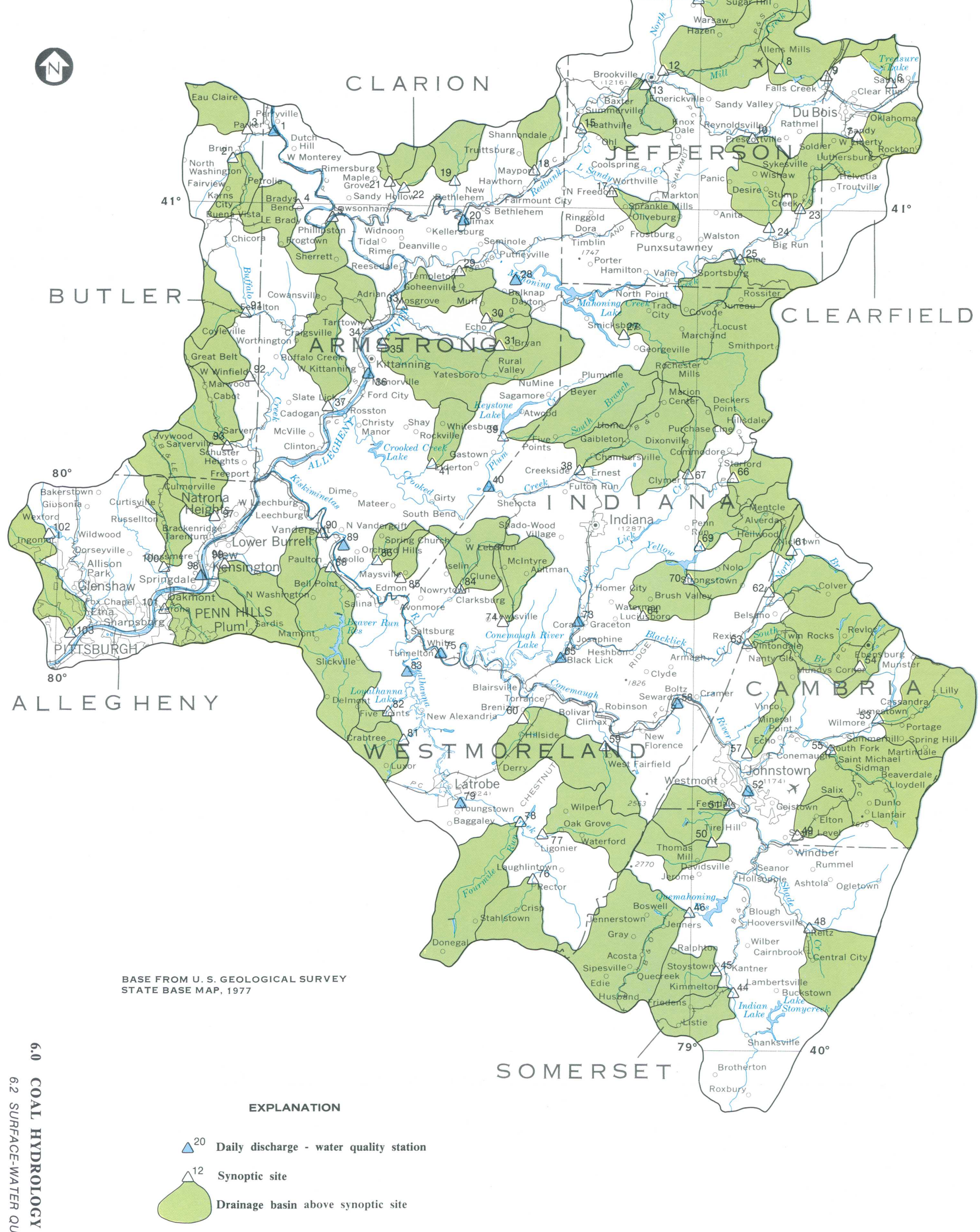

30 KILOMETERS

Figure 6.2-1 Locations of water-quality sites and synoptic site drainage basins 


\title{
6.0 COAL HYDROLOGY NETWORK (Continued) \\ 6.3 Type and Scheduling of Samples
}

\section{SAMPLING NETWORK IS DESIGNED TO DEFINE COAL-RELATED WATER QUALITY IN AREA}

\author{
A network of 73 synoptic sites and 6 continuous-record \\ stations is being sampled to collect water-quality data \\ which may be related to the presence of coal or coal \\ mining. The sampling schedule is designed to collect \\ data over a range of flow conditions.
}

The present sampling program of the coal hydrology network utilizes two types of sampling stations, each having a distinct purpose. A large network of synoptic sites is designed to provide broad areal coverage, while a smaller network of continuous-record stations is designed to provide more detailed information on changes in water quality over time.

Water-quality samples and measurements of discharge (streamflow) are planned for at least three different flow conditions at synoptic sites. Samples have been collected under high and intermediate base flow conditions at most synoptic sites. Climatic conditions prevented adequate low base-flow sampling prior to preparation of this report. Future plans include sampling at low base flow.
Table 6.3-1 lists the types and frequencies of data collection at the 73 synoptic sites. These data were selected to concentrate on information which may be useful in coal-bearing areas. Many of the waterquality constituents listed in table 6.3-1 are specifically mentioned in the surface mining regulations. These water-quality data are published by U.S. Geological Survey $(1980,1981)$.

Similar data are being collected at the six continuous-record stations in Area 3's coal hydrology network. Samples are being collected more frequently than at the synoptic sites and additional samples are being collected. Table 6.3-2 lists the types and frequencies of sampling at the continuous-record stations. The data collected at these sites have been published by U.S. Geological Survey $(1980,1981)$. 
Each visit (6-9, times annually)

\begin{tabular}{ll} 
Discharge & $\begin{array}{l}\text { Dissolved iron } \\
\text { Temperature }\end{array}$ \\
Tpecific conductance & Dissolved manganese \\
pH & Sulfate \\
Alkalinity & Residue, dissolved \\
Acidity & Suspended sediment \\
Total iron & \\
& Annually (low flow) \\
\hline
\end{tabular}

\section{Each visit (low, medium, and high flows)}

Discharge

Temperature

Dissolved iron

Dissolved manganese

Sulfate

Alkalinity

Acidity

Total iron

Annually (low flow)

Identification of benthic invertebrates

\section{One time only (low flow)}

Bottom materials

\begin{tabular}{ll} 
Arsenic & Manganese \\
Cadmium & Mercury \\
Chromium & Selenium \\
Cobalt & Zinc \\
Copper & Organic carbon \\
Iron & Inorganic carbon \\
Lead & Coal \\
& \\
\multicolumn{1}{c}{ Storm events (high flow) } \\
\cline { 2 - 2 }
\end{tabular}

Suspended sediment and discharge
Identification of benthic invertebrates

One time only (low flow)

Bottom material

$\begin{array}{ll}\text { Arsenic } & \text { Manganese } \\ \text { Cadmium } & \text { Mercury } \\ \text { Chromium } & \text { Selenium } \\ \text { Cobalt } & \text { Zinc } \\ \text { Copper } & \text { Organic carbon } \\ \text { Iron } & \text { Inorganic carbon } \\ \text { Lead } & \text { Coal } \\ & \text { Common constituents } 1\end{array}$

$\begin{array}{ll}\text { Sodium absorption ratio } & \text { Dissolved fluoride } \\ \text { Sodium percent } & \text { Residue, dissolved } \\ \text { Dissolved calcium } & \text { Dissolved silica } \\ \text { Dissolved manganese } & \text { Dissolved sulfate } \\ \text { Dissolved potassium } & \text { Nitrite plus nitrate } \\ \text { Dissolved sodium } & \text { Total phosphorus } \\ \text { Dissolved chloride } & \text { Total alkalinity }\end{array}$

Minor elements

$\begin{array}{ll}\text { Total barium } & \text { Total manganese } \\ \text { Total cadmium } & \text { Total silver } \\ \text { Total chromium } & \text { Total zinc } \\ \text { Total copper } & \text { Total arsenic } \\ \text { Total iron } & \text { Total selenium } \\ \text { Total lead } & \text { Cyanide } \\ & \text { Total mercury }\end{array}$

At continuous-record sites designated trend or reference collection is annually at low flow. Storm sediment data are also collected at trend and reference sites. 


\title{
7.0 SURFACE-WATER QUALITY \\ 7.1 Specific Conductance
}

\section{HIGHEST SPECIFIC CONDUCTANCES MOST COMMON IN FOUR DRAINAGE BASINS IN AREA}

\author{
Specific conductances in excess of 1,000 $\mu \mathrm{mho} / \mathrm{cm}$ \\ (micromhos per centimeter) were found in the Redbank \\ Creek, Blacklick Creek, and lower Kiskiminetas River \\ basins and in tributaries to the Kiskiminetas River. \\ Maximum specific conductances measured in Area 3 \\ ranged from 60 to $6,600 \mu \mathrm{mho} / \mathrm{cm}$.
}

Figure 7.1-1 illustrates that the highest specific conductances in Eastern Coal Province Area 3 were generally confined to four drainage basins. The Redbank Creek basin, located northeast of Butler, contains streams having high specific conductances. A second basin having high specific conductances is the Blacklick Creek basin, north of Johnstown. High specific conductances are also found in the lower Kiskiminetas River basin and in tributaries to the Allegheny River downstream from the mouth of the Kiskiminetas River. The maximum specific conductance measured at each of 72 stream sites ranged from a low of $60 \mu \mathrm{mho} / \mathrm{cm}$ to a high of $6,600 \mu \mathrm{mho} /$ $\mathrm{cm}$. The average maximum specific conductance measured at each site was $790 \mu \mathrm{mho} / \mathrm{cm}$. Figure 7.1-2 shows that 41 of 72 streams had a maximum specific conductance of $500 \mu \mathrm{mho} / \mathrm{cm}$ or less, and only 14 streams had maximum specific conductances greater than $1,000 \mu \mathrm{mho} / \mathrm{cm}$. Specific conductances of less than $500 \mu \mathrm{mho} / \mathrm{cm}$ were generally found at streams whose minimum $\mathrm{pH}$ was greater than 6.5 .

Figure 7.1-3 illustrates the range and mean of measured specific conductances at four continuousrecord stations in Area 3 during the 1976 and 1977 water years. Figure 7.1-3 shows specific conductance may vary considerably with time even in a single stream. Each of the four streams exhibited a negative correlation between instantaneous discharge and specific conductance. The correlations were all significant at the 95-percent confidence level. In spite of the variations within the individual streams, a two-sample t-test indicated that the means for all four stations are significantly different, except when comparing 73 and 83 .

Water samples were tested for specific conductance at 72 stream sites in Area 3 during June 1979 to April 1980 according to procedures outlined by Skougstad and others (1979). Most sites were tested three times, once during high base flow and twice during intermediate base flow. Sampling at low base flow is included in future plans. Data for the 1979 and 1980 water years are published by U.S. Geological Survey $(1980,1981)$. 


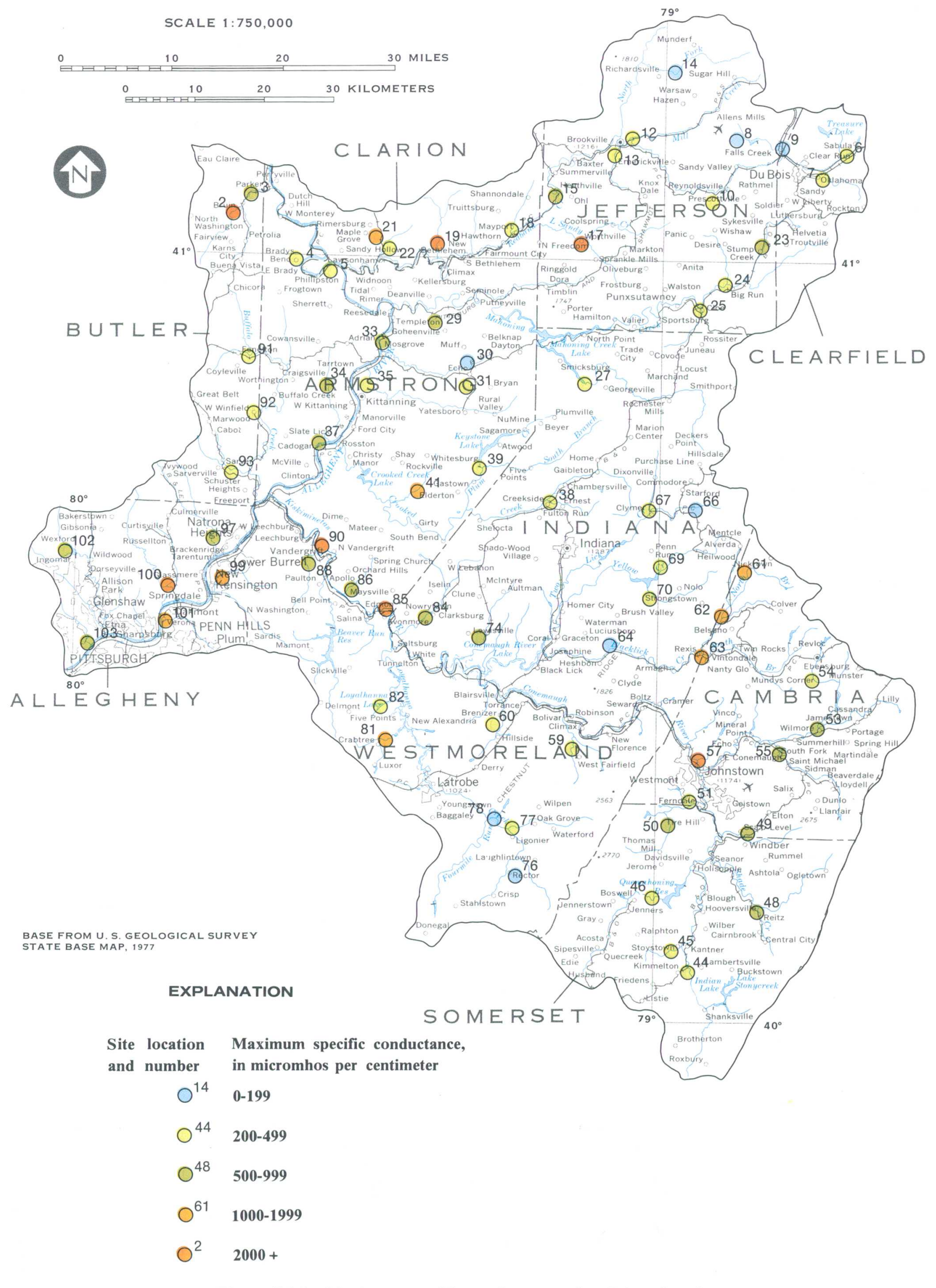

Figure 7.1-1 Maximum specific conductances found in selected streams.

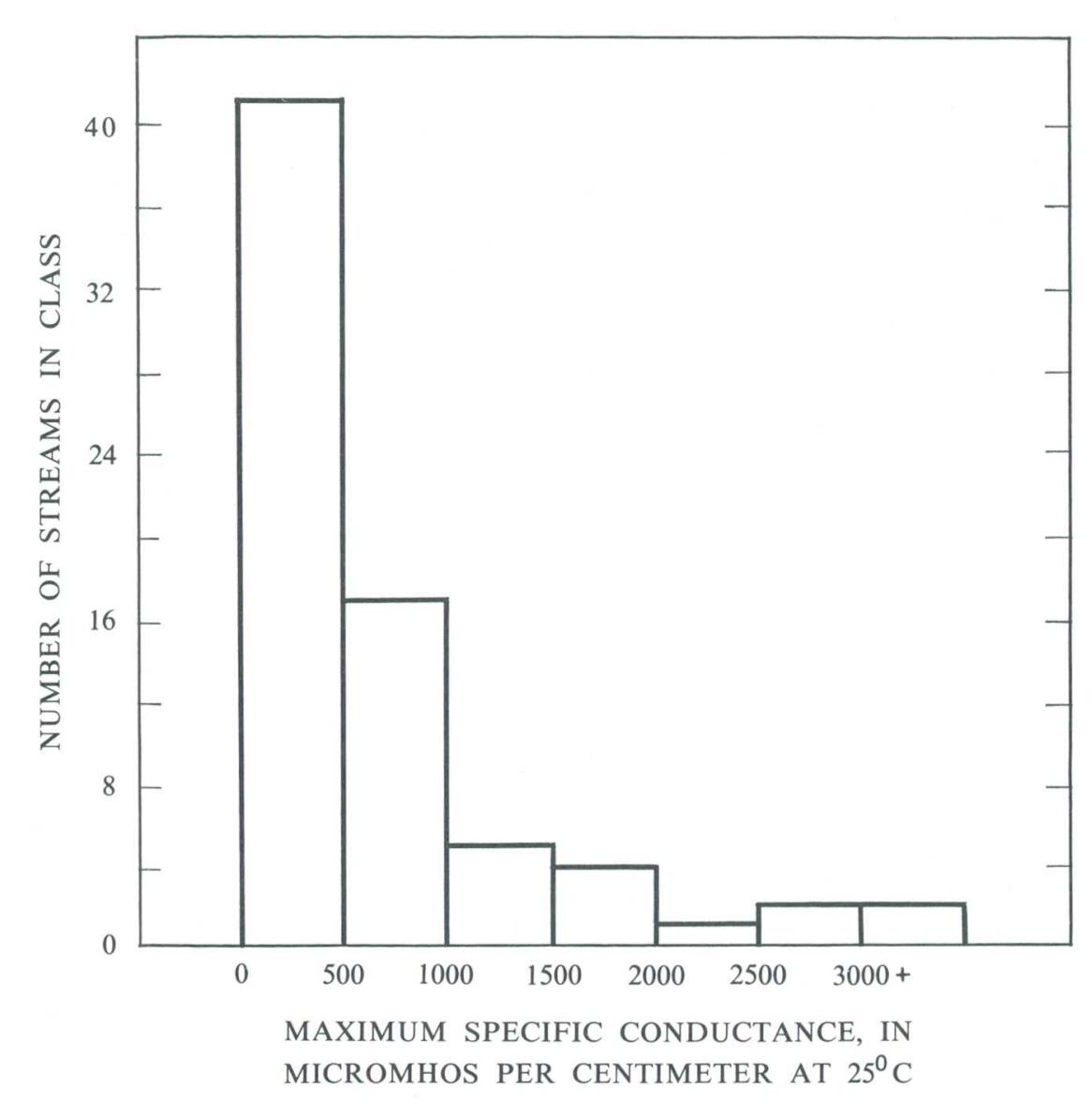

Figure 7.1-2 Histogram of maximum specific conductances for selected streams.

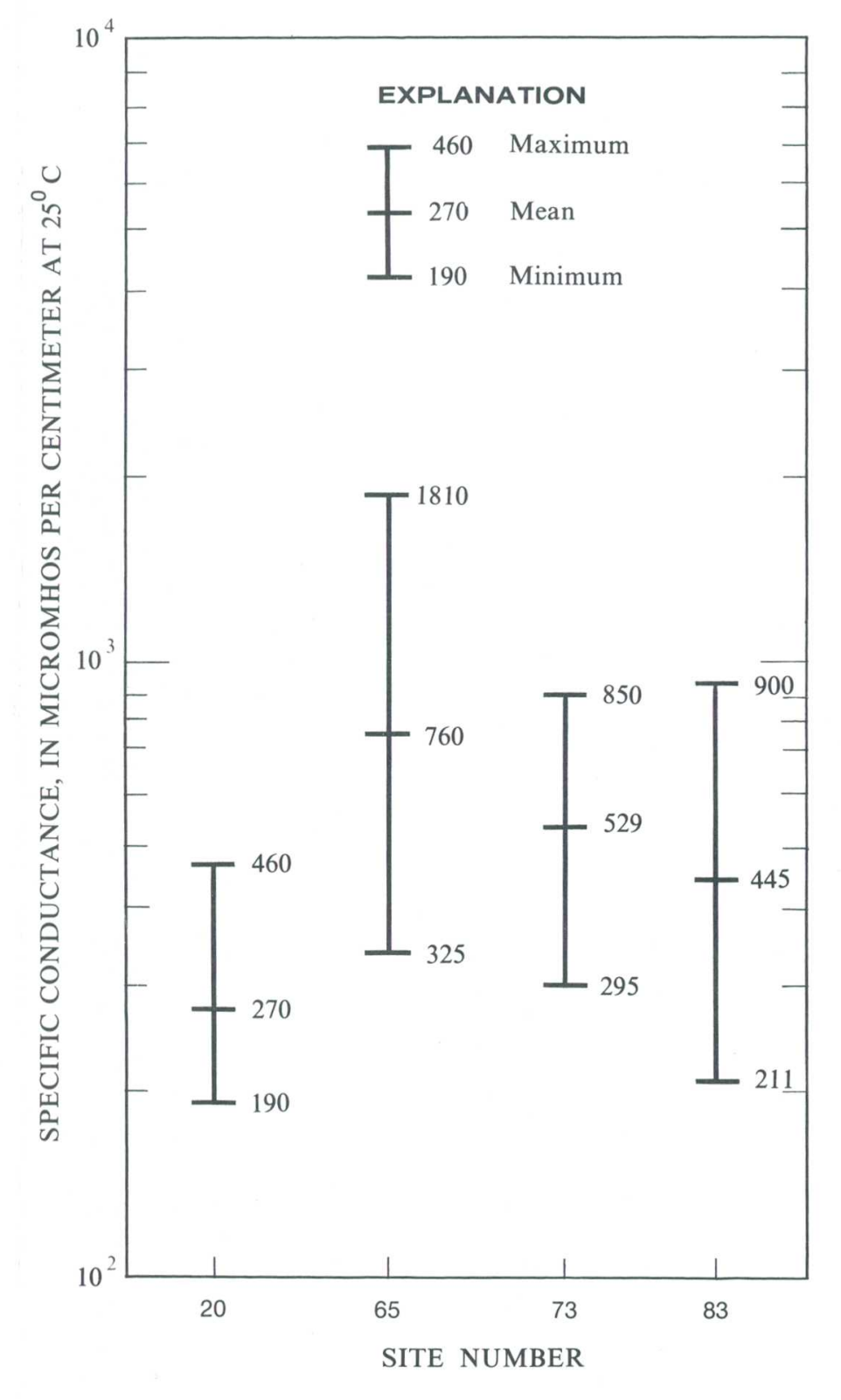

Figure 7.1-3 Ranges and means of specific conductance at selected continuous-record stations, 1976 and 1977 water years. 


\title{
7.0 SURFACE-WATER QUALITY (Continued) \\ 7.2 Dissolved Solids
}

\section{HIGHEST DISSOLVED-SOLIDS CONCENTRATIONS WERE FOUND IN FIVE DRAINAGE BASINS IN AREA}

\author{
The highest dissolved-solids concentrations in Area 3 were \\ found in the Redbank Creek, Blacklick Creek, Conemaugh River, \\ and lower Kiskiminetas River basins, and in tributaries to the \\ Allegheny River downstream from the Kiskiminetas River. The \\ maximum dissolved-solids concentrations at sites in the \\ area ranged from 44 to $4,390 \mathrm{mg} / \mathrm{L}$ (milligrams per liter).
}

Figure 7.2-1 illustrates that the highest dissolved-solids concentrations in streams in Eastern Coal Province Area 3 were generally found in five drainage basins. One drainage basin having high dissolved-solids concentrations is the Redbank Creek basin, northeast of Butler. A second basin having high dissolved solids is the lower Kiskiminetas River basin in the vicinity of Vandergrift. The third and fourth drainage basins are the Blacklick Creek and upper Conemaugh River basins, both north of Johnstown. Additionally, high dissolved-solids concentrations are found in tributaries to the Allegheny River downstream from the mouth of the Kiskiminetas River.

The maximum dissolved-solids concentrations found at 72 stream sites ranged from a low of 44 $\mathrm{mg} / \mathrm{L}$ to a high of $4,390 \mathrm{mg} / \mathrm{L}$. The mean maximum dissolved-solids concentration was $430 \mathrm{mg} / \mathrm{L}$ and the median maximum concentration was $220 \mathrm{mg} / \mathrm{L}$. The difference between the mean and the median reflects the effect of a few high dissolved-solids concentrations on the mean. Figure 7.2-2 illustrates that 32 streams had a maximum dissolved-solids concentration of less than $200 \mathrm{mg} / \mathrm{L}$ while only 9 had a maximum concentration greater than $800 \mathrm{mg} / \mathrm{L}$.

A regression relationship using dissolved solids as the dependent variable and specific conductance as the independent variable shows a close relationship between these measures of water quality. The equation:

$$
\mathrm{ROE}=10.9+0.68(\mathrm{SC})
$$

expresses the relation between residue on evaporation at $180^{\circ} \mathrm{C}$ (dissolved solids) and specific conductance where:

ROE $=$ residue on evaporation at $180^{\circ} \mathrm{C}$ in milligrams per liter, and

$\mathrm{SC}=$ specific conductance in micromhos per centimeter at $25^{\circ} \mathrm{C}$.

This relation explains over 90 percent of the variation of dissolved solids. The standard error of the estimate for the equation is plus or minus 148 $\mathrm{mg} / \mathrm{L}$. The relation is shown graphically in figure 7.2-3. The equation was developed using 122 data pairs. The slope $(0.68)$ falls well within the range of 0.55 to 0.75 reported by Hem (1970) for most waters.

Water samples for dissolved-solids determinations (Skougstad and others, 1979) were collected at 72 stream sites during June 1979 to April 1980. Generally one sample was collected during high base flow and two samples were collected during intermediate base flow. Future plans include low flow samples. Dissolved-solids data for the 1979 and 1980 water years are published by the U.S. Geological Survey $(1980,1981)$. 



\title{
7.0 SURFACE-WATER QUALITY (Continued) \\ $7.3 \mathrm{pH}$
}

\section{LOWEST pH VALUES MOST COMMON IN THREE DRAINAGE BASINS IN AREA}

\author{
The lowest $\mathrm{pH}$ values (less than 4.5) \\ in Area 3 were found in the Redbank \\ Creek, Blacklick Creek, and upper \\ Conemaugh River basins. Minimum pH \\ values measured at each site in the \\ area ranged from 3.2 to 7.9 .
}

Figure 7.3-1 illustrates that streams having the lowest $\mathrm{pH}$ values generally were confined to three basins in Eastern Coal Province Area 3. Streams in Redbank Creek basin having low $\mathrm{pH}$ are located northeast of Butler. Low $\mathrm{pH}$ values were also relatively common in the Blacklick Creek and upper Conemaugh River basins near Johnstown. The lowest value of $\mathrm{pH}$ measured at each of 72 stream sites ranged from a low of 3.2 to a high of 7.9. The average minimum $\mathrm{pH}$ value was 6.2 while the median minimum $\mathrm{pH}$ was 6.7 . Figure $7.3-2$ shows that 14 streams had a minimum pH value in the neutral or alkaline range $(\mathrm{pH}>7.0)$, but 53 streams had a minimum $\mathrm{pH}$ value greater than 6.0. Only 8 of the streams had a $\mathrm{pH}$ value of 4.0 or less.

None of the major rock units in Area 3 are primarily limestone, but outcrops of limestone may occur in many stream valleys. The presence of limestone beds may possibly explain some of the higher $\mathrm{pH}$ values, but the complexity of their outcrop location precluded any detailed analyses.

The $\mathrm{pH}$ was measured at 72 stream sites in Area 3 during June 1979 to April 1980 using procedures ou- tlined by Skougstad and others (1979). Most sites were measured three times, once during high base flow and twice during intermediate base flow. Sampling at low base flow is included in future plans. The data for the 1979 and 1980 water years are published by the U.S. Geological Survey $(1980,1981)$.

Figure 7.3-3 illustrates the variability in $\mathrm{pH}$ observed at four continuous-record stations during the 1976 and 1977 water years. The four stations shown in the figure have mean $\mathrm{pH}$ values of $4.1,4.2,6.4$, and 6.6. Figure 7.3-3 also illustrates that $\mathrm{pH}$ measurements at different times in the same stream can vary widely (3.7 $\mathrm{pH}$ units for site 65$)$. The mean $\mathrm{pH}$ values for most of the streams were significantly different from one another except when comparing site 20 with site 83 and site 65 with site 73 . Figure 7.3-3 demonstrates that some $\mathrm{pH}$ values in each of these streams fell below the OSM (Office of Surface Mining, 1979) effluent limit of $\mathrm{pH} 6.0$. The mean $\mathrm{pH}$ for two of the four streams was below the effluent standard and even the maximum value of 4.5 reported for site 73 violates the standard. 

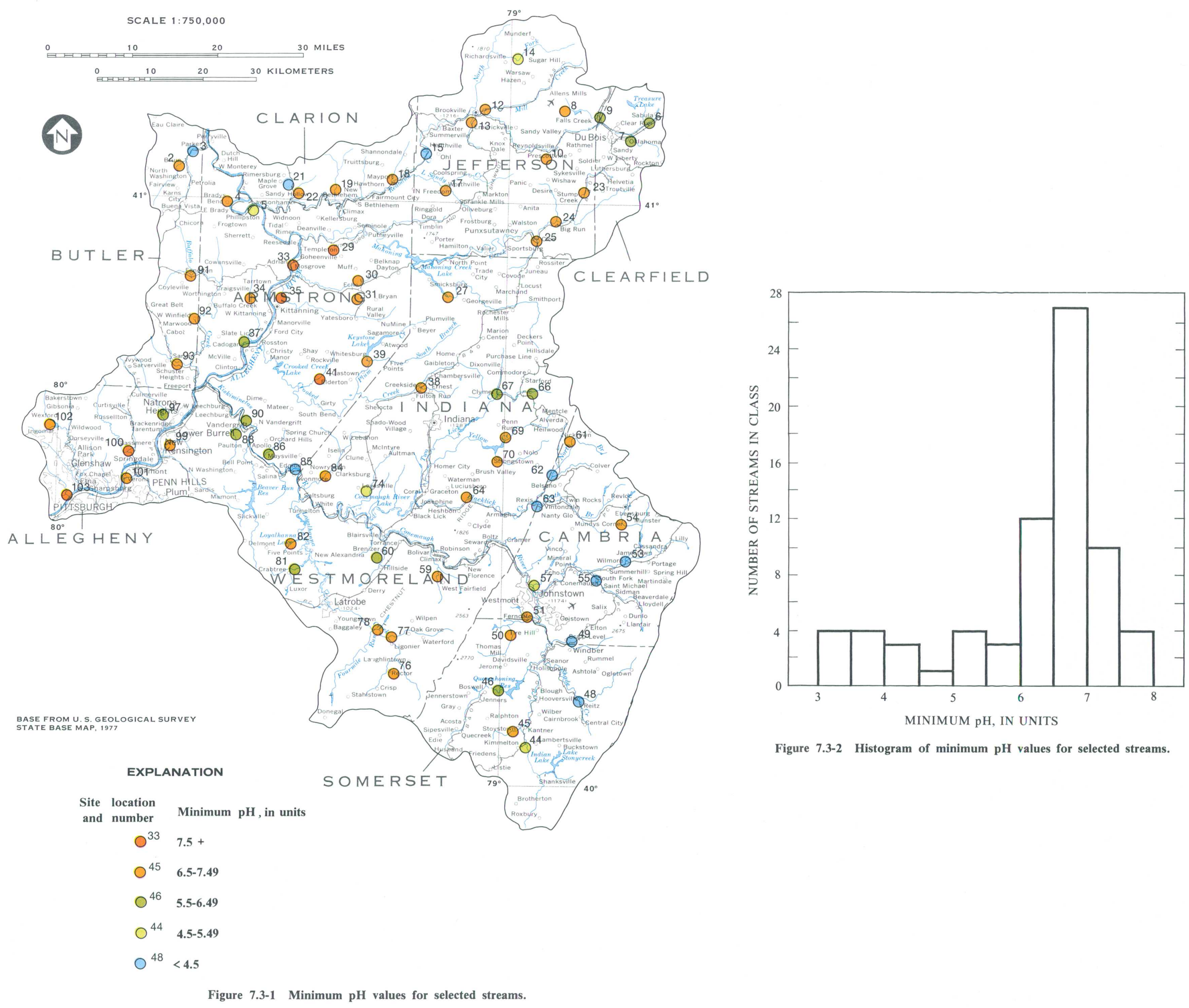

Figure 7.3-2 Histogram of minimum $\mathrm{pH}$ values for selected streams.

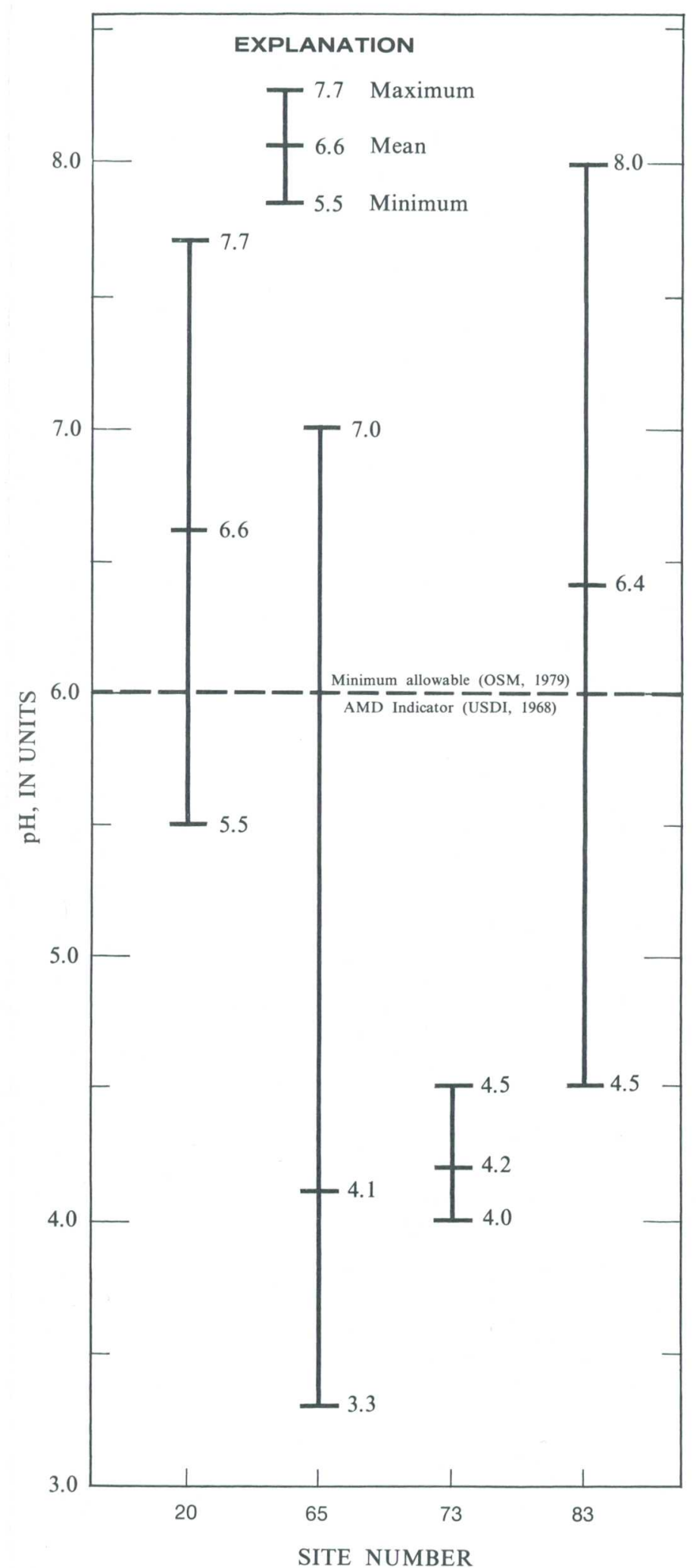

Figure 7.3-3 Ranges and means of $\mathrm{pH}$ at selected

continuous-record stations, 1976 and 1977 water years.

7.0 SURFACE-WATER QUALITY (CONTINUED) 


\title{
7.0 SURFACE-WATER QUALITY (Continued) \\ 7.4 Acidity and Alkalinity
}

\section{ACIDITY EXCEEDS ALKALINITY AT 16 of 71 SITES}

\author{
At 16 of 71 sites in Area 3, acidity exceeded \\ alkalinity. Maximum measured acidity was compared with \\ minimum measured alkalinity at each site.
}

When maximum measured acidity was compared with minimum measured alkalinity, 16 of 71 streams showed acidity in excess of alkalinity. Streams having acidity in excess of alkalinity had accompanying low $\mathrm{pH}$ values.

Figure 7.4-1 illustrates that streams having acidity in excess of alkalinity are found in three general sections of Area 3. These areas are located northeast of Butler, northeast of Pittsburgh, and north of Johnstown, respectively.
Acidity and alkalinity determinations were made for each of 72 sites in Area 3 during June 1979 to April 1980. Most sites were tested once during high base flow and twice during intermediate base flow. The alkalinities were measured in the field, but the acidity was a laboratory determination (Skougstad and others, 1979). Data for the 1979 and 1980 water years are published by the U.S. Geological Survey $(1980,1981)$. 


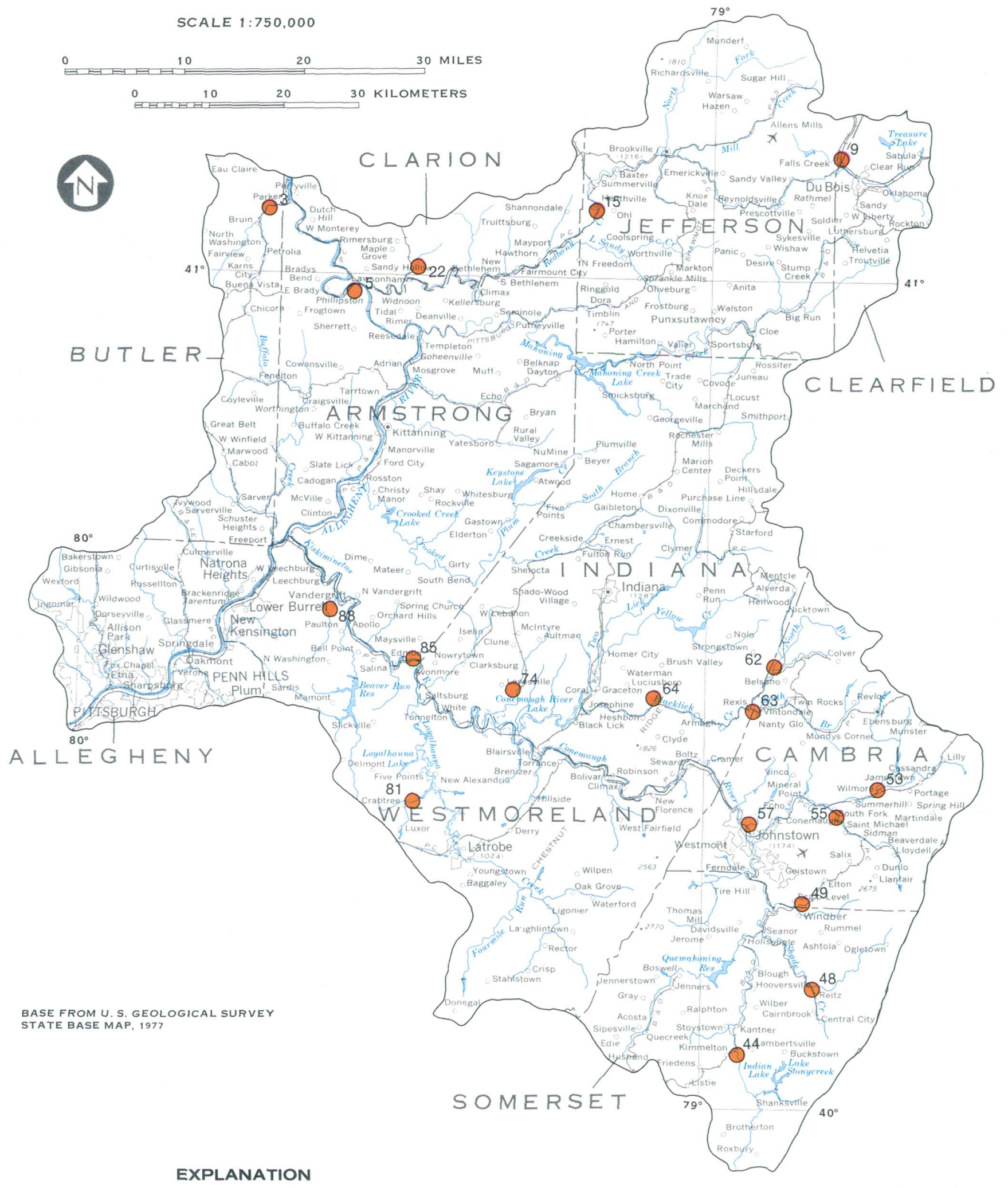

$0^{44}$ Site at which acidity exceeds alkalinity

Figure 7.4-1 Synoptic sites having acidity in excess of alkalinity. 


\title{
HIGHEST TOTAL-IRON CONCENTRATIONS MOST COMMON IN THE CONEMAUGH RIVER BASIN
}

\author{
The highest total-iron concentrations were most common \\ in the Conemaugh River basin in Area 3. Maximum total- \\ iron concentrations for sites in the area ranged from \\ $180 \mu \mathrm{g} / \mathrm{L}$ (micrograms per liter) to $160,000 \mu \mathrm{g} / \mathrm{L}$.
}

Figure 7.5-1 illustrates that the highest total-iron concentrations were found in streams in the Conemaugh River basin of Eastern Coal Province Area 3. The lower Kiskiminetas River basin and the Redbank Creek basin also had streams with high total-iron concentrations.

The maximum total-iron concentrations at sites in the area ranged from a low of $180 \mu \mathrm{g} / \mathrm{L}$ to a high of $160,000 \mu \mathrm{g} / \mathrm{L}$. The mean maximum total-iron concentration was about $8,800 \mu \mathrm{g} / \mathrm{L}$ while the median maximum concentration was $2,000 \mu \mathrm{g} / \mathrm{L}$. The difference between the mean and median maximum total-iron concentrations can be attributed to 11 streams having maximum total-iron concentrations greater than $10,000 \mu \mathrm{g} / \mathrm{L}$. Figure 7.5-2 shows that 23 streams had maximum total-iron concentrations of less than $1,000 \mu \mathrm{g} / \mathrm{L}$ and 49 streams had concentrations less than 3,000 $\mu \mathrm{g} / \mathrm{L}$. Only 11 streams had maximum total-iron concentrations greater than $9,000 \mu \mathrm{g} / \mathrm{L}$.

The distribution of maximum dissolved iron in Area 3 streams followed the same pattern as that of total iron. Maximum dissolved-iron concentrations ranged from 30 to $150,000 \mu \mathrm{g} / \mathrm{L}$, and the median maximum concentration was $240 \mu \mathrm{g} / \mathrm{L}$.

Water samples for total- and dissolved-iron determinations (Skougstad and others, 1979) were collected at 73 stream sites in Area 3 during June 1979 to April 1980. Generally one sample was collected during high base flow and two samples were collected during intermediate base flow. Future plans include low base flow sampling. Total- and dissolved-iron data for the 1979 and 1980 water years are published by the U.S. Geological Survey (1980, 1981).

The relation between total iron and dissolved iron can be seen in equation 7.5-1 and graphically in figure 7.5-3.

$$
\mathrm{TI}=1.07(\mathrm{DI})+1055
$$

Where $\mathrm{TI}=$ total-iron concentration, in micrograms per liter, and $\mathrm{DI}=$ dissolved-iron concentration, in micrograms per liter.

This equation explains 98 percent of the variation in the total iron concentration. The standard error of the estimate for the equation 7.5-1, based upon 199 data sets, is $2,400 \mu \mathrm{g} / \mathrm{L}$ total iron, or about 50 percent of the mean total-iron concentration for the 199 samples. Such a large error indicates that additional independent variables may improve the equation.

Because the difference between the total-iron concentration and the dissolved-iron concentration is the suspended-iron concentration, the suspendedsediment concentration was tried as an additional variable. The inclusion of the suspended-sediment concentration did nothing to improve the percentage of explained variation or the standard error of the estimate.

Figure 7.5-4 shows the stream-to-stream and within stream variability in total-iron concentrations at four selected continuous-record stations. Although the mean total-iron concentrations varied among the streams by a factor of $8(1,620$ to 13,400 $\mu \mathrm{g} / \mathrm{L}$ ), the concentration observed at site 20 varied by a factor of $60(140$ to $8,880 \mu \mathrm{g} / \mathrm{L})$. Sites 20 and 83 had statistically equal means as did sites 65 and 73 . All other station comparisons showed statistical differences between the means. The mean total-iron concentrations for all streams exceeded the AMD indicator level of $500 \mu \mathrm{g} / \mathrm{L}$ (U.S. Department of the Interior, 1968). The mean concentrations at sites 20 and 83 were within the 30 -consecutive day average effluent standard of $3,500 \mu \mathrm{g} / \mathrm{L}$ proposed by OSM (1979), but the mean total-iron concentrations at sites 65 and 73 exceeded even the maximum allowable effluent standard of $7,000 \mu \mathrm{g} / \mathrm{L}$ proposed by OSM (1979). 
SCALE $1: 750,000$

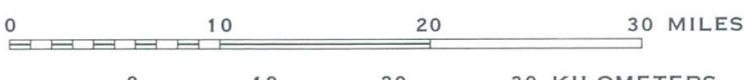
30 KILOMETERS

N

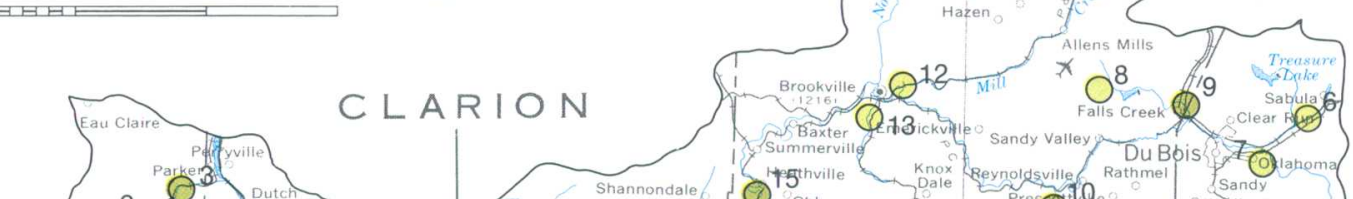

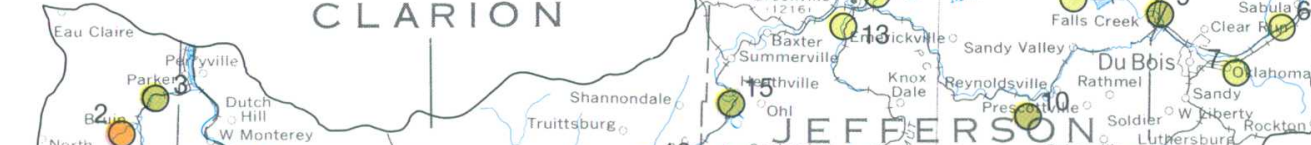

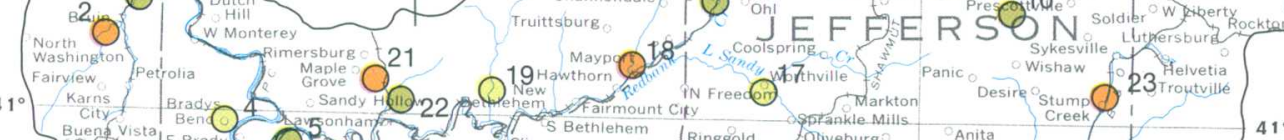

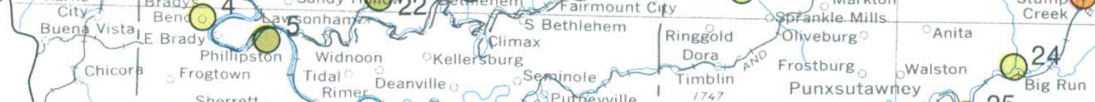

$B \cup T L E R-$

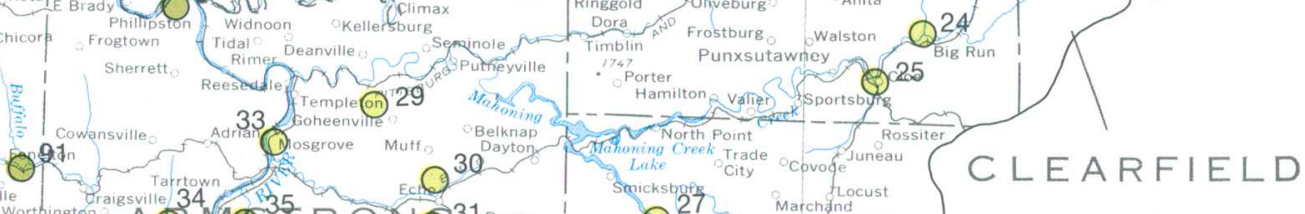

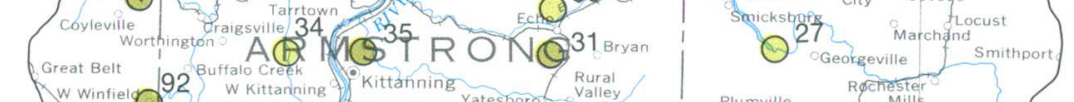

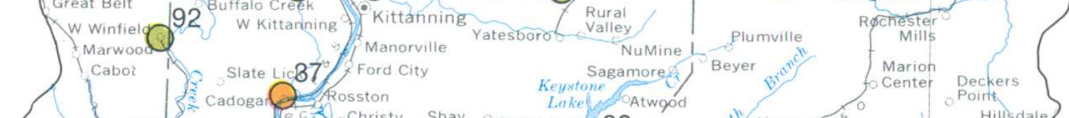

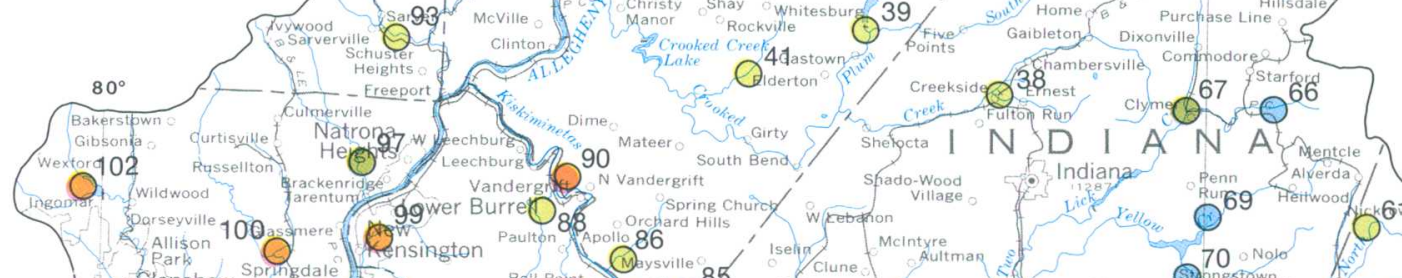

$$
\hat{s}
$$

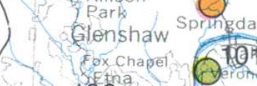

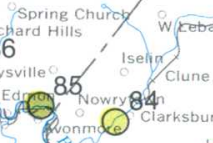

$$
\text { Syfispugaty }
$$

$A L L \stackrel{80^{\circ}}{E} G H E N Y$
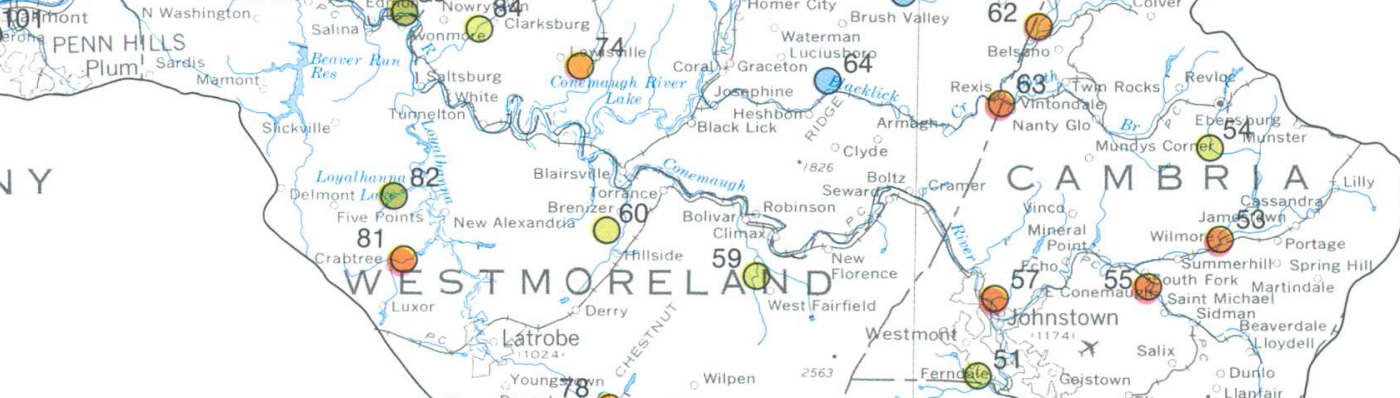

BASE FROM U. S. GEOLOGICAL SURVEY
STATE BASE MAP, 1977

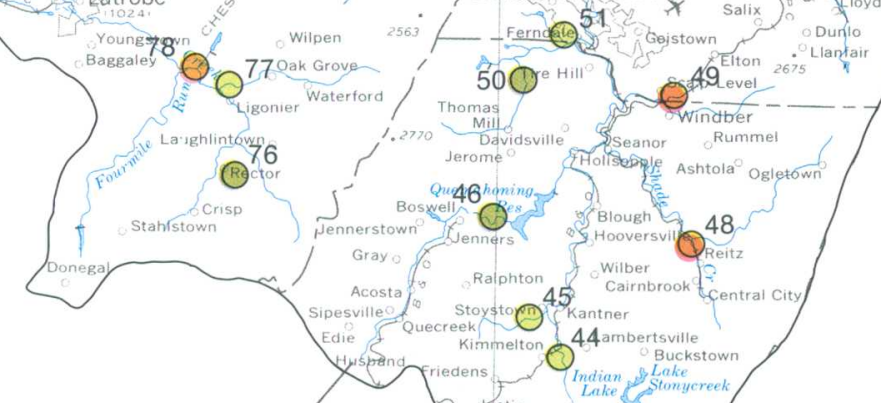

EXPLANATION

SOMERSET

Site location Maximum total-iron concentratio

and number in micrograms per liter

$$
\bigcirc^{64} \quad \mathbf{0 - 4 9 9}
$$

$\mathrm{O}^{45} \quad \mathbf{5 0 0 - 1 , 9 9 9}$

$\mathrm{O}^{46} \quad \mathbf{2 , 0 0 0 - 4 , 9 9 9}$

$\bigcirc^{2} \quad 5,000-19,999$

$\mathrm{O}^{48} \quad \mathbf{2 0 , 0 0 0 +}$

Figure 7.5-1 Maximum total-iron concentrations for selected streams.
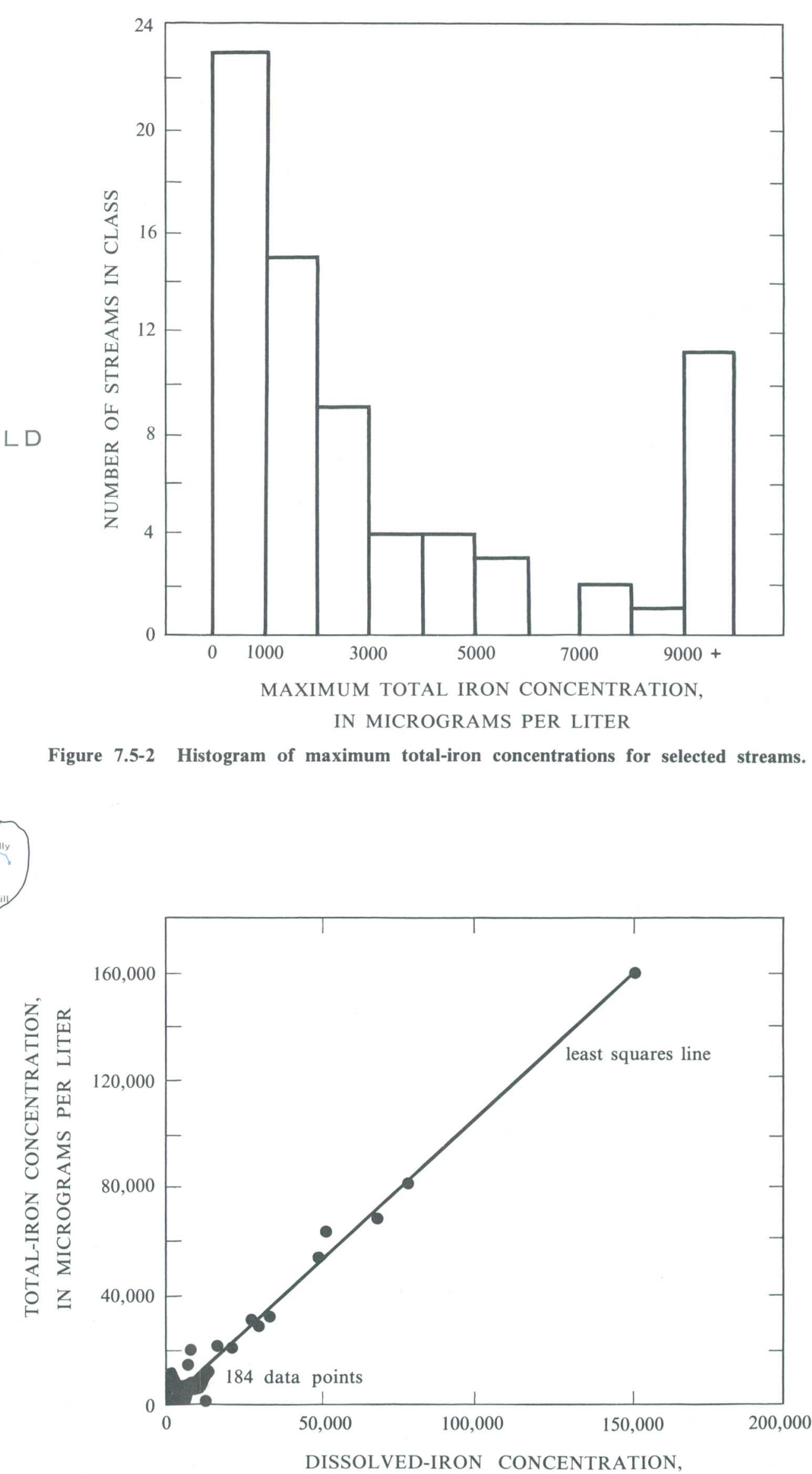

IN MICROGRAMS PER LITER

Figure 7.5-2 Histogram of maximum total-iron concentrations for selected streams.

DISSOLVED-IRON CONCENTRATION,

IN MICROGRAMS PER LITER

Figure 7.5-3 Relation between dissolved- and total-iron concentrations for selected streams.

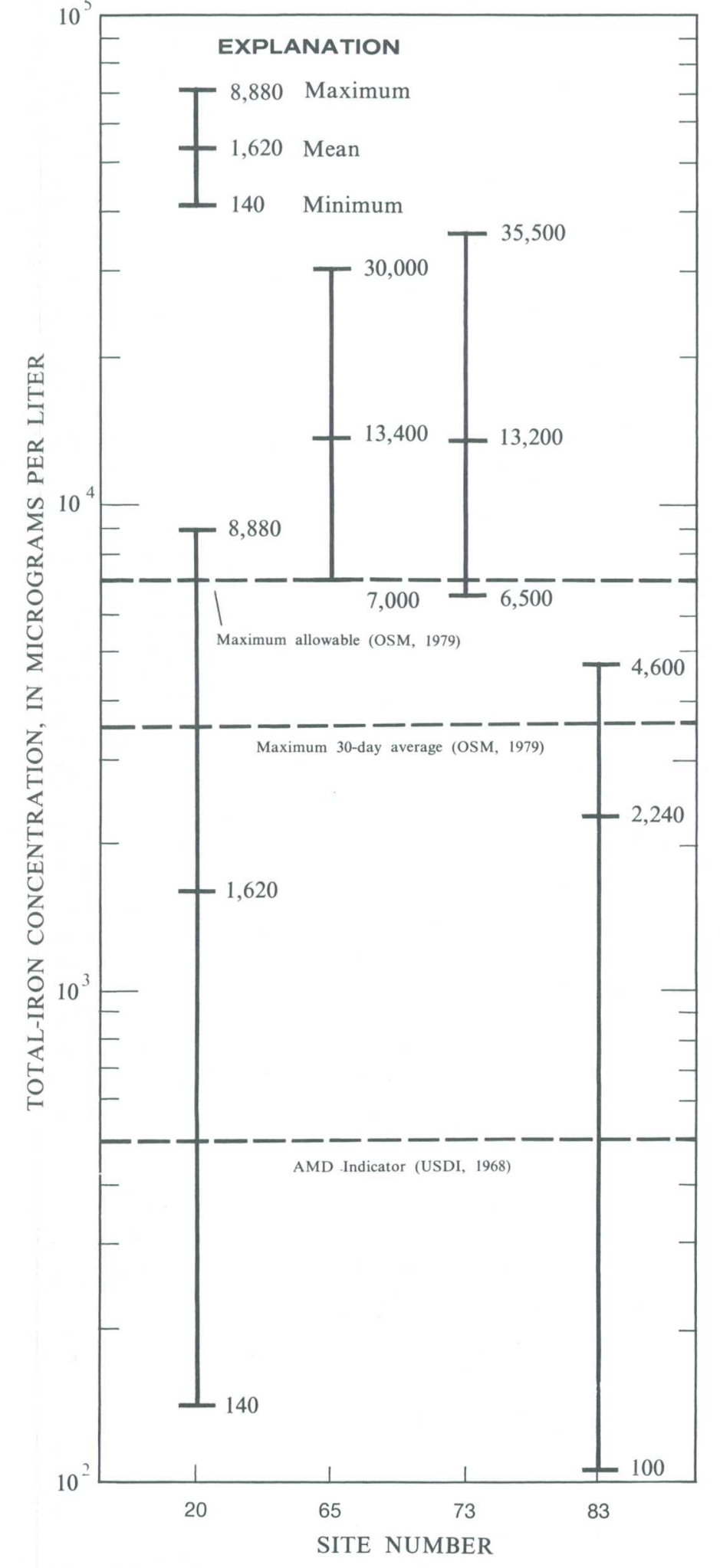

Figure 7.5-4 Ranges and means of total-iron concentrations at selected continuous-record stations, 1976 and 1977 water years.

7.0 SURFACE-WATER QUALITY (CONTINUED) 7.5 TOTAL AND DISSOLVED IRON 


\title{
HIGH TOTAL-MANGANESE CONCENTRATIONS WERE MOST COMMON IN FOUR DRAINAGE BASINS
}

\author{
High total-manganese concentrations in Area 3 were \\ found in the Redbank Creek, Blacklick Creek, Conemaugh \\ River, and lower Kiskiminetas River basins. Maximum total- \\ manganese concentrations at sites in the area ranged from \\ 40 to $32,000 \mu \mathrm{g} / \mathrm{L}$ (micrograms per liter).
}

Figure 7.6-1 illustrates that the highest totalmanganese concentrations found in streams in Eastern Coal Province Area 3 were generally confined to four drainage basins. One drainage basin having streams with high total-manganese concentrations is the Redbank Creek basin, located northeast of Butler. A second basin having high concentrations is the lower Kiskiminetas River basin in the vicinity of Vandergrift. The third and fourth basins are the Blacklick Creek and upper Conemaugh River basins, located north and south of Johnstown, respectively.

The maximum total-manganese concentrations found at 73 stream sites ranged from a low of $40 \mu \mathrm{g} /$ $\mathrm{L}$ to a high of $32,000 \mu \mathrm{g} / \mathrm{L}$. The mean maximum total-manganese concentration was $1,710 \mu \mathrm{g} / \mathrm{L}$ and the median maximum concentration was $420 \mu \mathrm{g} / \mathrm{L}$. The difference between the mean and median concentrations results from eight streams having totalmanganese concentrations in excess of $4,000 \mu \mathrm{g} / \mathrm{L}$. Figure 7.6-2 shows that 22 streams had concentrations in excess of $1,000 \mu \mathrm{g} / \mathrm{L}$.

The distribution of maximum dissolved manganese in Area 3 streams followed the same pattern as that of total manganese. Maximum dissolvedmanganese concentrations ranged from 20 to 32,000 $\mu \mathrm{g} / \mathrm{L}$, and the median maximum concentration was $390 \mu \mathrm{g} / \mathrm{L}$.

Water samples for total- and dissolved-manganese determinations (Skougstad and others, 1979) were collected at 73 stream sites during June 1979 to April 1980. Generally one sample was collected during high base flow and two samples collected during intermediate base flow. Future plans include low base-flow sampling. Total- and dissolved-manganese data for the 1979 and 1980 water years are published by the U.S. Geological Survey $(1980,1981)$.
The relation between total-inanganese concentration and dissolved-manganese concentration is shown in equation 7.6-1 and graphically in figure 7.6-3.

$$
\mathrm{TM}=0.98(\mathrm{DM})+18 \quad(7.6-1)
$$

Where $\mathrm{TM}=$ total-manganese concentration, in micrograms per liter, and

$\mathrm{DM}=$ dissolved-manganese concentration, in micrograms per liter.

This equation explains 99 percent of the variation in the total-manganese concentration. The standard error of the estimate for equation 7.6-1, based on 204 data sets, is $193 \mu \mathrm{g} / \mathrm{L}$ total manganese or about 20 percent of the mean total-manganese concentration for the 204 samples. As in the case of total iron, the addition of suspended-sediment concentration to the regression equation did nothing to improve the estimate of total manganese.

Mean total-manganese concentrations at three selected continuous-record stations ranged from 809 to $1,220 \mu \mathrm{g} / \mathrm{L}$ during the 1976 and 1977 water years (fig. 7.6-4), but none of the means were statistically different. The variation in total-manganese concentration at individual stations ranged from a factor of 2 for site 73 , to a factor of 11 for site 83 , to a factor of 22 for site 65 (fig. 7.6-4). Figure 7.6-4 also indicates that the mean total-manganese concentrations at all the stations, although exceeding the U.S. Department of the Interior (1968) AMD indicator level of $500 \mu \mathrm{g} / \mathrm{L}$, are well within the OSM (1979) 30 -consecutive day average effluent standard of $2,000 \mu \mathrm{g} / \mathrm{L}$. 


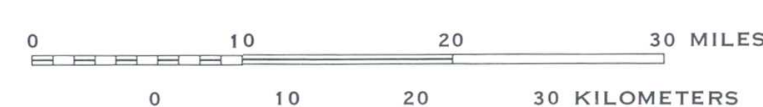

30 MLES

(1)

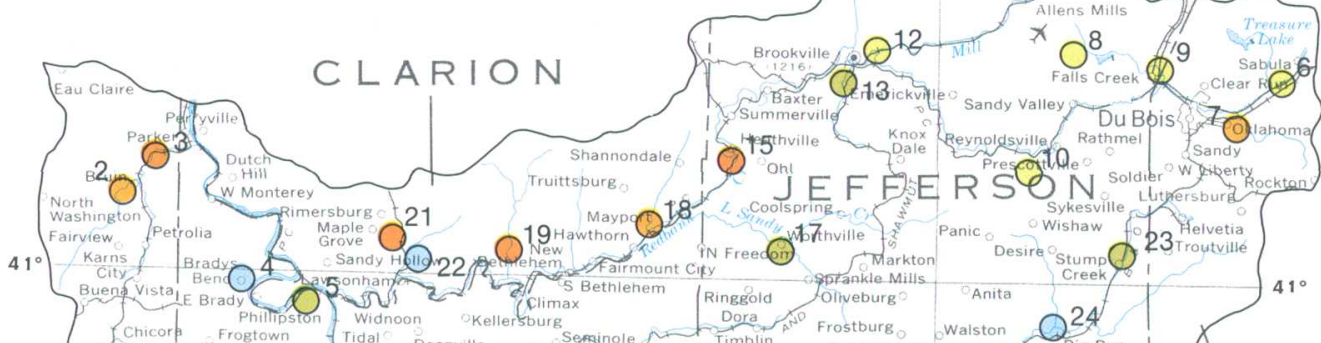

B U T LER

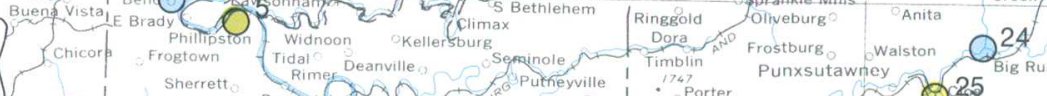

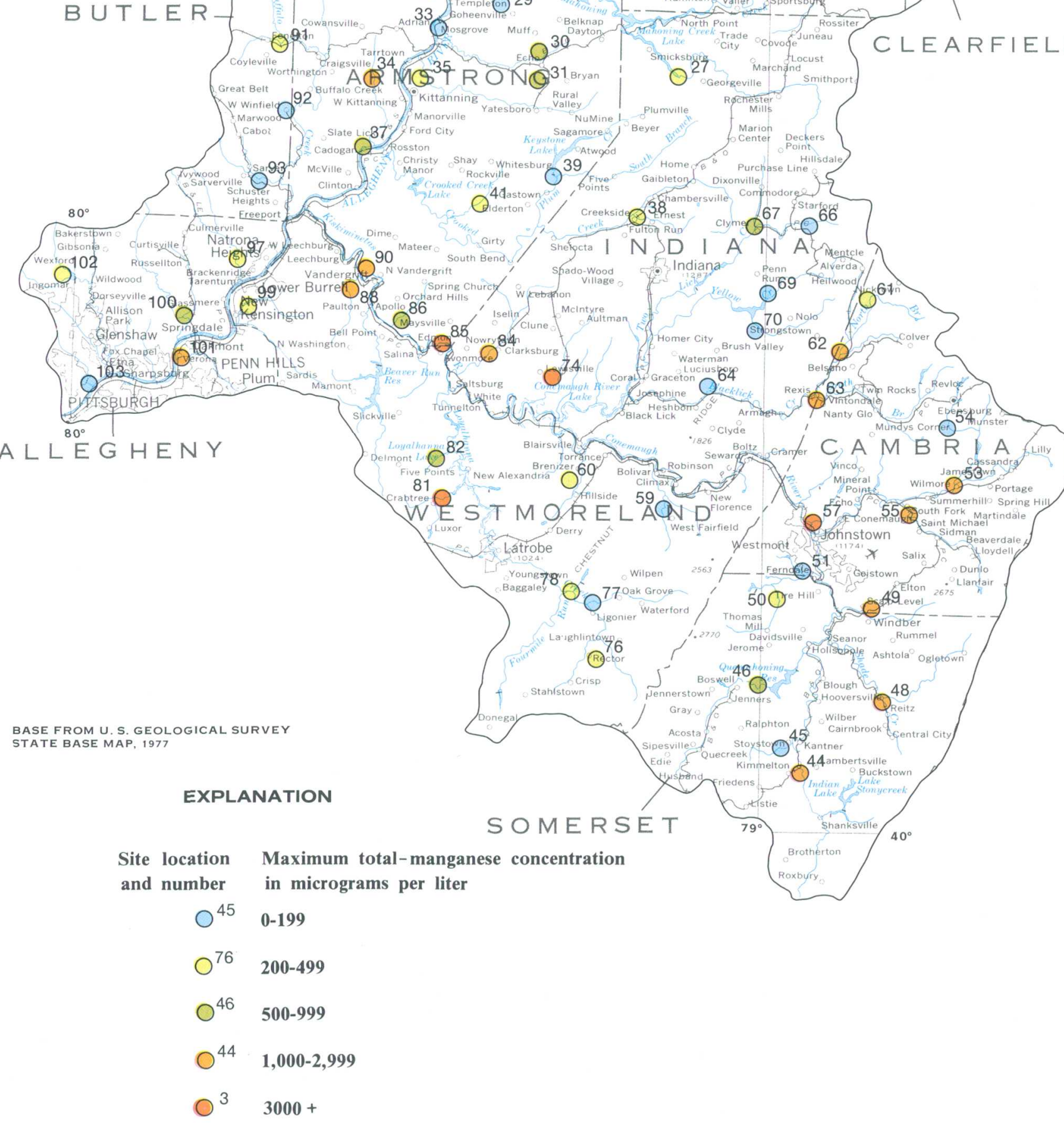

Figure 7.6-1 Maximum total-manganese concentrations for selected streams

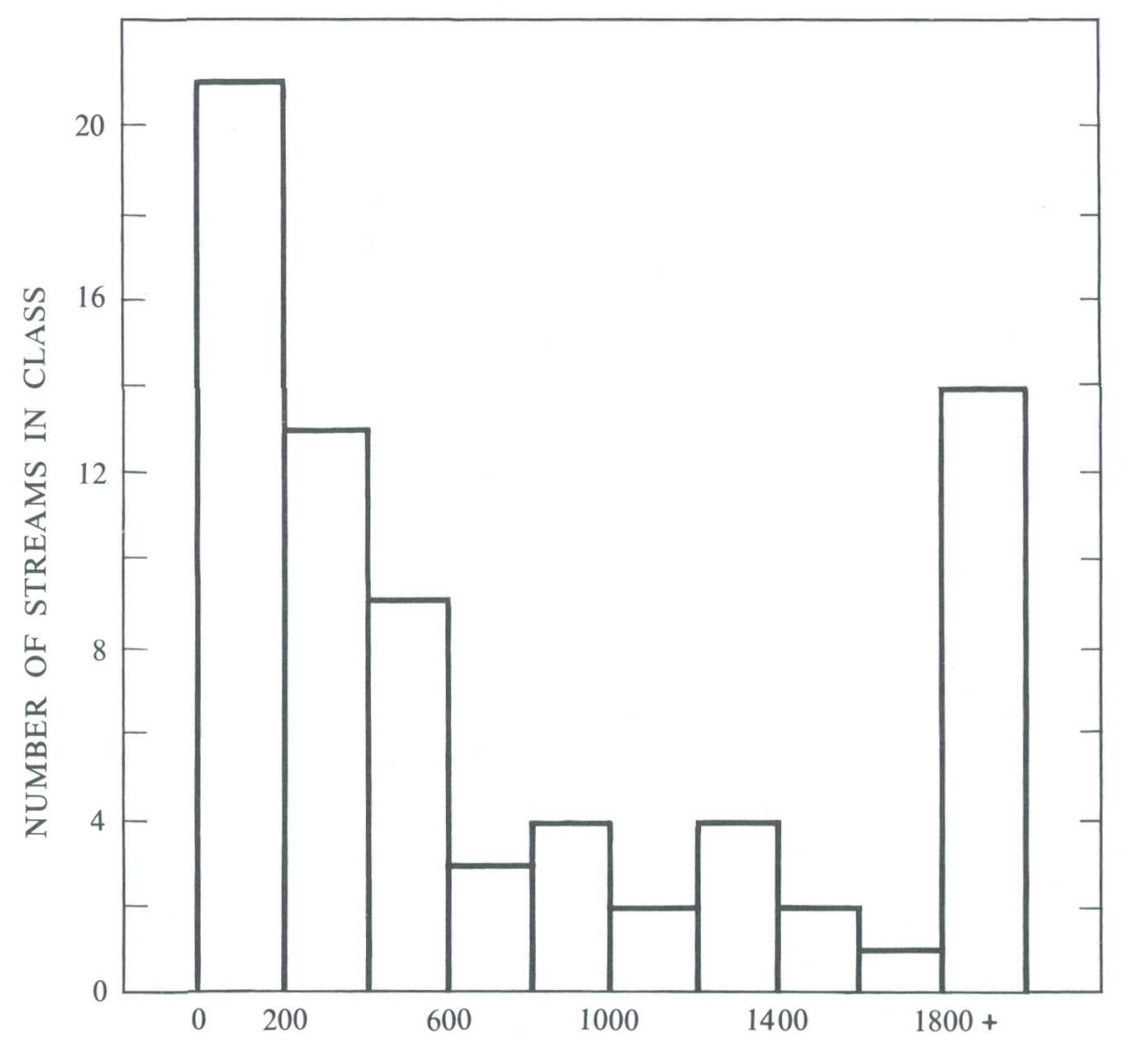

MAXIMUM TOTAL-MANGANESE CONCENTRATION, IN MICROGRAMS PER LITER

Figure 7.6-2 Maximum total-manganese concentrations for selected streams.

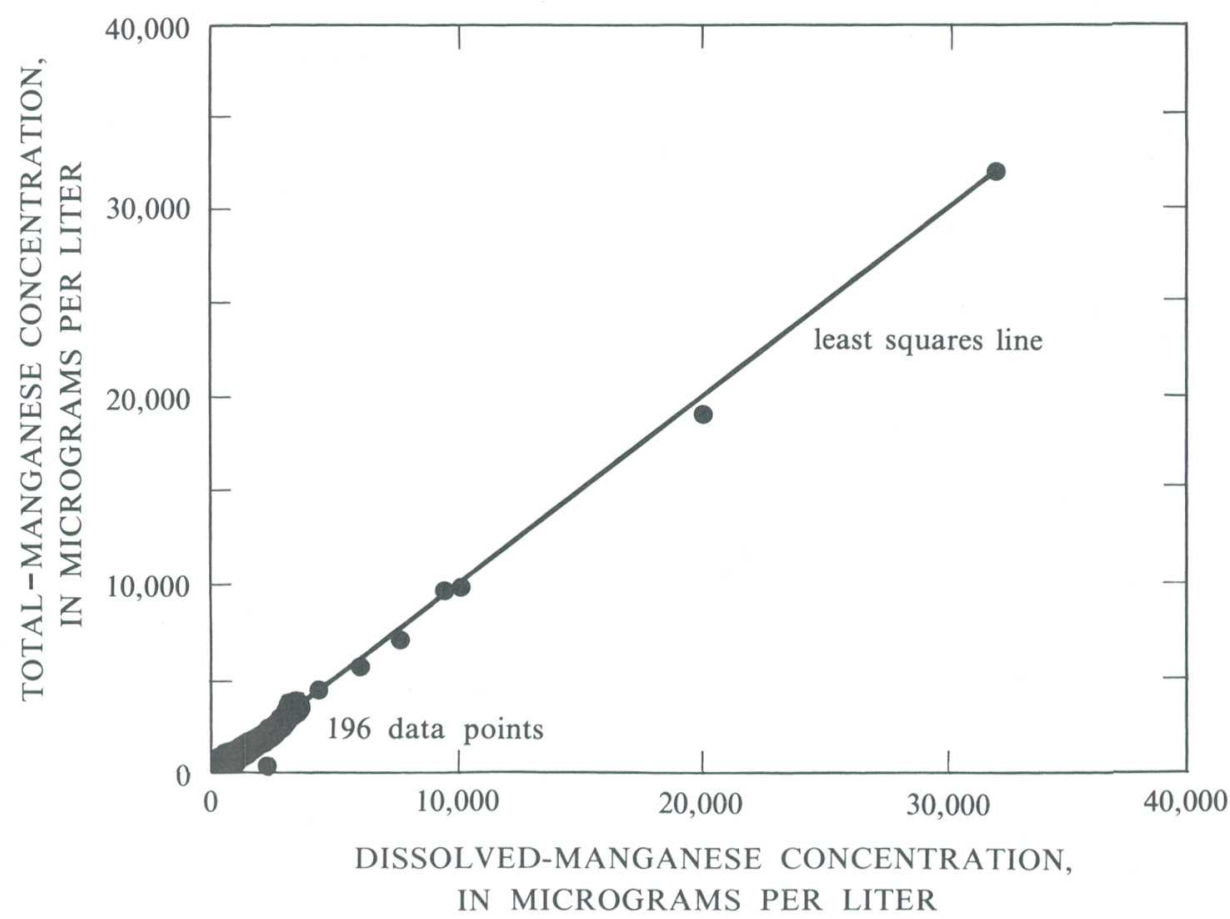

concentrations for selected streams.

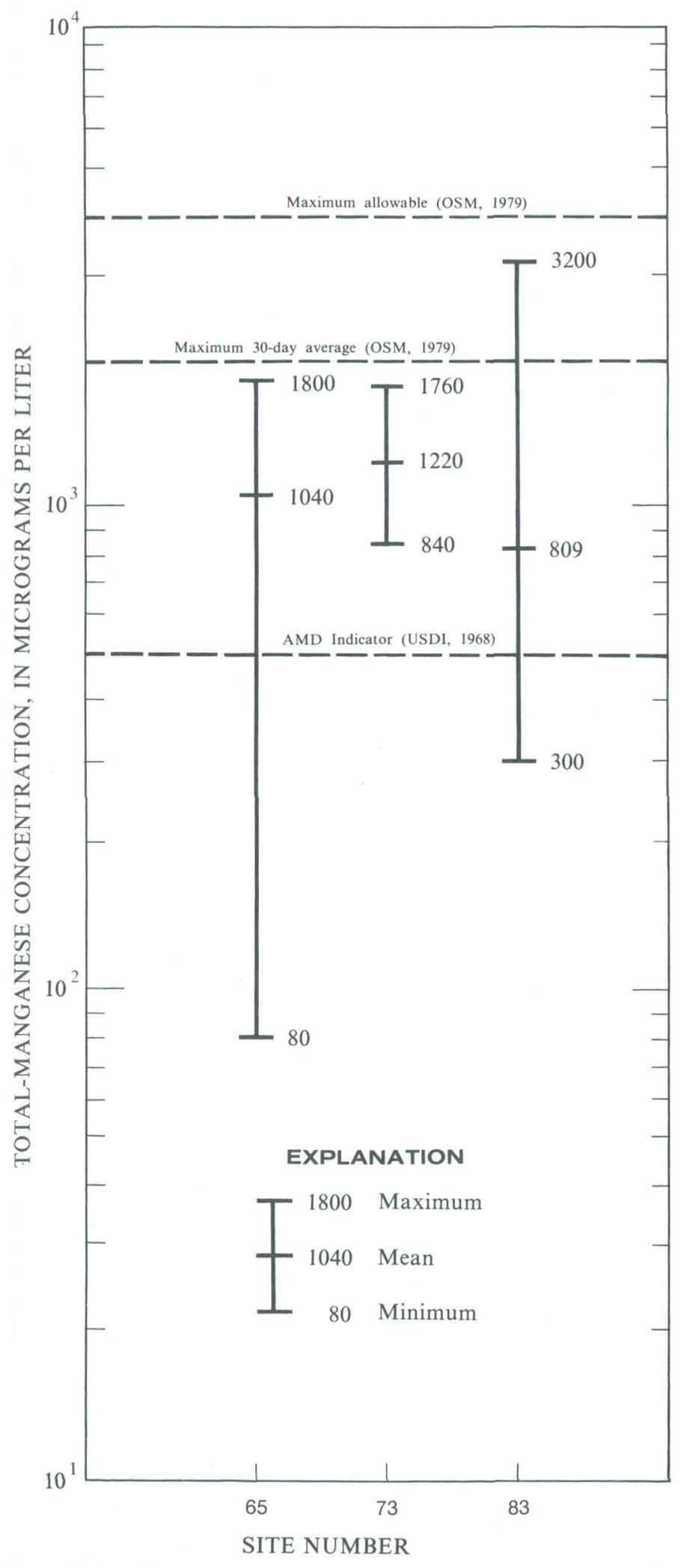

Figure 7.6-4 Ranges and means of total-manganese concentrations at selected continuous-record stations, 1976 and 1977 water years.

7.0 SURFACE-WATER QUALITY (CONTINUED) 7.6 TOTAL AND DISSOLVED MANGANESE 


\title{
7.0 SURFACE-WATER QUALITY (Continued) \\ 7.7 Dissolved Sulfate
}

\section{HIGH DISSOLVED-SULFATE CONCENTRATIONS WERE MOST COMMON IN FIVE DRAINAGE BASINS}

\author{
The highest dissolved-sulfate concentrations in \\ Area 3 were found in the Redbank Creek, Blacklick \\ Creek, Conemaugh River, and lower Kiskiminetas River \\ basins, and in tributaries to the Allegheny River \\ downstream from the Kiskiminetas River. Maximum dissolved- \\ sulfate concentrations in the Area ranged from 11 to $1,900 \mathrm{mg} / \mathrm{L}$ \\ (milligrams per liter).
}

Figure 7.7-1 illustrates that the highest dissolved-sulfate concentrations in streams of Eastern Coal Province Area 3 were generally found in five drainage basins. One drainage basin having dissolved-sulfate concentrations in excess of 300 $\mathrm{mg} / \mathrm{L}$ is the Redbank Creek basin, located northeast of Butler. A second basin having high sulfate concentrations is the lower Kiskiminetas River basin in the vicinity of Vandergrift. The third and fourth basins are the Blacklick Creek and upper Conemaugh River basins, located north and south of Johnstown, respectively. High sulfate concentrations were also found in tributaries to the Allegheny River downstream from the mouth of the Kiskiminetas River.

The maximum dissolved-sulfate concentrations found at 73 stream sites ranged from a low of 11 $\mathrm{mg} / \mathrm{L}$ to a high of $1,900 \mathrm{mg} / \mathrm{L}$. The mean maximum dissolved-sulfate concentration was $290 \mathrm{mg} / \mathrm{L}$ and the median concentration was $130 \mathrm{mg} / \mathrm{L}$. The large difference between the mean and median concentrations resulted from a small number of relatively high sulfate concentrations. Figure 7.7-2 indicates that 30 streams had a maximum dissolved-sulfate concentra- tion of less than $100 \mathrm{mg} / \mathrm{L}$ while 12 streams had concentrations greater than $500 \mathrm{mg} / \mathrm{L}$.

Water samples for dissolved-sulfate determinations (Skougstad and others, 1979) were collected at 73 stream sites during June 1979 to April 1980. Generally one sample was collected during high base flow and two samples collected during intermediate base flow. Future plans include low base-flow sampling. Dissolved sulfate data for the 1979 and 1980 water years are published by the U.S. Geological Survey $(1980,1981)$.

Mean dissolved-sulfate concentrations in four selected continuous-record stations ranged from 88 to $263 \mathrm{mg} / \mathrm{L}$ (fig. 7.7-3). Most of the comparisons between the means for the streams showed no significant differences. The only exceptions were when comparing site 20 with site 73 and site 65 with site 73 . The mean dissolved-sulfate concentration for each of the selected streams was greater than the U.S. Department of the Interior's (1968) AMD (acid-mine drainage) indicator of $75 \mathrm{mg} / \mathrm{L}$. 


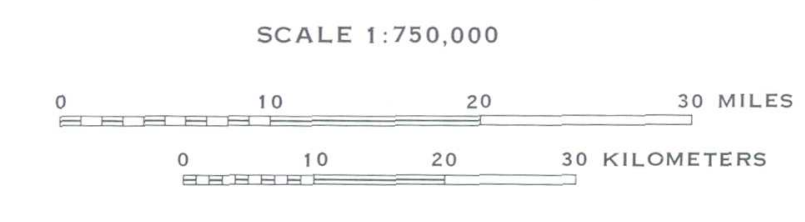

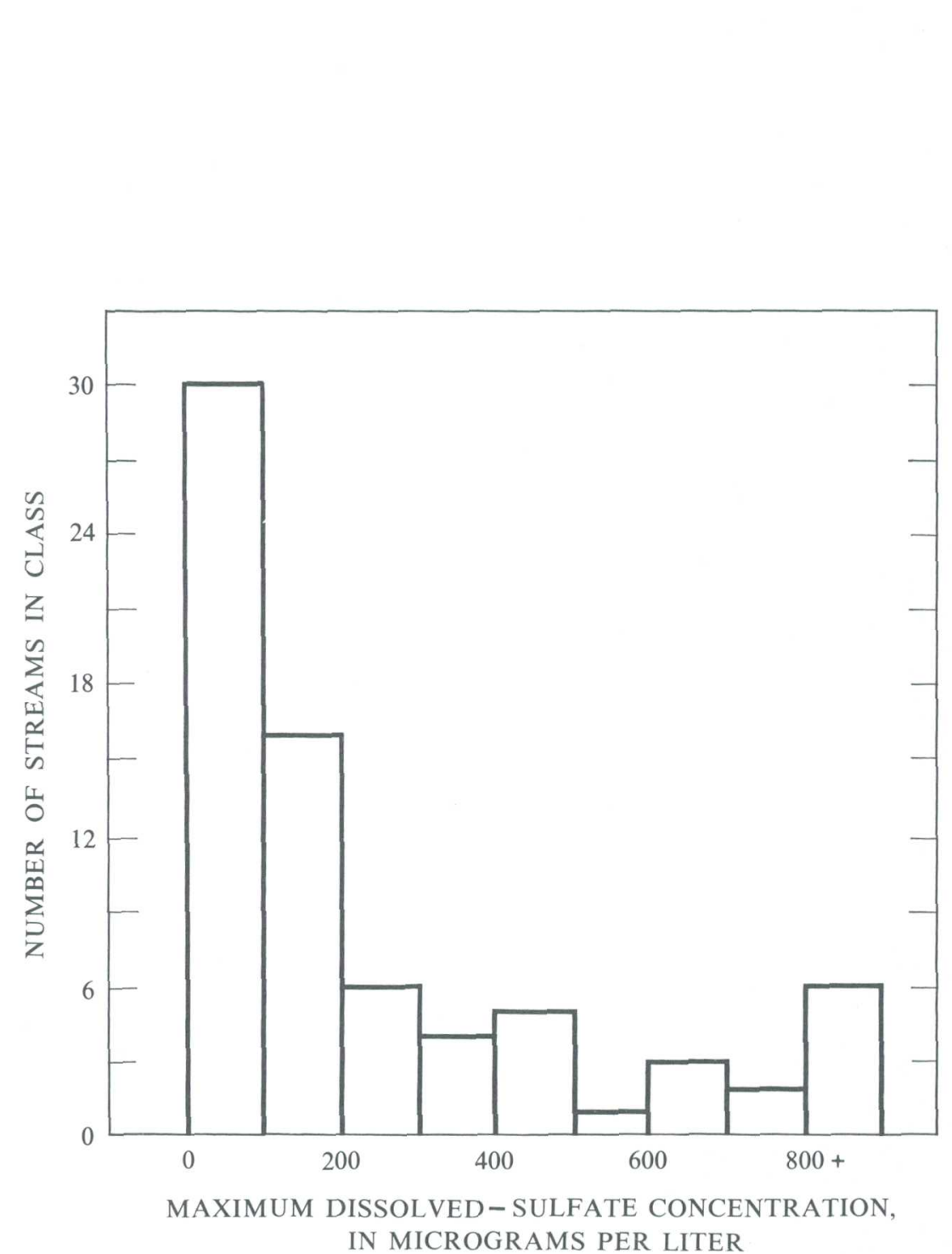

Figure 7.7-2 Maximum dissolved-sulfate concentrations for selected streams.

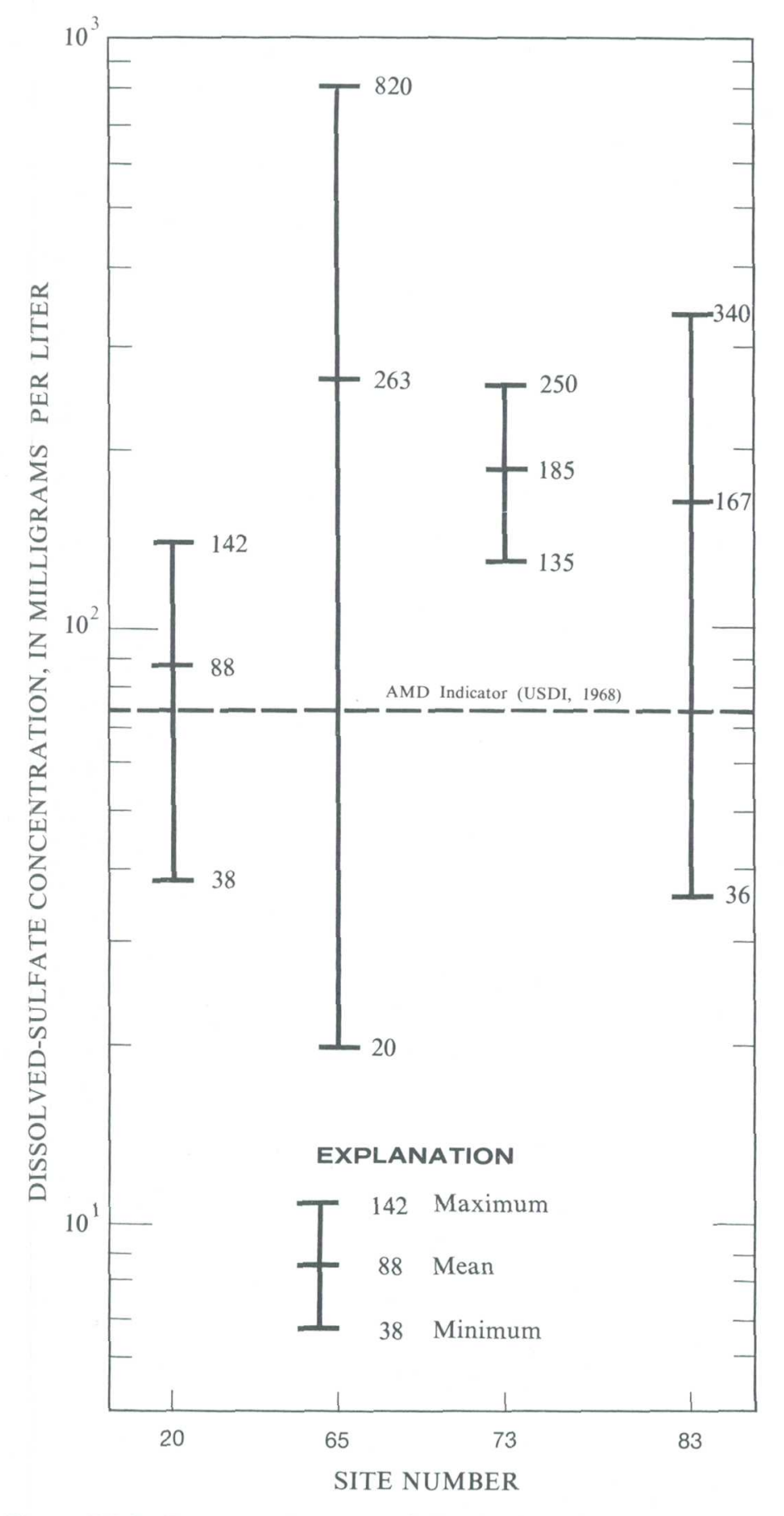

Figure 7.7-3 Ranges and means of dissolved-sulfate concentrations at selected continuour-record stations, 1976 and 1977 water years.

7.0 SURFACE-WATER QUALITY (CONTINUED) 7.7 DISSOLVED SULFATE 


\title{
7.0 SURFACE-WATER QUALITY (Continued) \\ 7.8 Suspended Sediment
}

\section{SUSPENDED-SEDIMENT DISCHARGE RELATED TO STREAMFLOW}

\author{
Suspended-sediment discharges in Area 3 streams \\ are related to streamflow, but the relationship \\ shows wide variations. The variations are not \\ related to the presence of AMD (acid-mine \\ drainage) indicators.
}

Figure 7.8-1 illustrates the suspended-sediment transport data derived from 207 samples at the 73 synoptic sites in Eastern Coal Province Area 3. This particular graph relates instantaneous suspendedsediment discharge in tons to instantaneous streamflow in $\left(\mathrm{ft}^{3} / \mathrm{s}\right) / \mathrm{mi}^{2}$ (cubic feet per second per square mile). The shaded portion of figure 7.8-1 encloses 98 percent of the data collected at synoptic sites in Area 3 . Note that these data show that for any given instantaneous unit discharge the instantaneous suspended-sediment discharge may vary by a factor of 1,500 . This variability is about 30 times that shown by Wark (1965) for samples from a single large river. The sediment-transport envelope illustrated in figure 7.8-1 should indicate the range of suspended-sediment discharge for most streams in Area 3 having drainage areas between 2.5 and 90 square miles. The large variability may reflect the wide range of land use in the sampled basins.

Porterfield (1972) states that an instantaneous transport curve may agree, in practice, with a daily transport curve. If this is the case, it should be possible to compute average annual suspended-sediment discharge using the flow-duration transport-curve method described by Miller (1951). Under this assumption a minimum annual suspended-sediment discharge for Area 3 streams was computed as shown in table 7.8-1. Average water discharges per square mile for selected time intervals were determined from a composite flow-duration curve for streams in Area 3 (fig. 7.8-2). The development of the composite flow-duration curve is discussed in section 9.5.2. Minimum suspended-sediment discharges corresponding to the selected discharges were determined from the composite suspended-sediment transport curve for Area 3 streams (fig. 7.8-1) and multiplied by the duration intervals of water discharge to calculate the average annual sediment load. For example, the average water discharge for Area 3 streams for
8.5 to 15 percent of the time is $3.7\left(\mathrm{ft}^{3} / \mathrm{s}\right) / \mathrm{mi}^{2}$. The corresponding suspended-sediment discharge is 0.03 tons $/ \mathrm{mi}^{2}$ (tons per square mile). Multiplying the suspended sediment discharge by the time interval for each interval in table 7.8-1 and dividing the sum of column 6 by 100 (table 7.8-1) yields the mean daily suspended-sediment discharge in tons $/ \mathrm{mi}^{2}$. Multiplying the mean daily suspended-sediment discharge by 365 yields the minimum annual suspended-sediment discharge in tons $/ \mathrm{mi}^{2}$.

Table 7.8-1 indicates that the minimum annual suspended-sediment discharge for streams in Area 3 would be about 7 tons $/ \mathrm{mi}^{2}$. Wark (1965) states that the average annual suspended-sediment yield in Area 3 ranges from $20-250$ tons $/ \mathrm{mi}^{2}$. Wark's 1965 figures indicate that the average suspended-sediment concentration would range from $12-150 \mathrm{mg} / \mathrm{L}$ (milligrams per liter). The concentrations are computed using an average discharge of $1.7\left(\mathrm{ft}^{3} / \mathrm{s}\right) / \mathrm{mi}^{2}$ which is applicable for Area 3 streams. Because relatively large amounts of sediment move in relatively short periods of storm runoff (Wark, 1965), the concentrations must be less than the average values much of the time.

Sediment-transport data for 16 streams exhibiting AMD (acid-mine drainage) indicators fell within the envelope as shown by the solid circles in figure 7.8-1. The distribution of the data was no different from that of all transport data, demonstrating that for the range of flows evaluated to date, streams containing AMD do not carry larger sediment loads than nearby non-AMD streams. There may be several reasons for this. The AMD may be coming from underground mines which normally would discharge little suspended sediment, or it may be coming from surface mines which are not presently being mined. Many of the suspended-sediment samples collected during high runoff, when most suspended-sediment 
is transported, were collected during the recession from storm runoff. In areas where much sediment is available for transport, such as surface mined areas, charges often precede the peak, and data collected during the recession may underestimate the actual spended-sediment-transport characteristics.

The streamflow- and suspended-sediment dispublished by U.S. Geological Survey $(1980,1981)$.

\section{EXPLANATION}

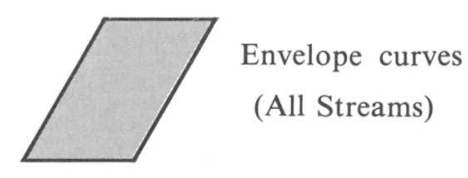

- AMD Streams

Table 7.8-1 Computsion of average antal suspended-sedime discharge using sediment-transport and flow-duration data.

\begin{tabular}{|c|c|c|c|c|c|}
\hline $\begin{array}{l}\text { Cumulative } \\
\text { Time } \\
\text { (percent) } \\
\quad(1) \\
\end{array}$ & $\begin{array}{l}\text { Time } \\
\text { Interval } \\
\text { (percent) } \\
\quad(2) \\
\end{array}$ & $\begin{array}{l}\text { Mid- } \\
\text { ordinate } \\
\text { (percent) } \\
\quad(3)\end{array}$ & $\begin{array}{l}\text { Unit } \\
\text { Discharge } \\
\left(\left[\mathrm{ft}^{3} \mathrm{~s}\right] / \mathrm{mi}^{2}\right) \\
\qquad(4)\end{array}$ & $\begin{array}{l}\text { Suspended } \\
\text { Sediment } \\
\text { Load } \\
\left(\text { tons } / \mathrm{mi}^{2}\right) \\
\quad(5)\end{array}$ & $\begin{array}{l}\text { Load for } \\
\text { Interval } \\
\left(\text { tons } / \mathrm{mi}^{2}\right)^{1} \\
(6)\end{array}$ \\
\hline 0.25 & 0.25 & 0.125 & $20^{2}$ & 1.0 & 0.25 \\
\hline .75 & .50 & .500 & $15^{2}$ & .70 & .35 \\
\hline 1.5 & .75 & 1.125 & $12^{2}$ & .20 & .15 \\
\hline 2.5 & 1.0 & 2.000 & $10^{2}$ & .12 & .12 \\
\hline 4.5 & 2.0 & 3.500 & 8.5 & .17 & .34 \\
\hline 8.5 & 4.0 & 6.500 & 6.0 & .08 & .32 \\
\hline 15 & 6.5 & 11.750 & 3.7 & .03 & .20 \\
\hline 25 & 10 & 20.000 & 2.4 & .014 & .14 \\
\hline 35 & 10 & 30.000 & 1.7 & .006 & .06 \\
\hline 45 & 10 & 40.000 & 1.2 & .003 & .03 \\
\hline 55 & 10 & 50.000 & .88 & .002 & .02 \\
\hline 75 & 20 & 65.000 & .50 & - & - \\
\hline 95 & 20 & 85.000 & .08 & ---- & --- \\
\hline 100 & 5 & 97.500 & .06 & --- & $\cdots$ \\
\hline Total & --- & ---- & ---- & ---- & 1.98 \\
\hline
\end{tabular}

Mean daily suspended-sediment discharge $=1.98 / 100=.0198$ tons $/ \mathrm{mi}^{2}$

Average annual suspended-sediment discharge $=.0198 \times 365=7.2$ tons $/ \mathrm{mi}^{2}$

1 Column $6=$ column $2 \times$ column 5

2 Estimated

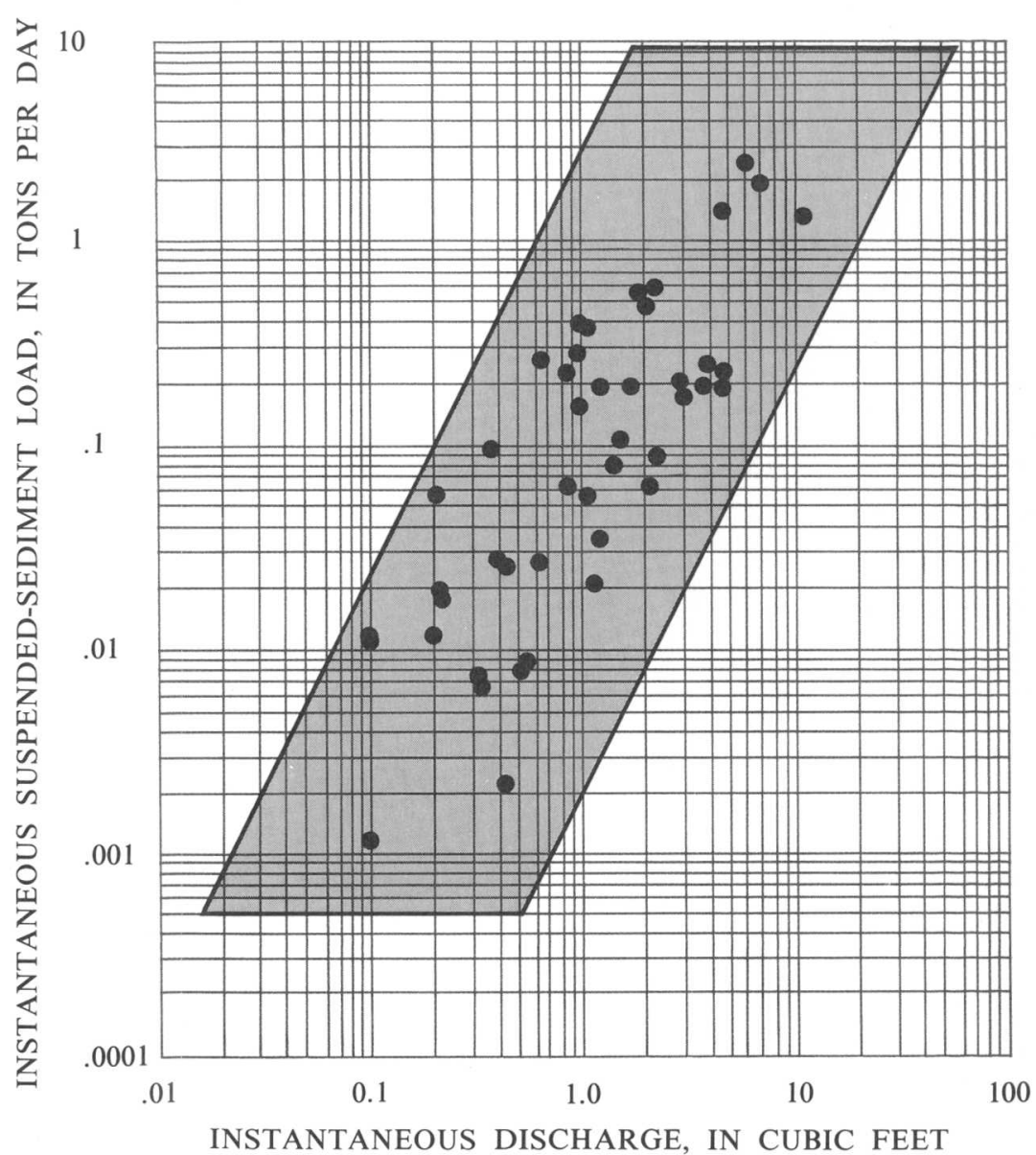

E, IN CUBIC PER SECOND PER SQUARE MILE

Figure 7.8-1 Instantaneous suspended-sediment transport in selected streams.

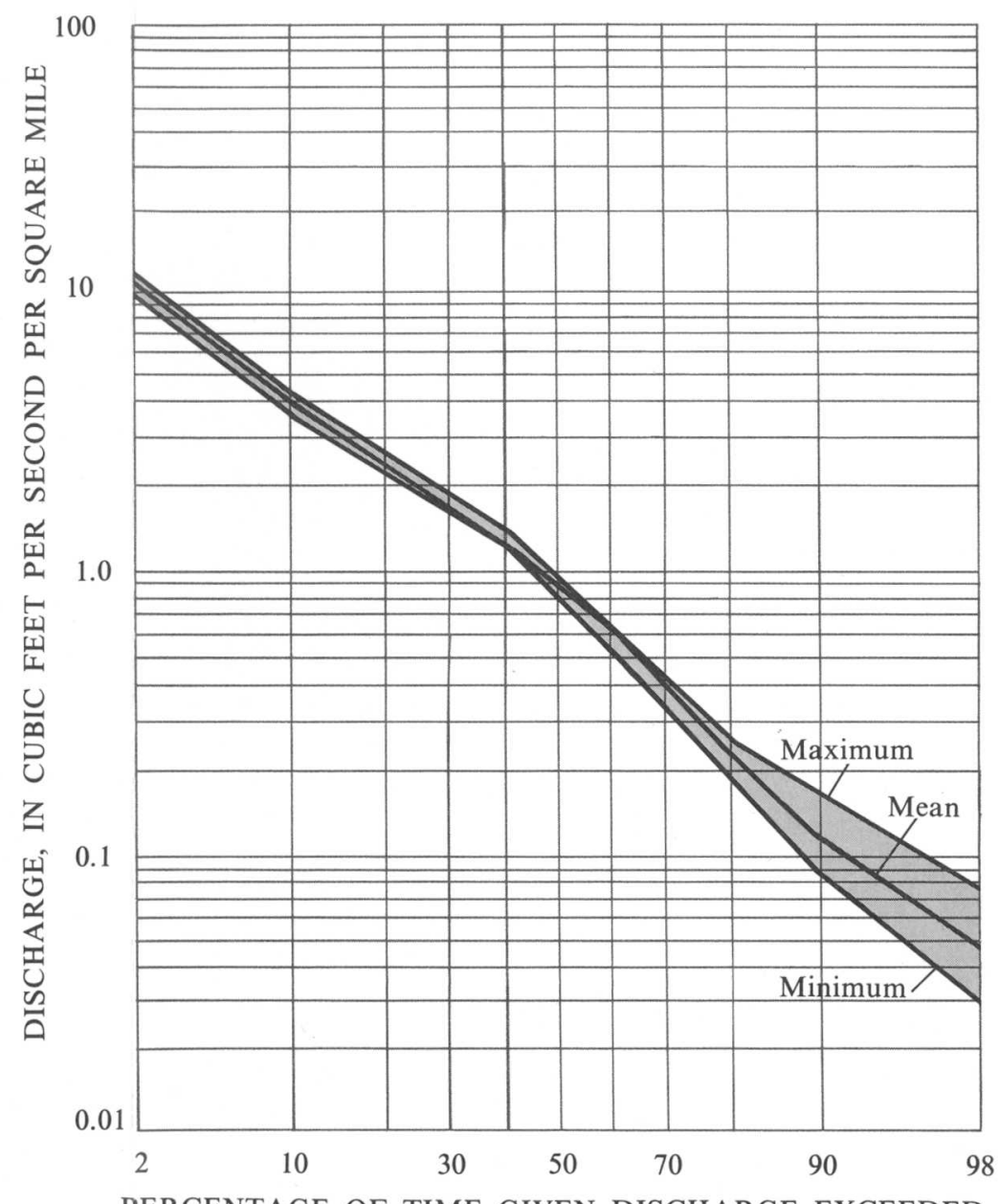

PERCENTAGE OF

Figure 7.8-2 Composite flow-duration curves. 


\author{
7.0 SURFACE-WATER QUALITY (Continued \\ 7.9 Bed Material \\ 7.9.1 Iron
}

\title{
HIGHEST IRON CONCENTRATIONS IN BED MATERIAL ARE SCATTERED ACROSS AREA
}

\author{
The highest concentration of iron in bed materials occurs \\ in the central portion of Area 3, but is not confined to \\ specific drainage basins. The iron concentrations range \\ from 4,200 to $100,000 \mu \mathrm{g} / \mathrm{g}$ (micrograms per gram).
}

Figure 7.9.1-1 indicates that the highest iron concentrations in bed material in Eastern Coal Province Area 3 are found in streams scattered across the central portion of the area. There is a slight clustering of high concentrations in the east-central portion, but it is not confined to any specific drainage basins.

Concentrations of iron in the 62 bed material samples ranged from $4,200 \mu \mathrm{g} / \mathrm{g}$ to $100,000 \mu \mathrm{g} / \mathrm{g}$. The mean concentration of iron in the bed material was $38,700 \mu \mathrm{g} / \mathrm{g}$ and the median concentration was $39,000 \mu \mathrm{g} / \mathrm{g}$. Figure 7.9.1-2 shows a relatively uniform distribution of streams among concentration ranges, except for the high and low ends. Figure 7.9.1-2 also shows that in three streams the iron concentration in the bed material was less than 10,000 $\mu \mathrm{g} / \mathrm{g}$ and in two streams the concentration was greater than $70,000 \mu \mathrm{g} / \mathrm{g}$.

Bed-material samples for iron determination
(Skougstad and others, 1979) were collected during August 1980. Bed materials may serve as historical integrators of basin conditions. As conservative materials pass through the stream channel network, they are incorporated into the bed material. Unless extremely high flows scour the bed material and carry it downstream, the deposits may serve as indicators of past water-quality conditions. Feltz (1980) states that concentrations of heavy metals found in bottom materials confirmed potential contamination in the Schuylkill River although concentrations in the water itself indicated no apparent problem. The concentrations of heavy metals in the bottom materials were several orders of magnitude higher than the concentrations in the water.

Data from the chemical analysis of bed materials are published by the U.S. Geological Survey (1980, 1981). 


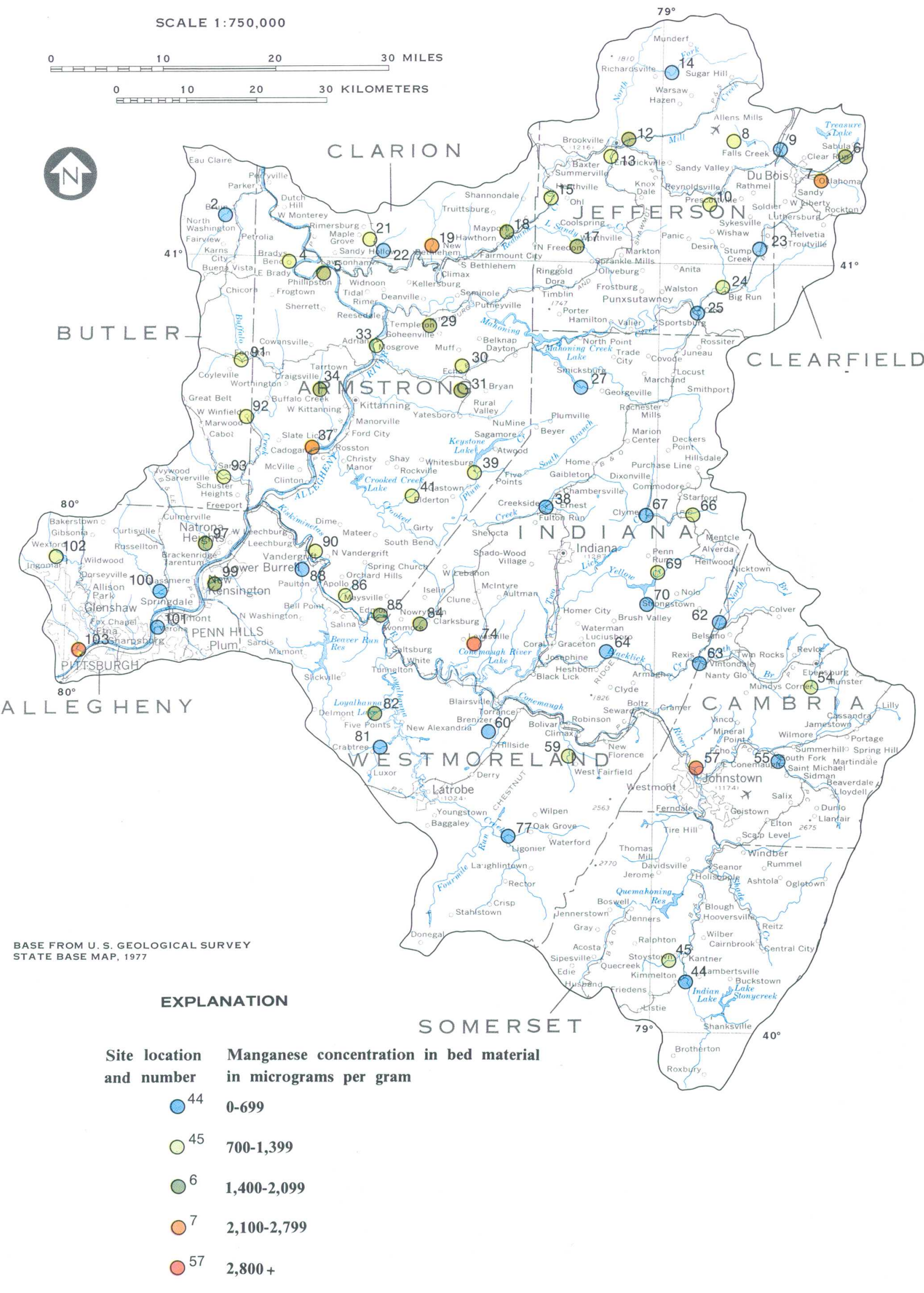

Figure 7.9.1-1 Iron concentrations in bed material for selected streams.

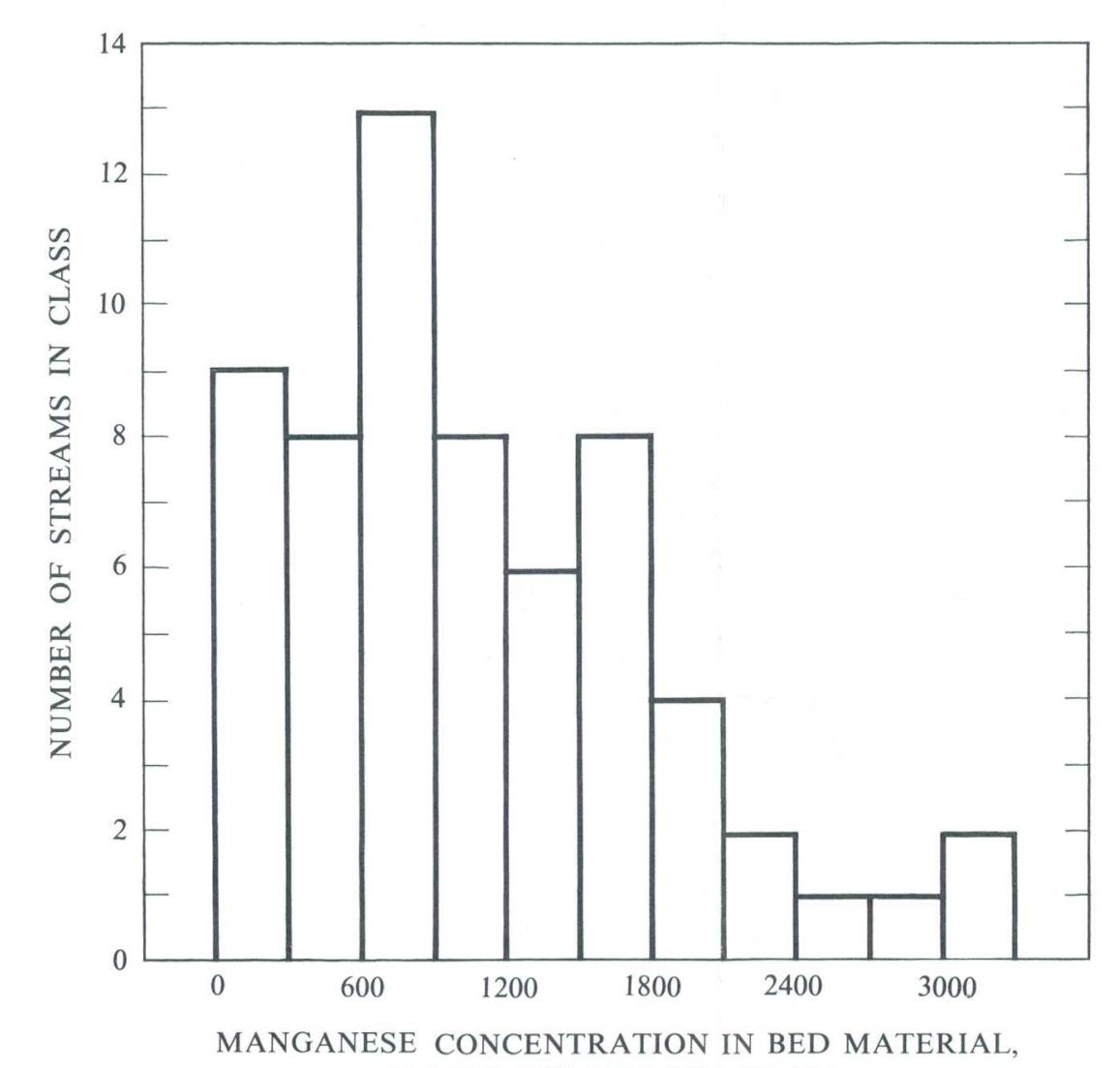

IN MICROGRAMS PER GRAM

Figure 7.9.1-2 Iron concentrations in bed material for selected streams.
7.0 SURFACE-WATER QUALITY (CONTINUED) 7.9 BED MATERIAL 


\title{
7.0 SURFACE-WATER QUALITY (Continued) \\ 7.9 Bed Material (Continued) \\ 7.9.2 Manganese
}

\section{HIGHEST MANGANESE CONCENTRATIONS IN BED MATERIALS ARE SCATTERED OVER AREA}

\author{
The highest manganese concentrations in bed material \\ are widely scattered over Area 3, and are not confined \\ to specific drainage basins. The manganese concentrations \\ ranged from $50 \mu \mathrm{g} / \mathrm{g}$ (micrograms per gram) to $3,300 \mu \mathrm{g} / \mathrm{g}$.
}

Figure 7.9.2-1 illustrates that those streams having the highest manganese concentrations in their bed material are scattered across Eastern Coal Province Area 3 in an almost random fashion. The lowest concentrations tend to occur near the eastern border, but they are not confined to a few drainage basins.

Concentrations of manganese in 62 bed material samples ranged from a low of $50 \mu \mathrm{g} / \mathrm{g}$ to a high of $3,300 \mu \mathrm{g} / \mathrm{g}$. The mean concentration of manganese in bed material was $1,120 \mu \mathrm{g} / \mathrm{g}$ and the median concentration was $920 \mu \mathrm{g} / \mathrm{g}$. Figure 7.9.2-2 shows an almost uniform distribution among concentration classes below 1,500 $\mu \mathrm{g} / \mathrm{g}$ with fewer streams having concentrations in the higher classes. Although 30 streams had iron concentrations in the bed material below $900 \mu \mathrm{g} / \mathrm{g}$, only 10 streams had concentrations greater than $1,800 \mu \mathrm{g} / \mathrm{g}$.

Bed-material samples for manganese determina- tion (Skougstad and others, 1979) were collected at 62 sites during August 1979. Bed materials may serve as historic integrators of basin conditions. As conservative materials pass through the stream channel network they are incorporated into the bed material. Unless extremely high flows scour the bed material and transport it downstream, the deposits may serve as indicators of past water-quality conditions. Feltz (1980) states that concentrations of heavy metals found in bottom materials confirmed potential contamination in the Schuylkill River even though concentrations in the water itself indicated no apparent problem. The concentrations of heavy metals in the bottom materials were several orders of magnitude higher than the concentrations in the water.

Data from the analyses of bed-material samples are published by the U.S. Geological Survey (1980, 1981). 


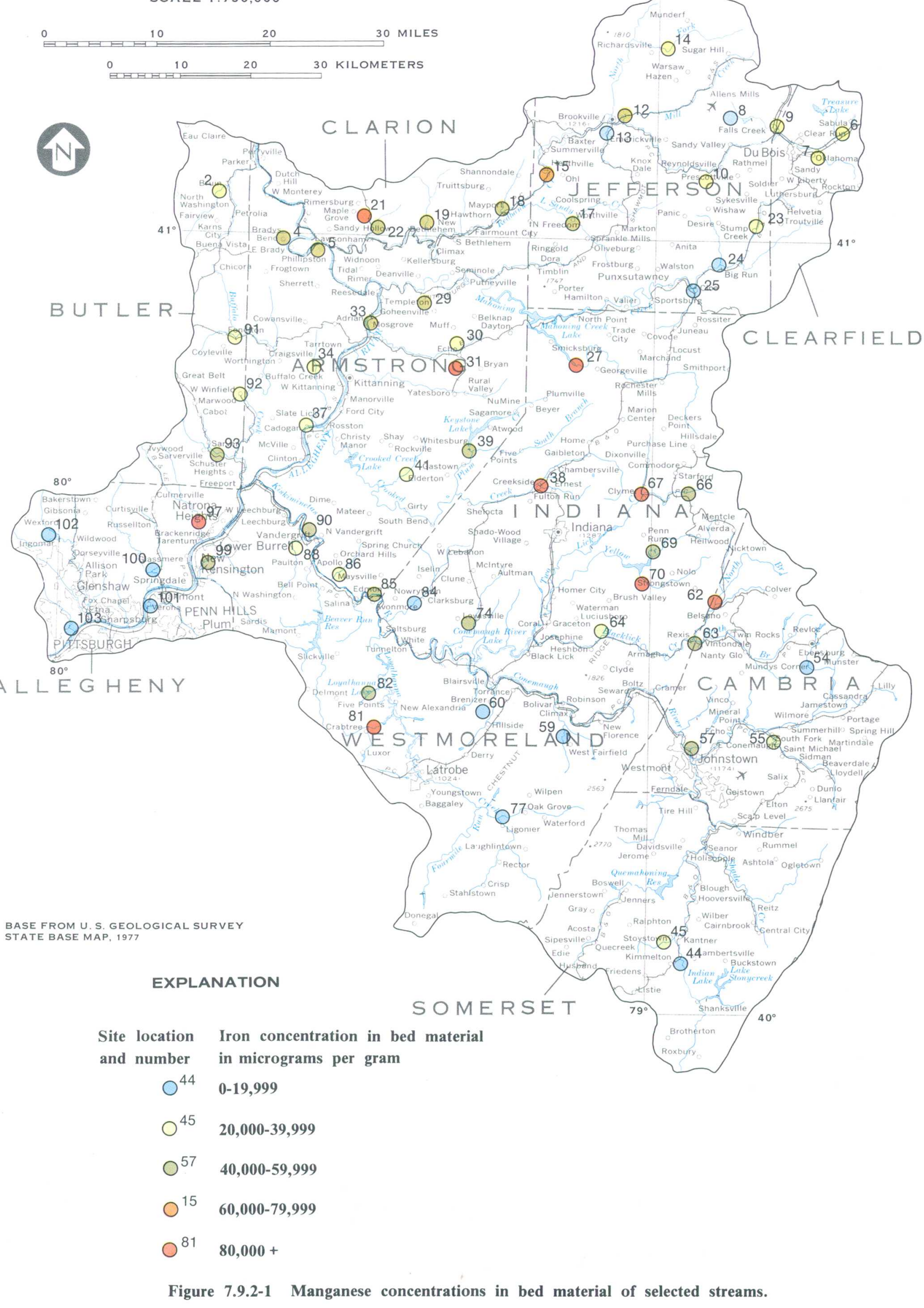

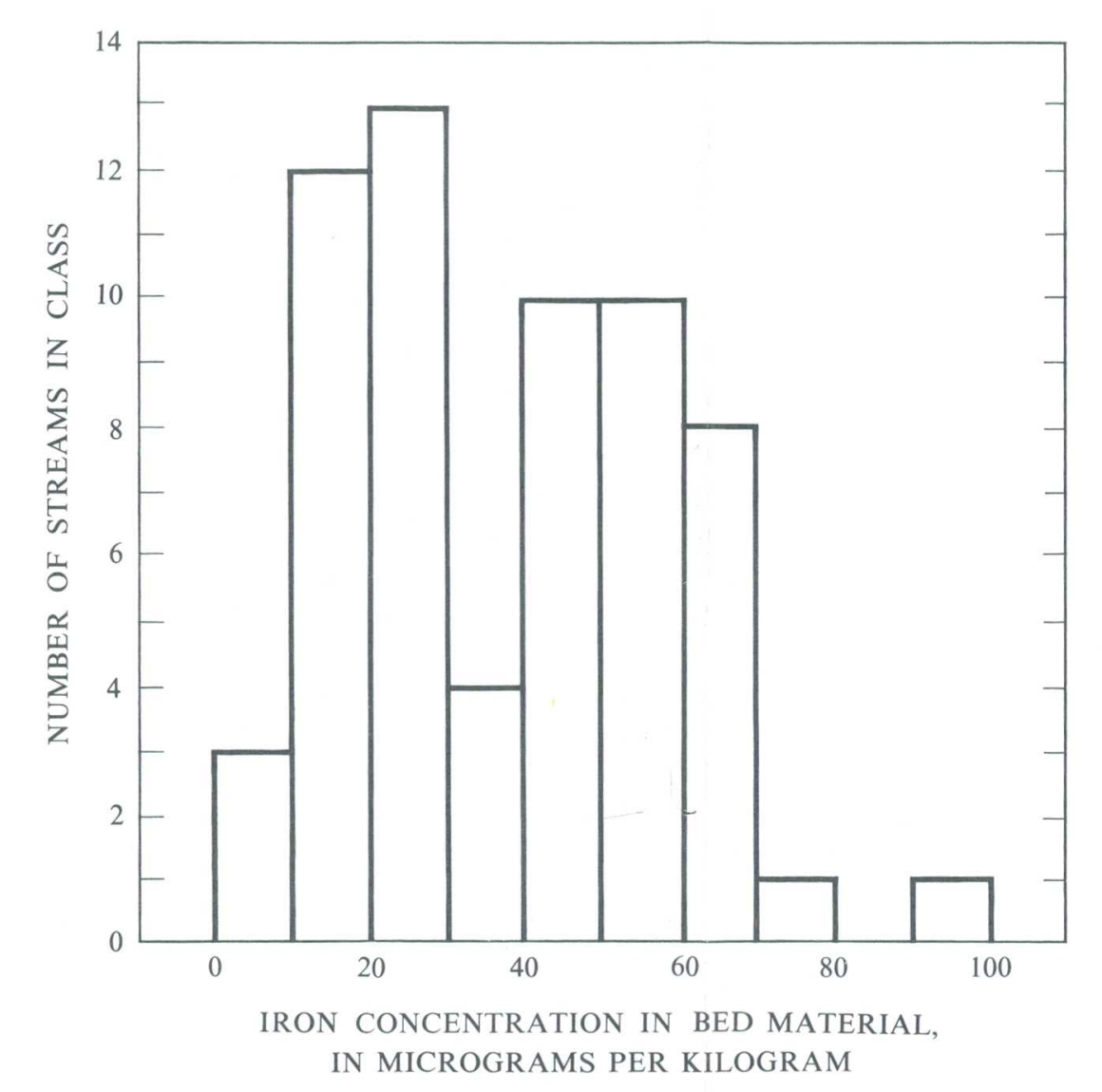

Figure 7.9.2-2 Manganese concentrations in bed material of selected streams.
7.0 SURFACE-WATER QUALITY (CONTINUED) 7.9 BED MATERIAL 7.9.2 MANGANESE 
7.0 SURFACE-WATER QUALITY (Continued)

7.10 Benthic Invertebrates

\section{ELEVEN OF 64 STREAMS SAMPLED IN AREA \\ CONTAINED NO BENTHIC INVERTEBRATES}

No benthic invertebrates were found in 11 of 64 streams sampled

in Area 3. An additional 13 sites had a diversity index

less than 1.0, indicating poor water quality.

Benthic invertebrates were collected by spending 15 minutes sampling all habitats in a stream reach during August 1979. Each habitat's sampling technique varied, but it basically consisted of disturbing ied sarif isms to drift into a mesh net. Contents of the ne ter, and placed into a white polymer tray where specimens were separated and collected into an appropriately labeled jar containing 70-percent alcohol. Taxonomic identification was done in the laboratory.

Benthic invertebrates can be used as indicators of water quality because of their sensitivity to contamican concentrate these contaminans in warer benthic invertebrates or their food sources to die. High flow generally dilutes contaminants unless there is runoff from a mining area during a storm whereby Area 3 generally had intermediate flow in Augus 1979 when benthic invertebrates were collected.

Figure 7.10-1 illustrates the distribution of benthic invertebrate diversity indices computed for 64 streams in Area 3. The Shannon-Weaver diversity (Wilhm and Dorris, 1968) of benthic invert krates sampled in a stream without regard to sample size (Doyle 1979, written communication). A high DI is generally an indicator of good water quality and a low DI is generally an indicator of poor water qual-

Composition of benthic invertebrates is also im portant when interpreting DI values. Ephemeroptera (mayflies), Plecoptera (stonefiles), and Trichoptera (caddis flies) are generally found in a healthy stream, whereas Diptera (nies, midges) and snails are commonly found in an unhealthy stream.

Eleven of the 64 streams sampled in August 1979 in Area 3 yielded no benthic invertebrates. An additional five streams did not contain a biological community as defined by The Office of Surface Mining (1979). Its definition of a biological community re-
quires at least two species in either of the phylum Arthropoda (insects, crustaceans, arachnids) or Mollusca (snails, bivalves) to be present. There were 24
streams with diversity indices less than 1.0 or no benthic invertebrates, both indicators of poor water quality. Area 3 streams were found to contain representatives from three phylums; Arthropoda, Mollusca, and Annelida. Eight Arthropod orders and 20 three molluscal orders and families, and on while known order in the phylum Annelida were found.

The most common taxonomic order found in Area 3 was Ephemeroptera (mayflies). Followin Ephemeroptera in abundance, but varying in ran Plecoptera (stoneflies), and Diptera (flies, midges).

Low diversity indices were more common in the southern part of Area 3 than in the northern paat (fig. 7.10-1). Forty-seven percent of the sites in the southern portion of the area had no benthic inverte23 percent of the strems in the northern part were in this category. The Kiskiminetas River basin was the largest in the southern sector and 14 of its 32 streams had no invertebrates or diversity indices less than 1.0. The Redbank Creek basin was the largest in the ams had no invertebrates or diversity indices less than 1.0 .

Though the biological data collected for the southern half of Area 3 showed signs of poor water quality when using only DI as the criteria, the composition of the benthic invertebrates indicated a combination of healthy and unhealthy factors.

In the northern streams the diversity indices in dicated a healthier environment than in the southern portion, but the composition of benthic invertebrates tions were present in the streams.

Identification of benthic invertebrates to the amily or even genus level may be insulficient to adegenus may be intolerant to low $\mathrm{pH}$ or high dissolved sulfate, whereas a different species within the same genus may exhibit entirely different tolerance characteristics.

Table 7.10-1 includes dissolved-sulfate concentrations and associated diversity index values. statistical test indicates that the mean of the sulfate concentrations associated with diversity indices less than 1.0 is higher than the mean of the sulfate value
associated with diversity indices greater than 1.0. A high diversity index for benthic invertebrates this study, a diversity index greater than 2.5 would denote a healthy environment with a large variety of taxonomic orders and no one order dominating with its population (Craig Moore, oral communication, than or equal to 2.5. Evidence of poorer water qualor very small populations within each. The benthic invertebrate communities at the majority of the sites in Area 3 were indicative of relatively poor water quality, having diversity index values greater than or equal to 1.0 but less than 2.0. Most of these sites had high total-iron or dissolved-sulfate concentrations and benthic-invertebrate compositions hdicating water quality would be represented by the 16 sites lacking a biological community as defined by OSM (see table 7.10-1). These sites generally had the highest ranges for total iron, dissolved sulf ate, and specific conductance, and the lowest range for $\mathrm{pH}$. 


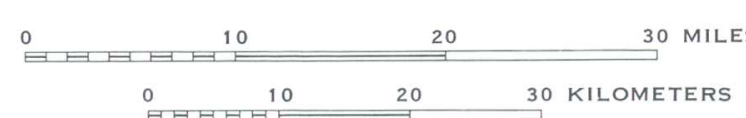

(1)

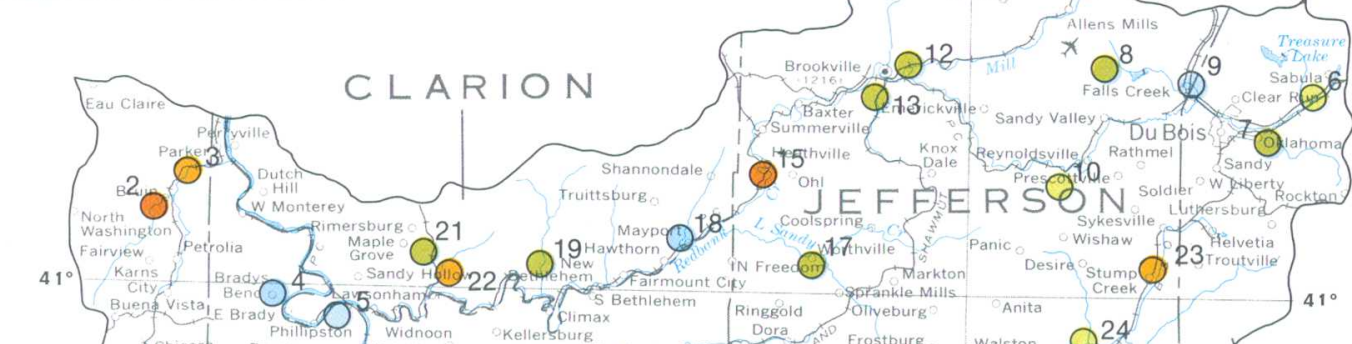

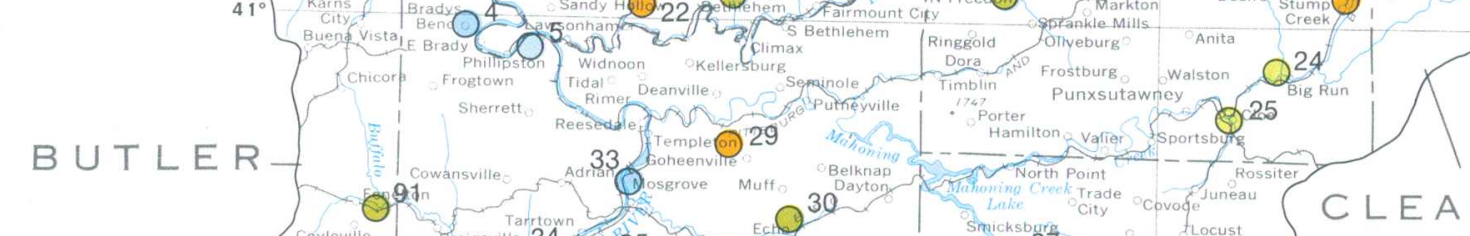

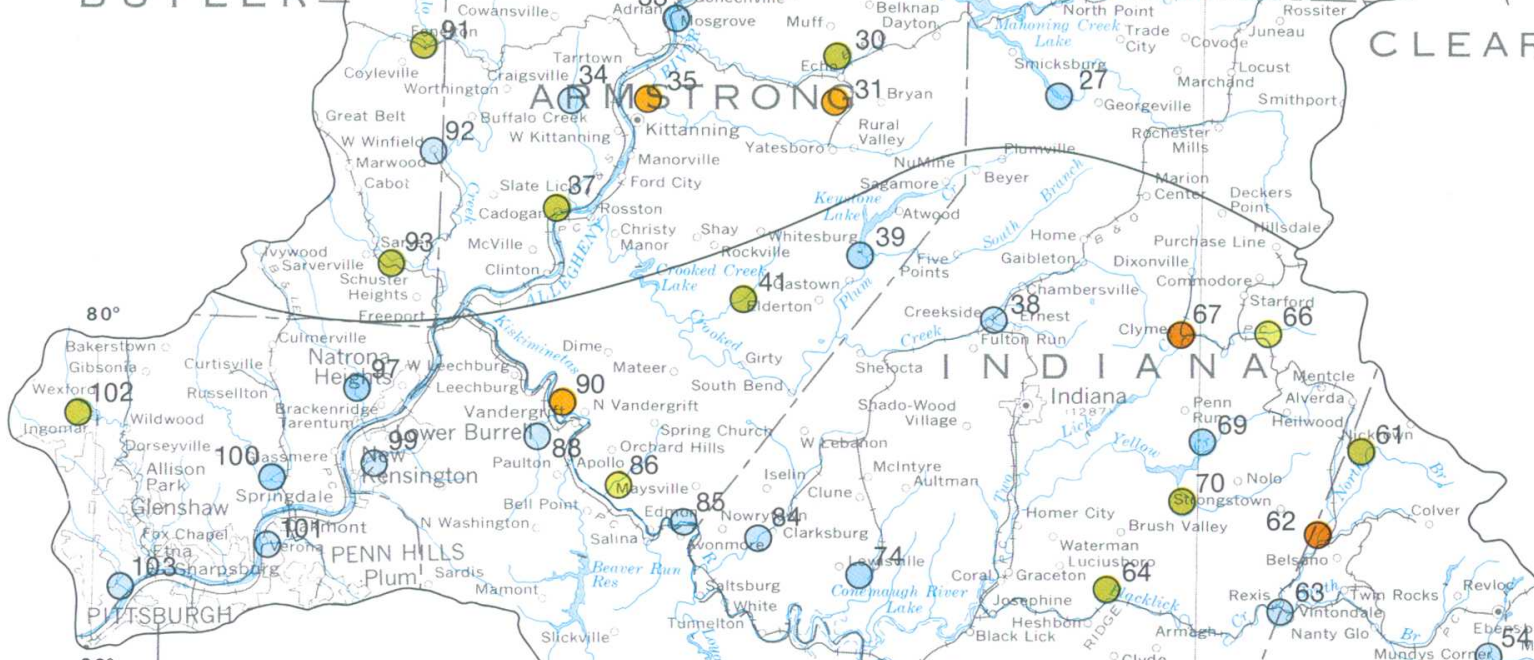

$A L L \stackrel{80^{\circ}}{E} G H E N Y$

BASE FROM U. S. GEOLOGICAL SURVEY
STATE BASE MAP, 1977

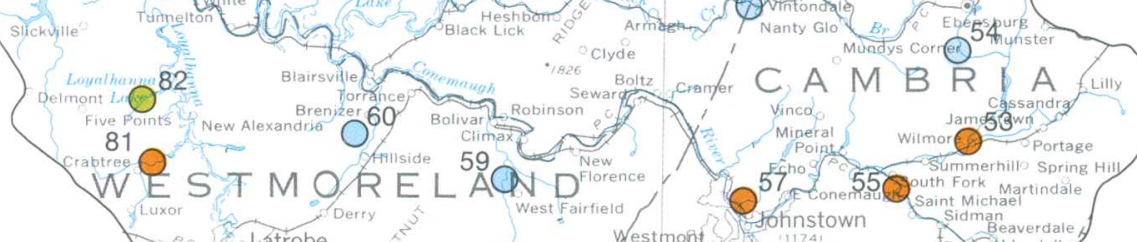

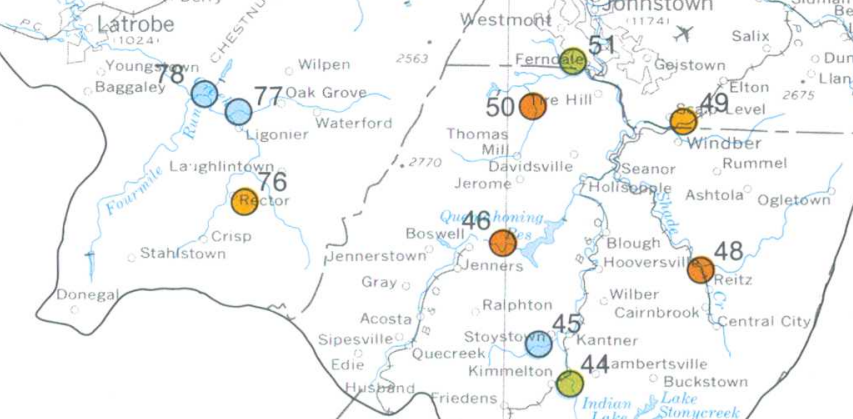

EXPLANATION

$$
\text { SOMERSET }
$$

Site location Shannon-Weaver diversity index

and number

$$
\begin{array}{llll}
\bigcirc^{48} & 0.0-99 & & \\
\bigcirc^{45} & 1.0-1.49 & \bigcirc^{49} & \text { No Sample } \\
\bigcirc^{6} & 1.5-1.99 & \bigcirc^{48} & \text { No invertebrates found } \\
\bigcirc^{51} & 2.0-2.49 & -\quad \begin{array}{l}
\text { Division between north and } \\
\text { south portions of Area 3 }
\end{array}
\end{array}
$$

\begin{tabular}{|c|c|c|c|c|c|c|c|c|}
\hline \multirow{2}{*}{$\begin{array}{c}\text { Site } \\
\text { Number }\end{array}$} & \multicolumn{2}{|r|}{ Station } & \multirow{2}{*}{$\begin{array}{c}\mathrm{pH} \\
\text { (units) }\end{array}$} & \multirow{2}{*}{$\begin{array}{l}\text { Dissolved sulfate } \\
(\mathrm{mg} / \mathrm{L})\end{array}$} & \multirow{2}{*}{$\begin{array}{l}\text { Total iron } \\
(\mu \mathrm{g} / \mathrm{L})\end{array}$} & \multirow{2}{*}{$\begin{array}{c}\begin{array}{c}\text { Conductivity } \\
\text { (mhos) }\end{array} \\
\end{array}$} & \multirow{2}{*}{$\begin{array}{c}\text { Diversity } \\
\text { index }\end{array}$} & \multirow{2}{*}{$\begin{array}{l}\text { Number } \\
\text { of orders }\end{array}$} \\
\hline & $\begin{array}{ll}\text { Number } \\
\end{array}$ & 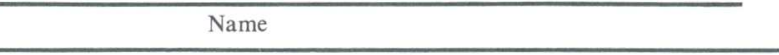 & & & & & & \\
\hline 2 & 03031508 & South Branch Bear Creek at Bruin, Pa. & 7.3 & $1.9 \mathrm{k}$ & $12 \mathrm{k}$ & $6.6 \mathrm{k}$ & $\overline{-}$ & -- \\
\hline${ }_{4}^{3}$ & 31510 & $\begin{array}{l}\text { North Branch Bear } \\
\text { Sugar Creek at East }\end{array}$ & $7^{*} 3$ & $190^{*}$ & $230^{*}$ & . & 3.3 & * \\
\hline $\begin{array}{l}4 \\
5\end{array}$ & 03031550 & $\begin{array}{l}\text { Hugar creek at East Brady, Pa. } \\
\text { Haling Run at Van Buren, Pa. }\end{array}$ & $\begin{array}{l}1.3 \\
5.4\end{array}$ & ${ }_{210}^{190}$ & ${ }^{230} 1 \mathrm{k}$ & 462 & ${ }_{0}^{1.3}$ & ${ }_{1}^{4}$ \\
\hline 6 & 031605 & Narrows Creek near Sabula, Pa. & $\begin{array}{l}3.4 \\
6.3\end{array}$ & 45 & $560^{16}$ & 200 & 2.4 & $\frac{1}{6}$ \\
\hline 7 & 031620 & Laborde Branch near Homecamp, Pa. & 6.1 & 79 & $1.1 \mathrm{k}$ & 280 & 1.7 & 4 \\
\hline $\begin{array}{l}8 \\
9\end{array}$ & 316502 & $\begin{array}{l}\text { Kyle Run near Fal1s Creek, Pa. } \\
\text { Wolf Run at Falls Creek, Pa. }\end{array}$ & $\begin{array}{l}6.6 \\
6.4\end{array}$ & $\begin{array}{l}25 \\
39\end{array}$ & $\begin{array}{l}1.1 \mathrm{k} \\
2.1 \mathrm{k}\end{array}$ & 128 & 1.6 & 4 \\
\hline & 31720 & Trout Run near Reynoldsville, Pa. & $\begin{array}{l}0.4 \\
6.5\end{array}$ & 36 & $\begin{array}{l}2.1 \mathrm{k} \\
2.6 \mathrm{k}\end{array}$ & 200 & 2.0 & ${ }_{5}^{1}$ \\
\hline 12 & 31870 & Mill Creek at Brookville, Pa. & 7.0 & 36 & 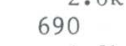 & 200 & $\begin{array}{l}2.0 \\
1.6\end{array}$ & 4 \\
\hline 13 & 031871 & $\begin{array}{l}\text { Five Mile Run at Brookvilie, Pa. } \\
\text { North Fork near Blowtown Pa. }\end{array}$ & 6.6 & 40 & 1.2 & 128 & 1.8 & 4 \\
\hline${ }_{15}^{14}$ & 31873 & $\begin{array}{l}\text { North Fork near Blowtown, Pa. } \\
\text { Beaver Run at Heathville, Pa. }\end{array}$ & 6.7 & 9.1 & 610 & 60 & 1.7 & 4 \\
\hline 15 & 31951 & $\begin{array}{l}\text { Beaver Run at Heathville, Pa. } \\
\text { Big Run near Sprankle Mills, Pa. }\end{array}$ & $\begin{array}{l}4.1 \\
6.8\end{array}$ & $\begin{array}{l}290 \\
57\end{array}$ & $\begin{array}{l}2.3 \mathrm{k} \\
2.1 \mathrm{k}\end{array}$ & $\begin{array}{l}640 \\
228\end{array}$ & 1.5 & $-\frac{-}{6}$ \\
\hline 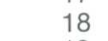 & 32025 & $\begin{array}{l}\text { Pine Creek at Mayport, Pa. } \\
\text { Pad }\end{array}$ & 7.0 & 150 & $12 \mathrm{k}$ & 440 & 1.0 & $\begin{array}{l}6 \\
3\end{array}$ \\
\hline$?$ & 32400 & $\begin{array}{l}\text { Leatherwood Creek near New Bethlehem, Pa. } \\
\text { wildcat Run at Diamond, Pa. }\end{array}$ & $\begin{array}{l}7.0 \\
3.9\end{array}$ & 390 & 560 & 770 & 1.7 & 4 \\
\hline $\begin{array}{l}21 \\
22\end{array}$ & $\begin{array}{l}032757 \\
032770\end{array}$ & $\begin{array}{l}\text { Wildcat Run at Diamond, Pa. } \\
\text { Fiddlers Run near Rimersburg, Pa. }\end{array}$ & $\begin{array}{c}3.9 \\
\star\end{array}$ & $\begin{aligned} 510 \\
*\end{aligned}$ & ${ }_{*}^{3 k}$ & $\begin{array}{c}1020 \\
*\end{array}$ & ${ }^{1.8}$ & 5 \\
\hline 23 & 03033218 & Stump Creek near Big Creek, Pa. & * & * & * & * & $*$ & \\
\hline${ }_{25}^{24}$ & 333290 & $\begin{array}{l}\text { Big Run at Big Run, Pa. } \\
\text { Canoe Creek at Cloe, Pa. }\end{array}$ & $\begin{array}{l}6.9 \\
6.8\end{array}$ & $\begin{array}{l}40 \\
89\end{array}$ & 720 & 344 & $\begin{array}{l}2.0 \\
2.1\end{array}$ & $\frac{5}{6}$ \\
\hline 27 & 03034500 & $\begin{array}{l}\text { Litte Mahoning Creek at McCormick, Pa. } \\
\text { s.t. }\end{array}$ & 6.8 & 38 & 1.4 & 239 & 1.3 & 4 \\
\hline & 366220 & $\begin{array}{l}\text { ccrubgrasss Creek at Goshenville, Pa. } \\
\text { North Branch South Fork Pine Creek at E }\end{array}$ & 6.9 & $40^{*}$ & & $\begin{array}{r}* \\
186\end{array}$ & $*$ & * \\
\hline 31 & 36230 & 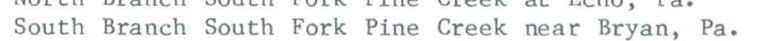 & & & & & $\begin{array}{l}1.6 \\
*\end{array}$ & ${ }_{*}^{4}$ \\
\hline 3 & 36310 & North Fork Pine Creek at Mosgro & 8. & 120 & 520 & 580 & 1.3 & 4 \\
\hline 34 & 36320 & Limestone Run at Tarrtown, Pa. & 7.2 & 420 & 33 & 900 & & \\
\hline 37 & 30366000 & $\begin{array}{l}\text { Cowanshannock Creek near Sunnyside, Pa. } \\
\text { Glade Run at Cadogan, Pa. }\end{array}$ & 7.1 & $250^{*}$ & $\stackrel{*}{*}$ & $710^{*}$ & $\begin{array}{c}* \\
1.5\end{array}$ & 4 \\
\hline 38 & 036995 & Crooked Creek above McKee Run at Creeksid & 6.6 & 120 & 930 & 440 & .5 & 2 \\
\hline $\begin{array}{l}39 \\
41\end{array}$ & 38100 & $\begin{array}{l}\text { outh Branch Plum Creek near Gastown, Pa. } \\
\text { Cherry Run near Brick Churech, Pa. }\end{array}$ & $\begin{array}{l}6.9 \\
7.8\end{array}$ & $\begin{array}{r}32 \\
330\end{array}$ & $850^{1.1 \mathrm{k}}$ & $\begin{array}{r}200 \\
940\end{array}$ & 1.1 & 6 \\
\hline & 39300 & $\begin{array}{l}\text { herry Run near Brick Curch, Pa. } \\
\text { Wells Creek at Mostoller, Pa. }\end{array}$ & $\begin{array}{l}1.8 \\
5.1\end{array}$ & $\begin{array}{l}330 \\
150\end{array}$ & 要30 & $\begin{array}{l}940 \\
449\end{array}$ & 1.16 & $\begin{array}{c}4 \\
3\end{array}$ \\
\hline 4 & 0 & Beaverdam Creek at Stoyst & 7.6 & 62 & ${ }_{930}^{930}$ & 330 & 1.2 & 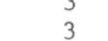 \\
\hline 4 & 039440 & Quemahoning Creek at Boswe11, Pa. & 6.1 & 44 & $1.5 \mathrm{k}$ & 149 & & -- \\
\hline 46 & 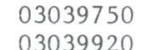 & $\begin{array}{l}\text { Dark Shade Creek at Reitz, Pa. } \\
\text { Lititte paint Greek at scaln }\end{array}$ & 3.3 & 78 & 520 & $\begin{array}{r}810 \\
*\end{array}$ & -1 & -- \\
\hline & 03039950 & $\begin{array}{l}\text { Little paint Creek at Scalp Level, } \text { Pa. } \\
\text { South Fork Bens Creek near Ferndale, }\end{array}$ & 6.8 & 190 & ${ }_{2 \mathrm{k}}^{*}$ & $540^{*}$ & -- & _- \\
\hline $\begin{array}{c}51 \\
53\end{array}$ & $\begin{array}{l}03039957 \\
03040100\end{array}$ & $\begin{array}{l}\text { Bens Creek at Ferndale, Pa. } \\
\text { Little Conemaugh River at Wilmore, Pa. }\end{array}$ & 7.22 & $\begin{array}{r}84 \\
190\end{array}$ & $1.9 \mathrm{k}$ & 119 & 1. & 3 \\
\hline 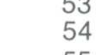 & 40110 & 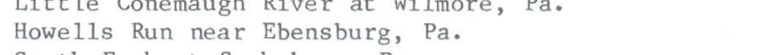 & 7.5 & $\begin{array}{r}190 \\
32\end{array}$ & $570.1 \mathrm{k}$ & $\begin{array}{l}400 \\
460\end{array}$ & 0 & 1 \\
\hline 5 & 03041008 & $\begin{array}{l}\text { South Fork } \\
\text { Hinckston }\end{array}$ & 3.9 & 420 & $31 \mathrm{k}, 2-1-1$ & 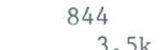 & - & -- \\
\hline $\begin{array}{l}57 \\
59\end{array}$ & $\begin{array}{l}030411008 \\
03041650\end{array}$ & $\begin{array}{l}\text { Hinckston Run at Minersville, Pa. } \\
\text { Hendricks Creek near West Fairfield, Pa. }\end{array}$ & $\begin{array}{l}5.6 \\
7.7\end{array}$ & $65^{1.3}$ & $\begin{array}{l}160 \mathrm{k} \\
1.3 \mathrm{k}\end{array}$ & 240 & 1.3 & \\
\hline $\begin{array}{l}60 \\
61\end{array}$ & $\begin{array}{l}030417700 \\
03041710\end{array}$ & $\begin{array}{l}\text { McGee Run at Brenizer, Pa. } \\
\text { Dutch Run near Blue Goose, Pa. }\end{array}$ & $\begin{array}{l}7.5 \\
7.8\end{array}$ & $\begin{array}{r}36 \\
660\end{array}$ & $\begin{array}{l}750 \\
870\end{array}$ & $\begin{array}{r}318 \\
1450\end{array}$ & $\begin{array}{l}1.3 \\
1.5\end{array}$ & $3^{3}$ \\
\hline 62 & 0041720 & $\begin{array}{l}\text { Elk Creek near Belsano, Pa. } \\
\text { Blacklick Creek at Vintondale, Pa. }\end{array}$ & $\begin{array}{r}4.5 \\
3.9\end{array}$ & $\begin{array}{l}720 \\
730\end{array}$ & $\begin{array}{c}7.2 \mathrm{k} \\
20 \mathrm{k}\end{array}$ & $1190.5 \mathrm{k}$ & $-\overline{0}$ & \\
\hline $\begin{array}{l}63 \\
64\end{array}$ & $\begin{array}{l}03041800 \\
03041900\end{array}$ & $\begin{array}{l}\text { B1acklick Creek at Vintondale, Pa. } \\
\text { Brush Creek at Claghorn, Pa. }\end{array}$ & $\begin{array}{l}3.9 \\
6.7\end{array}$ & 42 & 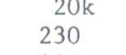 & ${ }_{198}^{190}$ & $\begin{array}{l}0 \\
1.8\end{array}$ & $\frac{1}{5}$ \\
\hline 66 & & $\mathrm{k}$ near w & 6.3 & 22 & 430 & 110 & 2.2 & 7 \\
\hline 67 & 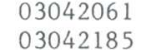 & $\begin{array}{l}\text { Dixon } \\
\text { Yyellow }\end{array}$ & 6.1 & $\begin{array}{r}170 \\
90\end{array}$ & $\begin{array}{c}4.7 \\
300\end{array}$ & $\begin{array}{r}420 \\
388\end{array}$ & - & ${ }_{3}$ \\
\hline 71 & 3042230 & Little Yellow Creek at Suncliff, Pa. & 6.7 & 61 & 80 & 242 & 1.6 & 4 \\
\hline 74 & 90 & $\begin{array}{l}\text { Lewisville, Pa. } \\
\text { at Rector, Pa. }\end{array}$ & $\bar{*}$ & 400 & $\underset{*}{610}$ & - & $\begin{array}{l}1.0 \\
*\end{array}$ & 1 \\
\hline 77 & 4850 & $\begin{array}{l}\text { Loy } \\
\text { Mi1 }\end{array}$ & 8.4 & 130 & 980 & 260 & 4 & 3 \\
\hline 78 & & $\mathrm{Fo}$ & 7.6 & 2 & $9.7 \mathrm{k}$ & 140 & 1.0 & ${ }^{3}>>>>>$ \\
\hline & 03046150 & $\begin{array}{l}\text { rabatree Creek at Crabtree, Pa. } \\
\text { Whitehorn Creek near Shieldsburg, Pa. }\end{array}$ & $\begin{array}{l}6.7 \\
8.0\end{array}$ & $\begin{array}{r}820 \\
73\end{array}$ & $450 \mathrm{k}$ & $\begin{array}{r}1910 \\
455\end{array}$ & 1.8 & 4 \\
\hline $\begin{array}{l}84 \\
85\end{array}$ & 30477807 & g, Pa. & & 430 & 15 & -- & & \\
\hline 86 & 03048200 & Hills, Pa. & 7.7 & 250 & 840 & 650 & 2.2 & 5 \\
\hline $\begin{array}{l}88 \\
90\end{array}$ & & $\begin{array}{l}\text { ultiton, } \\
\text { Vander }\end{array}$ & $\begin{array}{c}5.6 \\
*\end{array}$ & $\begin{array}{l}180 \\
*\end{array}$ & $\begin{array}{r}340 \\
*\end{array}$ & $\begin{array}{l}960 \\
*\end{array}$ & ${ }_{*}^{0}$ & \\
\hline 91 & 8850 & on, Pa. & 7. & 80 & 890 & 400 & 1.6 & \\
\hline 92 & 50 & $\begin{array}{l}\text { Pa. } \\
\text { verville, Pa. }\end{array}$ & 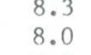 & $\begin{array}{l}49 \\
41\end{array}$ & & & $\begin{array}{l}0 \\
1.7\end{array}$ & \\
\hline 97 & 49610 & rentum, Pa. & 7.9 & 120 & 86 & 582 & 1.1 & 4 \\
\hline 100 & & $\begin{array}{l}\text { Puc } \\
\text { Litit }\end{array}$ & & $\begin{array}{l}110 \\
470\end{array}$ & & $\begin{array}{c}495 \\
1230\end{array}$ & & \\
\hline & & rona, Pa. & 7.6 & 470 & 70 & $1.4 \mathrm{k}$ & $\mathrm{r}$ & \\
\hline 103 & $\begin{array}{l}03049740 \\
03049818\end{array}$ & $\begin{array}{l}\text { Pine Creek near Ingomar, } \\
\text { Girtys Run at Baderstown }\end{array}$ & $8.92-3$ & 130 & $\begin{array}{l}790 \\
300\end{array}$ & 990 & & \\
\hline
\end{tabular}

Figure 7.10-1 Diversity indices at synoptic sites.
Table 7.10-1 Benthic invertebrate and chemical water quality data for streams during August 1979

$*=$ No benthic invertebrate sample taken
$k=$ Take numerical value times 1 topo

7.0 SURFACE-WATER QUALITY (CONTINUED) 7.10 BENTHIC INVERTEBRATES 


\title{
8.0 ACID-MINE DRAINAGE
}

\section{STRONG INDICATIONS OF ACID-MINE DRAINAGE IN 16 STREAMS IN AREA}

\author{
Sixteen streams in Area 3 meet or exceed the \\ levels of $\mathrm{pH}$, acidity-alkalinity, total iron, \\ total manganese, and sulfate which are indicators \\ of acid-mine drainage. Most of the streams are \\ in the Kiskiminetas River basin.
}

A number of water-quality measures have been proposed as indicators of acid-mine drainage (AMD). Five common indicators are (U.S. Department of the Interior, 1968):

$$
\begin{aligned}
& \mathrm{pH}<6.0 \\
& \text { acidity }>\text { alkalinity } \\
& \text { total iron }>0.5 \mathrm{mg} / \mathrm{L} \text { (milligrams per liter) } \\
& \text { total manganese }>0.5 \mathrm{mg} / \mathrm{L} \\
& \text { sulfate }>75 \mathrm{mg} / \mathrm{L}
\end{aligned}
$$

Sixteen of the 73 streams in Eastern Coal Province Area 3 that were sampled during June 1979 to April 1980 met or exceeded all five indicator levels. All indicator levels may not have been met or exceeded during a single sampling, but they were met or exceeded when all samples were considered. Each stream generally had one sample collected during high base flow and two collected during intermediate base flow.

Figure 8.0.1-1 shows the geographic distribution of the stream sites meeting all five AMD criteria. Twelve of the 16 streams meeting all 5 AMD criteria are in the Kiskiminetas River basin. These include 6 of the 11 streams sampled in the upper Conemaugh River basin and 2 of 4 streams sampled in the Blacklick Creek basin. In addition to those streams found in the Kiskiminetas River basin, two streams having all five indicators were found in the Redbank Creek basin, and two more were found tributary to the Allegheny River east of Butler.

The most obvious effect of AMD on a stream may be aesthetic. If the AMD is partially neutralized, as upon contact with unaffected water, dissolved iron in the AMD begins to precipitate in the form of ferric hydroxide. These ferric hydroxides form the orange coatings on stream beds which are commonly associated with AMD, and when in suspension, can give the water a reddish appearance.

Other effects of AMD may not be as noticeable, but may be of greater consequence than the aesthetic considerations. These effects may alter the ability of a stream to support aquatic life, or may adversely affect the quality of the stream's water for a specific use.

Table 8.0-1 presents some of the effects of $\mathrm{pH}$ on aquatic life (International Joint Commission, 1979). Below a $\mathrm{pH}$ of about 6.0, damage begins to occur to aquatic life. The first effect is generally a reduction in the number of species. Among the species still remaining, there may be a deterioration in their abilities to withstand additional forms of stress. As pH decreases below 5.5, many $\mathrm{pH}$ intolerant species will be eliminated. Air breathing invertebrates, tolerant of low $\mathrm{pH}$, may increase in numbers. In spite of the increasing numbers of low-pH tolerant species, the total invertebrate biomass will be greatly reduced. When pH drops below 5.0, most fish species are eliminated. Because the decomposition of organic matter is greatly reduced, there will be an accumulation of debris. Below a $\mathrm{pH}$ of 4.5 , all fish life is eliminated.

When pyrite (iron sulfide) is exposed to water and oxygen, it oxidizes to form a weak sulfuric acid solution. When the sulfuric acid contacts rock strata in the vicinity of the pyrite, it dissolves most metals including iron, manganese, aluminum, sodium, calcium, magnesium, and probably some trace metals. The formation of the sulfuric acid can take place under natural conditions, but mining accelerates the process by exposing large amounts of pyrite which naturally occur near coal seams. 


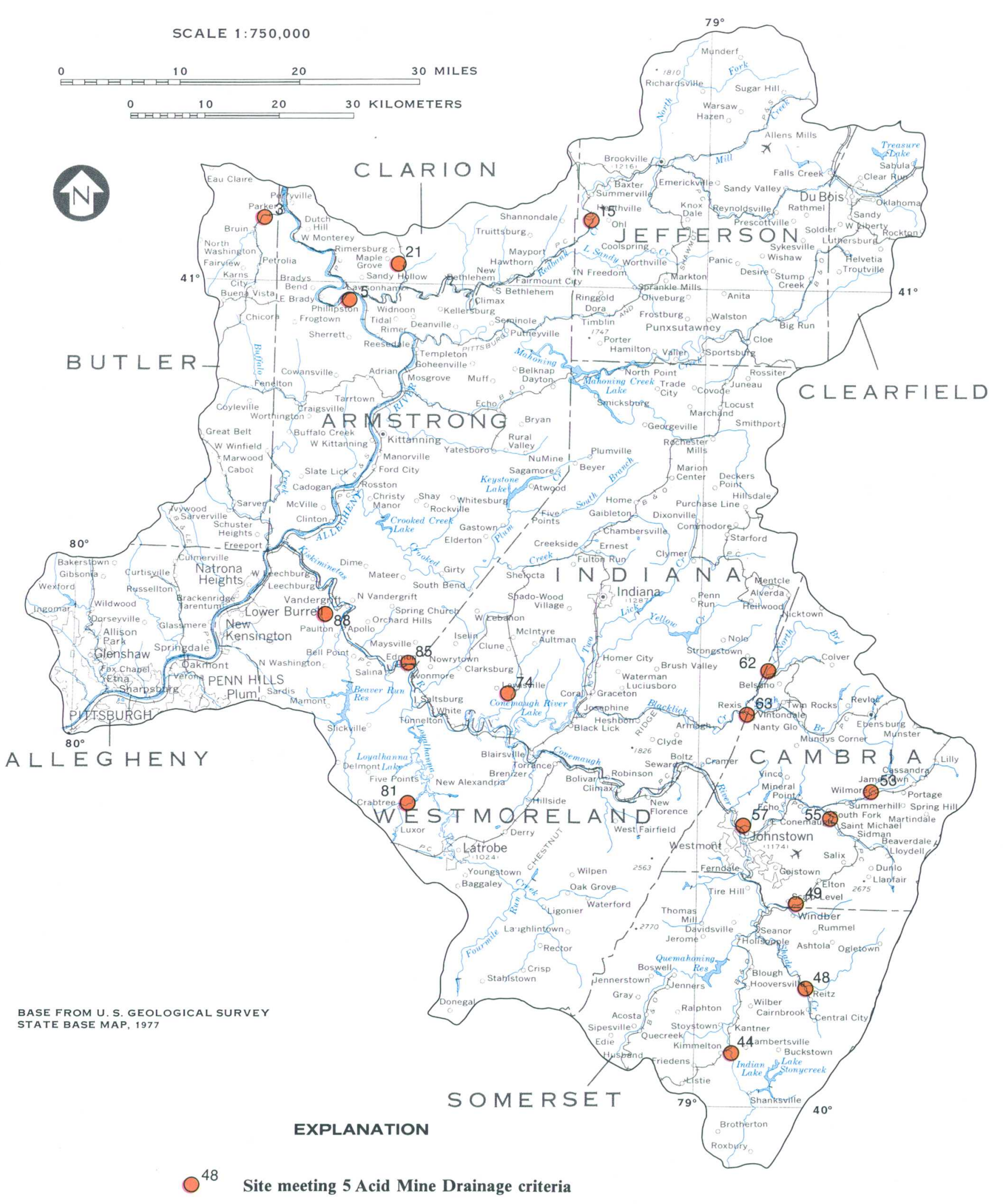

$0^{48} \quad$ Site meeting 5 Acid Mine Drainage criteri
Text continued from $p .50)$

Harvard University (1970) presents the following overall reactions for the mine-water system:

$\mathrm{FeS}_{2}(\mathrm{~S})+7 / 2 \mathrm{O}_{2}+\mathrm{H}_{2}=\mathrm{Fe}^{+2}+\mathrm{SO}_{4}^{-2}+2 \mathrm{H}^{+}$ $\mathrm{Fe}^{+2}+1 / 4 \mathrm{O}_{2}+\mathrm{H}^{+}=\mathrm{Fe}^{+3}+1 / 2 \mathrm{H}_{2} \mathrm{O}$

$\mathrm{Fe}^{+3}+3 \mathrm{H}_{2} \mathrm{O}=\mathrm{Fe}(\mathrm{OH})_{3}(\mathrm{~S})+3 \mathrm{H}^{+}$

$\mathrm{FeS}_{2}(\mathrm{~S})+14 \mathrm{Fe}^{+3}+8 \mathrm{H}_{2} \mathrm{O}=15 \mathrm{Fe}^{+2}+2 \mathrm{SO}^{-2}+16 \mathrm{H}^{+}(8.0-4)$

In the initial step (8.0-1) pyrite is exposed to water sulfate and releasing acidity into the water. Reaction

8.0-2 illustrates the oxidation of ferrous iron to ferric iron which hydrolyzes to form the insoluble ferric hythe water. Reaction 8.0-4 shows that pyrite itself can reduce ferric iron to ferrous iron accompanied by an additional release of acidity. The ferrous iron formed in the step can reenter the reaction cycle as shown in reaction 8.0-2. In waters having low pH the

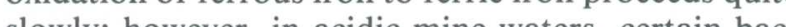
teria are thought to speed the reaction through bacterial catalysis (Harvard University, 1970).

Table 8.0-1 Effects of pH on aquatic life, (International Joint Commission, 1976)

\begin{tabular}{ll}
\hline $\mathrm{pH}$ & \multicolumn{1}{c}{ Effect } \\
\hline 5.5 & $\begin{array}{l}\text { Reduction in species numbers and among remaining } \\
\text { species, alterations in ability to withstand stress. }\end{array}$ \\
5.5 & $\begin{array}{l}\text { Elimination of many species such as mayflies, } \\
\text { stoneflies, and mo1luscs. Air-breathing pH tolerant } \\
\text { invertebrates may become abundant. Greatly reduced } \\
\text { invertebrate biomass. }\end{array}$ \\
5.0 & $\begin{array}{l}\text { Most fish species eliminated. Decomposition of organic } \\
\text { detritus will be impaired and debris will accumulate. }\end{array}$ \\
4.0 & All fish eliminated. \\
\hline
\end{tabular}

Figure 8.0-1 Location of stations meeting $\mathrm{pH}$, alkalinity-acidity, iron, manganese, and sulfate criteria for acid-mine drainage. 


\title{
9.0 SURFACE-WATER QUANTITY \\ 9.1 Daily Discharge
}

\section{DAILY DISCHARGE IS BASIC HYDROLOGIC DATA}

\begin{abstract}
Daily discharge is the average flow rate during each day. It is used in the computation of many hydrologic indices.
\end{abstract}

Mean daily discharge is the rate of flow, if it were constant throughout the day, that would have produced the volume of flow occurring for the day. The basic reporting unit of streamflow is mean daily discharge in cubic feet per second (table 9.1-1).

Daily discharge is computed from a record of stream stage. Stage data are generally recorded at intervals ranging from 5 minutes to 1 hour, but the interval may be longer. Figure 9.1-1 illustrates the variation in stage which occurred during a single day at site 20. Figure 9.1-2 is a discharge hydrograph for the same day at the same station. The discharge hydrograph was computed using the data from the stage hydrograph and the appropriate stage-discharge relation. Although the mean discharge for the illustrated day is $12,100 \mathrm{ft}^{3} / \mathrm{s}$ (cubic feet per second), the actual computed instantaneous discharges range from a low of $2,500 \mathrm{ft}^{3} / \mathrm{s}$ to a high of $19,300 \mathrm{ft}^{3} / \mathrm{s}$.

Mean daily discharges during a period can be presented in tabular form, such as table 9.1-1 for site 83 for October 1975 . The daily discharges can also be presented graphically, as shown in figure 9.1-1 for site 20 for the 1976 water year. Mean daily discharge data have greater utility than simply reporting average discharges for individual days. Daily discharge data are used in the computation of a wide variety of hydrologic products including determinations of long-term mean flows, long-term low flows, and flow-duration curves or tables. 


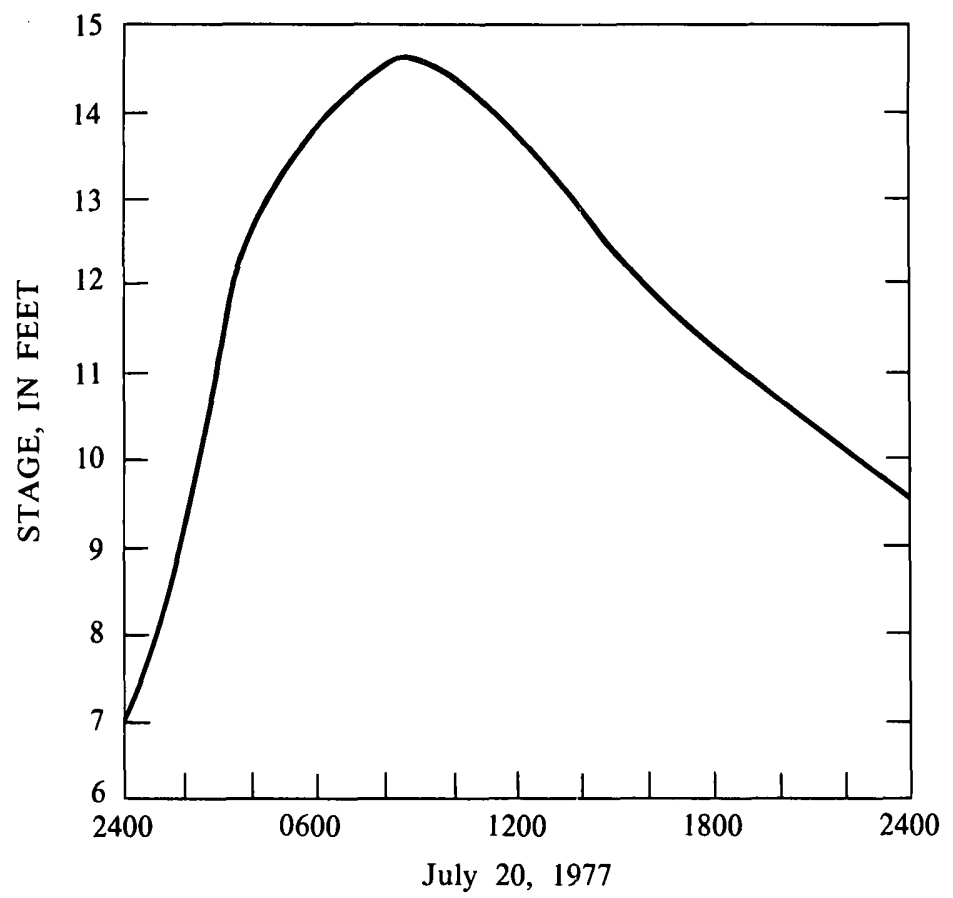

Figure 9.1-1 Stage hydrograph for site number 20 .

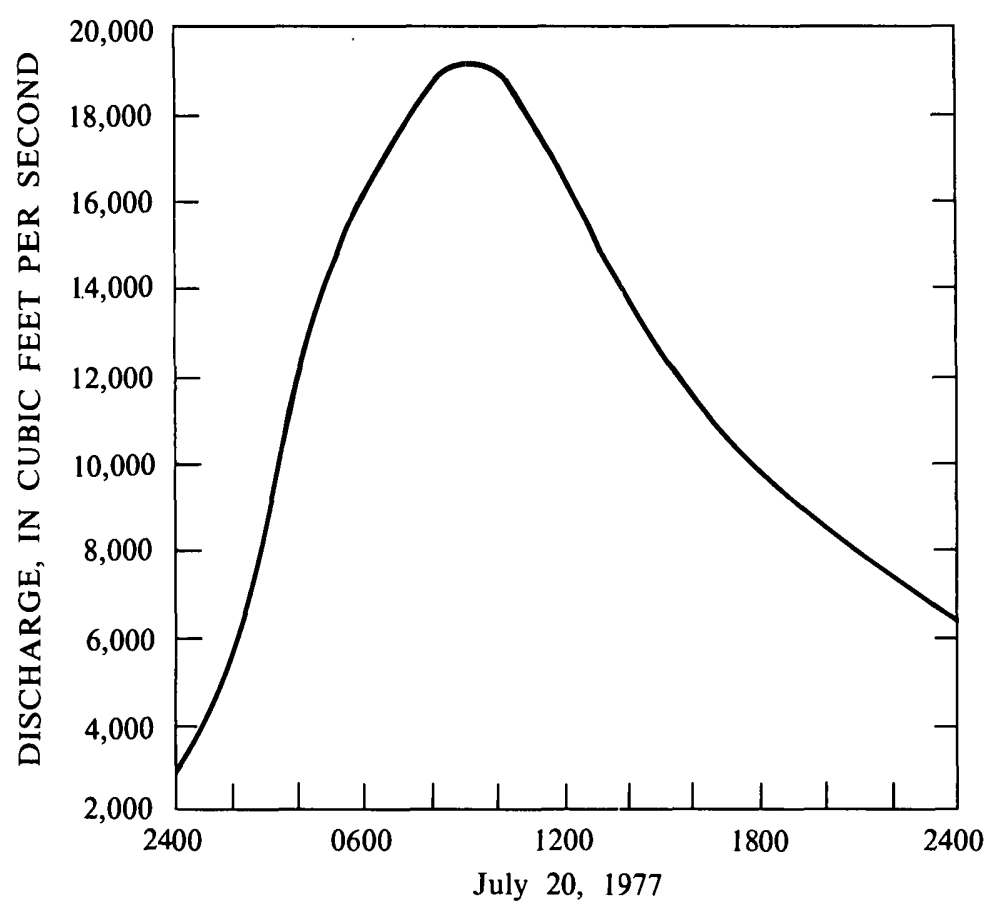

Figure 9.1-2 Discharge hydrograph for site number 20 .

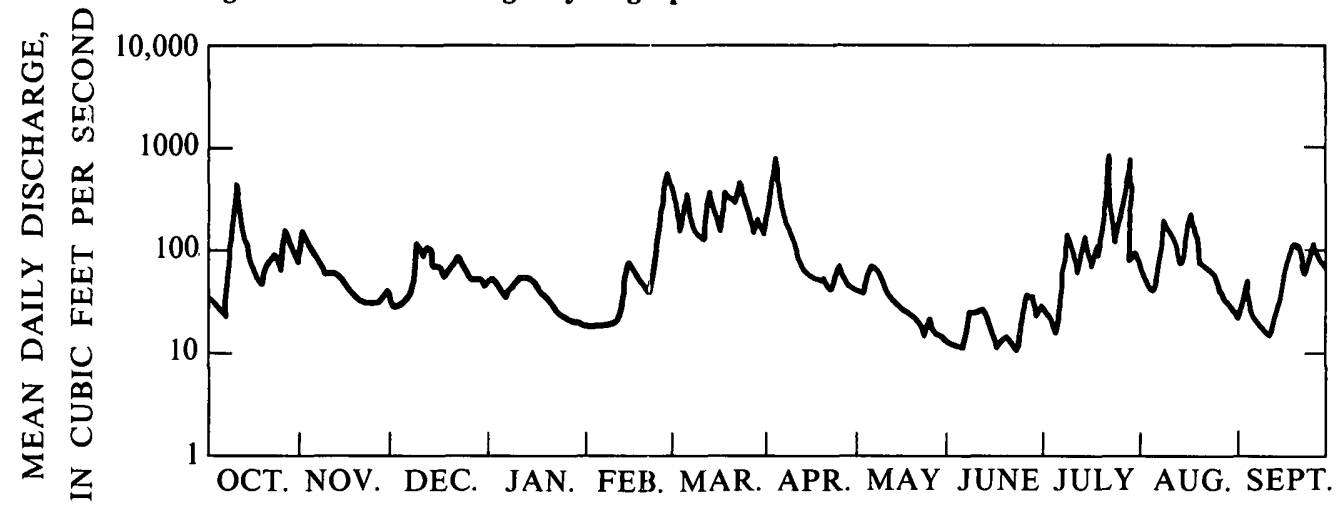

1977 WATER YEAR

Figure 9.1-3 Daily-discharge hydrograph for site number 20 . 


\title{
9.0 SURFACE-WATER QUANTITY (Continued) 9.2 Low Flow 9.2.1 Gaged Sites
}

\section{LOW FLOW STATISTICS ARE AVAILABLE FOR 10 GAGED STREAMS IN AREA}

\author{
Low flow statistics have been computed from recorded daily \\ discharge records for 10 gaging stations in Area 3. These \\ statistics can be useful in determining water supply \\ adequacy during period of low flow.
}

Table 9.2-1 presents low flow statistics for 10 gaging stations in Eastern Coal Province Area 3 that are not significantly affected by low-flow regulation. These statistics are based upon an analysis of daily streamflow data collected at each of the stations. The low flow statistics are presented as the probability that the average flow for a given number of days will not exceed a specified value. For example, examine the row labled 16, under the major column heading of 20 percent and under the 3-day column subheading. The value of $0.47 \mathrm{ft}^{3} / \mathrm{s}$ (cubic feet per second) indicates that at site 16 there is a 20 -percent chance that the average flow for 3 consecutive days will be less than $0.47 \mathrm{ft}^{3} / \mathrm{s}$. Similarly, at site 16 there is a 1-percent chance that the average flow for 120 consecutive days will be less than $0.87 \mathrm{ft}^{3} / \mathrm{s}$.

The statistics presented in table 9.2.1-1 have been computed using all daily discharges collected at a station. The same type of statistics can be computed for an individual month or for a season. Low-flow statistics are useful when determining the probable adequacy of a water supply for such uses as drinking water or as a receiving body for waste discharges. 
Table 9.2.1-1 Average flows, in cubic feet per second, which have the specified probability of not being exceeded in the specified number of consecutive days for gaging station.

Probability of observed value not exceeding the tabular value (percent)

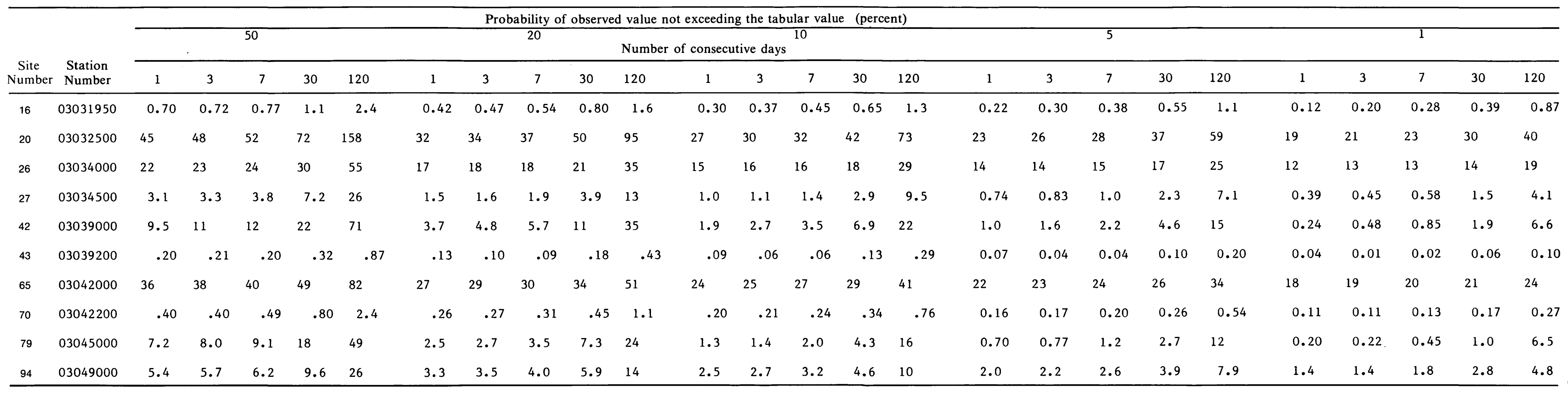

9.0 SURFACE-WATER QUANTITY (CONTINUED) 9.2 LOW FLOW

9.2.1 GAGED SITES 


\title{
9.0 SURFACE-WATER QUANTITY (Continued) \\ 9.2 Low Flow (Continued) \\ 9.2.2 Ungaged Sites
}

\section{LOW FLOW STATISTICS CAN BE ESTIMATED FOR UNGAGED STREAMS}

\author{
Techniques have been developed \\ which permit the estimation of low-flow \\ statistics for ungaged streams in Area 3.
}

Special techniques are required to estimate lowflow statistics for ungaged streams. Such techniques have been developed for streams in Eastern Coal Province Area 3. Flippo (1981) presents regression equations for estimating average minimum discharges for 3-, 7-, 30-, and 120-consecutive-day intervals at nonexceedance probabilities of $20,10,5,2$, and 1 percent. Flippo also presents equations for estimating minimum discharges for $1,3,7$, and 30 days at the same nonexceedance probabilities for each of the 6 months, May through October. Flippo (1981) subdivided the State into a number of low-flow re- gions. Area 3 falls in the three regions designated 10, 11 , and 12.

The independent variables found to be significant in estimating low flows were drainage area, an annual precipitation index, a geologic index, and channel slope. Not all of the independent variables are used in the estimating equations for each region. For the application of the equations the reader is referred to Flippo (1981). 


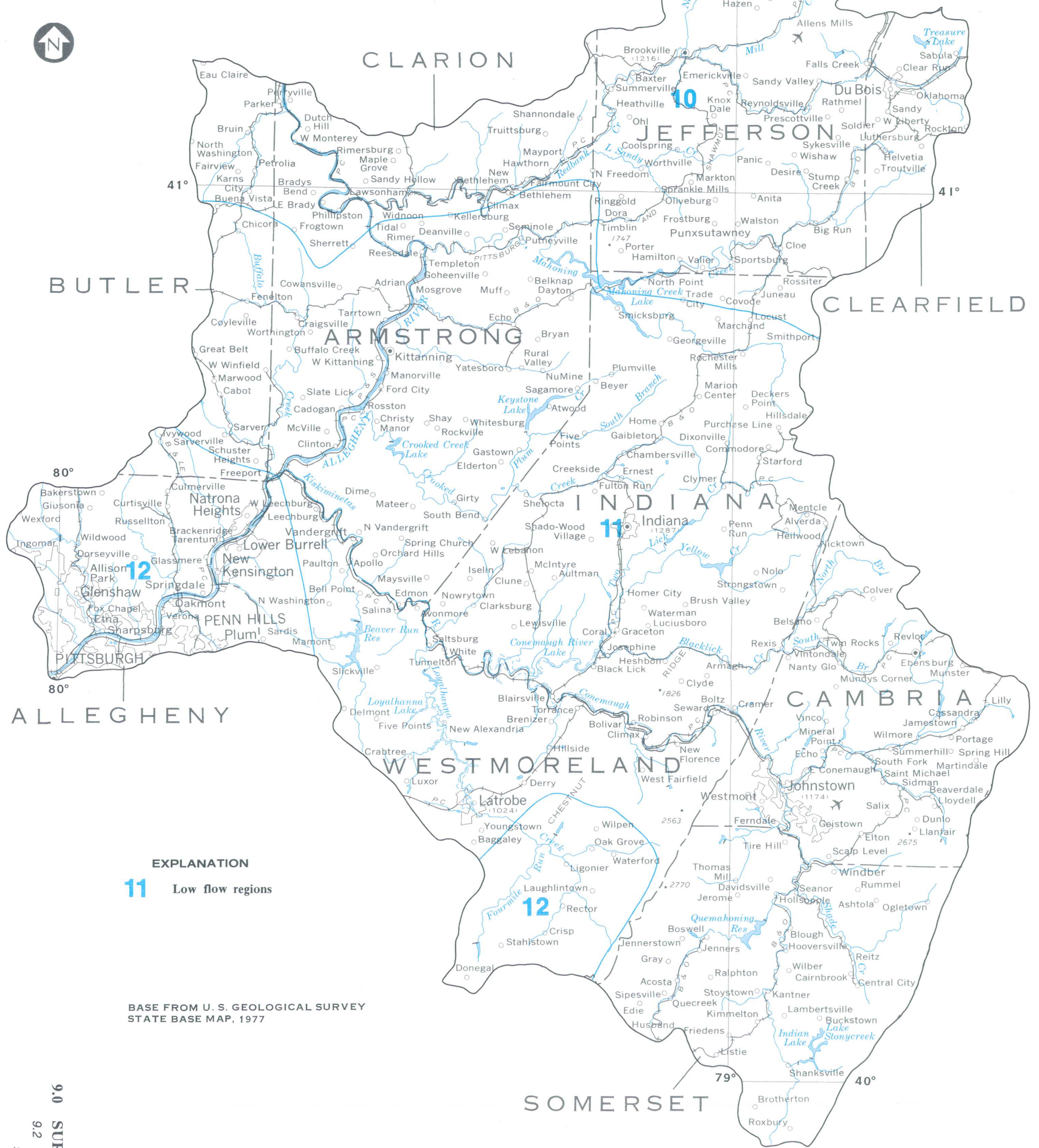

\begin{tabular}{lll}
10 & 20 & 30 \\
\hline
\end{tabular} 


\subsection{SURFACE-WATER QUANTITY (Continued) \\ 9.3 Mean Flow \\ 9.3.1 Gaged Sites}

\section{MEAN FLOW DATA ARE AVAILABLE FOR 23 GAGED SITES}

\section{Mean flow data have been summarized for 23 gaging stations \\ in Area 3. Both regulated and nonregulated streams have been included in the analysis.}

Mean annual and mean monthly flows for 23 gaging stations are summarized in table 9.3.1-1. The values in the table are based upon measured daily discharges through the 1977 water year, and are only estimates of the long-term mean flows which may occur at these stations. If "ANNUAL", in the row labled 1 indicates that the average discharge over the entire period of record for this station is $13,200 \mathrm{ft}^{3} / \mathrm{s}$ (cubic feet per second). Similarly, the column headed "OCTOBER" opposite this station number indi- cates that the average discharge during all Octobers in the period of record is $5,500 \mathrm{ft}^{3} / \mathrm{s}$.

Mean flows are a function of several basin and climatic characteristics. Drainage area, average annual precipitation, average annual potential evapotranspiration, and mean basin elevation have been found to be significant in mean flow determination. More statistical data are given by Herb (1981). 
Table 9.3.1-1 Measured mean discharges at gaging stations.

\begin{tabular}{|c|c|c|c|c|c|c|c|c|c|c|c|c|c|c|}
\hline \multirow{2}{*}{$\begin{array}{c}\text { Site } \\
\text { Number }\end{array}$} & \multirow{2}{*}{$\begin{array}{l}\text { Station } \\
\text { Number }\end{array}$} & \multicolumn{13}{|c|}{ Mean discharge for period indicated (cubic feet per second) } \\
\hline & & Annual & October & November & December & January & February & March & April & May & June & July & August & September \\
\hline 1 & 03031500 & 13,200 & 5,500 & 10,400 & 15,600 & 17,700 & 17,800 & 25,700 & 25,400 & 15,600 & 9,140 & 5,460 & 3,770 & 3,990 \\
\hline 16 & 03031950 & & 6.6 & 12 & 17 & 18 & 20 & 27 & 18 & 13 & 7.6 & 5.0 & 4.6 & 5.8 \\
\hline 20 & 03032500 & 858 & 309 & 612 & 1,023 & 1,240 & 1,270 & 1,870 & 1,520 & 1,048 & 588 & 350 & 255 & 218 \\
\hline 26 & 03034000 & 276 & 108 & 186 & 313 & 360 & 433 & 588 & 473 & 347 & 195 & 129 & 100 & 85 \\
\hline 27 & 03034500 & 152 & 62 & 114 & 188 & 219 & 253 & 320 & 245 & 175 & 92 & 61 & 53 & 46 \\
\hline 28 & 03036000 & 593 & 238 & 397 & 650 & 818 & 908 & 1,300 & 1,030 & 738 & 391 & 274 & 216 & 176 \\
\hline 36 & 03036500 & 15,600 & 7,500 & 12,800 & 17,700 & 21,300 & 20,900 & 34,100 & 27,900 & 18,600 & 10,700 & 6,400 & 4,500 & 4,900 \\
\hline 40 & 03038000 & 288 & 122 & 191 & 347 & 405 & 518 & 611 & 477 & 306 & 195 & 130 & 88 & 86 \\
\hline 42 & 03039000 & 415 & 175 & 319 & 478 & 614 & 688 & 887 & 654 & 443 & 276 & 184 & 142 & 140 \\
\hline 43 & 03039200 & 6.0 & 3.5 & 4.3 & 7.8 & 6.2 & 8.3 & 13 & 12 & 7.5 & 5.3 & 2.1 & 1.3 & 1.4 \\
\hline 52 & 03040000 & 634 & 207 & 314 & 625 & 804 & 979 & 1,570 & 1,320 & 782 & 500 & 218 & 159 & 143 \\
\hline 56 & 03041000 & 298 & 107 & 158 & 301 & 362 & 428 & 703 & 588 & 357 & 256 & 153 & 98 & 77 \\
\hline 58 & 03041500 & 1,270 & 535 & 720 & 1,230 & 1,540 & 1,880 & 2,830 & 2,400 & 1,510 & 1,067 & 636 & 483 & 440 \\
\hline 65 & 03042000 & 365 & 165 & 228 & 405 & 448 & 577 & 791 & 625 & 402 & 250 & 198 & 158 & 141 \\
\hline 70 & 03042200 & 13 & 3.9 & 11 & 17 & 18 & 20 & 31 & 21 & 14 & 9.0 & 3.7 & 3.1 & 5.7 \\
\hline 72 & 03042280 & 107 & 58 & 81 & 148 & 129 & 163 & 189 & 147 & 107 & 92 & 86 & 38 & 47 \\
\hline 73 & 03042500 & 278 & 127 & 179 & 319 & 368 & 457 & 576 & 453 & 318 & 189 & 160 & 102 & 101 \\
\hline 75 & 03044000 & 2,360 & 987 & 1,360 & 2,430 & 3,000 & 3,460 & 5,180 & 4,280 & 2,870 & 1,960 & 1,190 & 898 & 744 \\
\hline 79 & 03045000 & 294 & 95 & 172 & 343 & 422 & 463 & 614 & 532 & 376 & 254 & 99 & 93 & 80 \\
\hline 83 & 03047000 & 479 & 164 & 254 & 514 & 643 & 760 & 1,023 & 846 & 609 & 417 & 208 & 173 & 154 \\
\hline $\begin{array}{l}80 \\
89\end{array}$ & 03048500 & 3,044 & 1,240 & 1,700 & 3,150 & 3,880 & 4,720 & 6,680 & 5,510 & 3,690 & 2,540 & 1,480 & 1,120 & 922 \\
\hline 94 & 03049000 & 190 & 66 & 113 & 225 & 275 & 339 & 427 & 332 & 222 & 128 & 61 & 55 & 45 \\
\hline 96 & 03049500 & 19,200 & 8,060 & 13,900 & 22,000 & 24,800 & 27,600 & 41,400 & 36,700 & 23,300 & 13,900 & 8,200 & 5,740 & 5,710 \\
\hline
\end{tabular}

9.0 SURFACE-WATER QUANTITY (CONTINUED) 9.3 MEAN FLOW

9.3.1 GAGED SITES 


\subsection{SURFACE-WATER QUANTITY (Continued) \\ 9.3 Mean Flow (Continued) \\ 9.3.2 Ungaged Sites}

\section{ESTIMATING MEAN FLOWS AT UNGAGED SITES}

\section{Mean flows can be estimated for sites which have no gage record if certain basin and climatic parameters are known.}

Techniques have recently been developed which allow the estimation of mean flow characteristics at stream sites having no gaging station records. Mean and mean monthly flows can be estimated through the use of a series of regression equations (table 9.3.2-1) developed by Herb (1981). These equations were developed and calibrated with data from many gaged streams in and around Area 3. In order to use these equations, several basin and climatic parameters must be determined. The parameters required are drainage area, mean annual precipitation, potential annual evapotranspiration, and mean basin elevation. These parameters can be determined from topographic maps and the maps presented by Herb (1981). Although table 9.3.2-1 presents the equations and the area of their applicability, the reader is strongly urged to examine Herb's (1981) report before attempting to apply the equations. 
Table 9.3.2-1 Equations for estimating mean discharges for ungaged, unregulated streams.

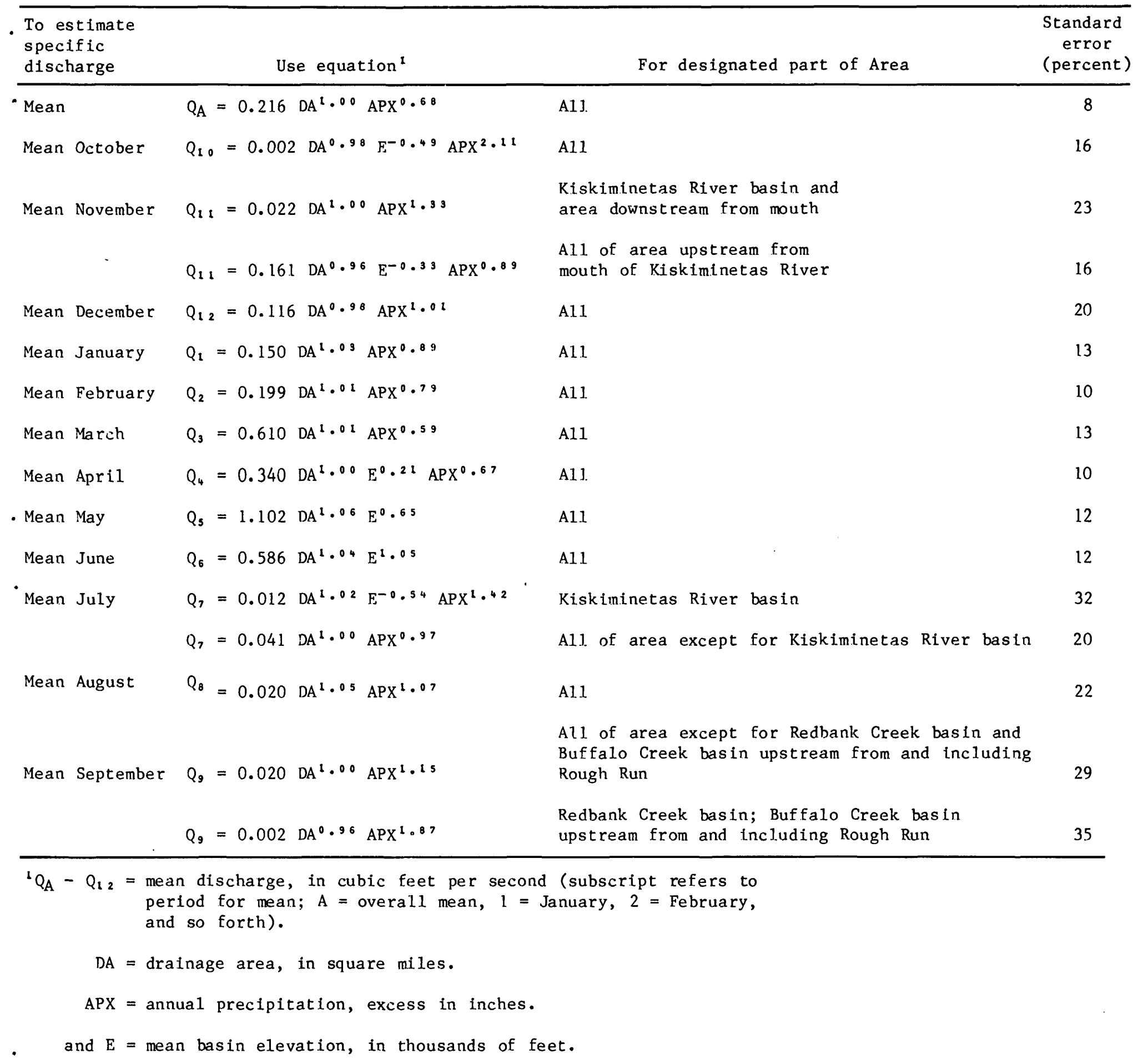




\subsection{SURFACE-WATER QUANTITY (Continued) \\ 9.4 Peak Flows \\ 9.4.1 Gaged Sites}

\section{PEAK FLOW DATA ARE AVAILABLE FOR 23 GAGED STREAMS}

\section{Peak flow data have been collected and analyzed for 23 gaged streams in Area 3 to provide estimates of the probabilities of selected peak flows.}

Peak flow data have been collected at 23 gaging stations in Area 3 during recent years. These data have been analyzed by procedures outlined by the Water Resources Council (1976) to develop estimates of the probabilities of floods of various magnitudes for each stream at five specific exceedance probabilities. The peak discharges at selected exceedance probabilities for the gaging stations are presented in table 9.4.1-1.

Exceedance probability is the probability that a flood of a given magnitude will be exceeded in a given year. For example, table 9.4.1-1 shows a flood peak of $265 \mathrm{ft}^{3} / \mathrm{s}$ (cubic feet per second) at an exceedance probability of 10 percent for site 12 . This can be interpreted to mean that in any given year site 12 has a one in ten chance of having a maximum peak greater than $265 \mathrm{ft}^{3} / \mathrm{s}$. Exceedance probability is the inverse, expressed in percent, of the previously used "t-year" flood. The 10-percent flood corresponds to the formerly used 10-year flood, the 1-percent flood corresponds to the 100-year flood, and so forth.

The estimates presented in table 9.4.1-1 are based upon data collected at each station and a regional value of the skew of the flood-peak distribution. The estimates do not include any other regional adjustment factors. As the length of record at the stations increases, the estimates of flood magnitudes will probably improve. A more detailed discussion of peak flow estimates is given by Flippo (1977).

A knowledge of the probability associated with floods of various magnitudes is vital for the safe and economical design of such structures as culverts, sediment ponds, dams, and so forth. 
Table 9.4.1-1 Peak discharge at selected exceedance probabilities for gaging stations.

\begin{tabular}{|c|c|c|c|c|c|c|}
\hline \multicolumn{7}{|c|}{ Discharge at specified exceedance probability $(\mathrm{ft} / \mathrm{s})$} \\
\hline \multirow{2}{*}{$\begin{array}{l}\text { Site } \\
\text { Number }\end{array}$} & \multirow{2}{*}{$\begin{array}{c}\text { Station } \\
\text { Number }\end{array}$} & \multicolumn{5}{|c|}{ Exceedance probability (percent) } \\
\hline & & 43 & 10 & 4 & 2 & 1 \\
\hline 11 & 03031780 & 170 & 265 & -- & -- & -- \\
\hline 16 & 03031950 & 485 & 812 & -- & -- & -- \\
\hline 20 & 03032500 & 13,400 & 23,100 & 29,100 & 33,800 & 38,700 \\
\hline 26 & 03034000 & 4,620 & 7,570 & 9,370 & 10,800 & 12,200 \\
\hline 27 & 03034500 & 3,350 & 5,170 & 6,240 & 7,050 & 7,870 \\
\hline 40 & 03038000 & 5,670 & 9,330 & 11,600 & 13,300 & 15,000 \\
\hline 42 & 03039000 & 9,660 & 15,200 & 18,400 & 20,900 & 23,400 \\
\hline 43 & 03039200 & 130 & 230 & -- & -- & -- \\
\hline 52 & 03040000 & 11,700 & 21,400 & 27,900 & 33,300 & -- \\
\hline 56 & 03041000 & 6,370 & 10,200 & 12,500 & 14,300 & -- \\
\hline 58 & 03041500 & 21,400 & 35,100 & 43,600 & 50,200 & -- \\
\hline 65 & 03042000 & 7,150 & 12,300 & 15,500 & 18,100 & -- \\
\hline 68 & 03042170 & 295 & 435 & -- & -- & -- \\
\hline 70 & 03042200 & 405 & 650 & -- & -- & -- \\
\hline 73 & 03042500 & 5,690 & 8,900 & 10,800 & -- & -- \\
\hline 75 & 03044000 & 36,100 & 55,800 & -- & -- & - \\
\hline 79 & 03045000 & 6,990 & 12,500 & 16,100 & 18,900 & 21,900 \\
\hline 94 & 03049000 & 4,550 & 7,640 & 9,480 & 10,900 & 12,300 \\
\hline 95 & 03049100 & 273 & 360 & -- & -- & - \\
\hline 96 & 03049500 & 145,000 & 205,000 & 235,000 & 255,000 & -- \\
\hline
\end{tabular}
9.0 SURFACE-WATER QUANTITY (CONTINUED) 9.4 PEAK FLOW




\subsection{SURFACE-WATER QUANTITY (Continued) \\ 9.4 Peak Flows (Continued) \\ 9.4.2 Ungaged Sites}

\section{PEAK FLOWS CAN BE ESTIMATED FOR UNGAGED SITES}

\section{Peak flows for selected exceedance probabilities can be estimated for ungaged sites if certain basin and climatic parameters are known.}

Peak flows can be estimated for ungaged sites at exceedance probabilities (reciprocal of recurrence interval) of $43,10,4,2$, and 1 percent, using regression equations (table 9.4.2-1) developed by Flippo (1977). These equations were developed and calibrated using data from many gaged streams in and around Area 3. The data required to use these equations are drainage area, mean annual preciptation, and potential annual evapotranspiration. These data can be determined from topographic maps and the maps presented by Flippo (1977). The reliability of these equations for drainage areas smaller than 2 square miles is unknown.
An alternate procedure can be used to estimate peak flows at exceedance probabilities of 10,4 , and 2 percent using regression equations developed by Herb (1977). These alternate regression equations presented in table 9.4.2-2 use channel width as the independent variable. The equations can be used directly, but the reader is urged to review Herb (1977) before attempting their use. The reliability of these equations for drainage areas smaller than $2 \mathrm{mi}^{2}$ is unknown. 
Table 9.4.2-1 Regression equations for peak discharge estimation.

\begin{tabular}{llll}
\multicolumn{2}{c}{ Equation } & Standard Error \\
\hline $\mathrm{P}_{43}=39.4$ & $\mathrm{DA} \cdot 827$ & $\mathrm{APX} \cdot 222$ & 28 \\
$\mathrm{P}_{10}=45.4 \mathrm{DA} \cdot 789$ & $\mathrm{APX} \cdot 445$ & 25 \\
$\mathrm{P}_{04}=45.3 \mathrm{DA} \cdot 772$ & $\mathrm{APX} \cdot 556$ & 26 \\
$\mathrm{P}_{02}=44.5 \mathrm{DA} \cdot 759$ & $\mathrm{APX} \cdot 656$ & 29 \\
$\mathrm{P}_{01}=42.2 \mathrm{DA} \cdot 751$ & $\mathrm{APX} \cdot 744$ & 31 \\
\hline
\end{tabular}

Table 9.4.2-2 Regression equations for peak discharge estimation.

\begin{tabular}{c} 
Equation \\
$\mathrm{P}_{10}=7.079 \mathrm{CWIDE}^{1.473}$ \\
$\mathrm{P}_{04}=10.641 \mathrm{CWIDE}^{1.151}$ \\
$\mathrm{P}_{02}=14.028 \mathrm{CWIDE}^{1.437}$ \\
\hline
\end{tabular}

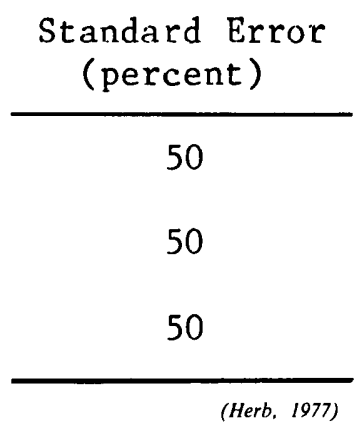

Where $\mathrm{P}_{43}-\mathrm{P}_{01}=$ Peak discharge, in cubic feet per second, for flood with specified exceedance probability (subscript 43 indicates a 43 percent chance of being exceeded in a given year, 10 indicates a 10 percent chance of being exceeded in a given year, and so forth),

$\mathrm{DA}=$ Drainage area, in square miles,

$\mathrm{APX}=$ Annual precipitation excess, in inches, computed by subtracting annual potential evapotranspiration from mean annual precipitation, and

CWIDE $=$ Top width of bankfull channel, in feet.

\subsection{SURFACE-WATER QUANTITY (CONTINUED)




\subsection{SURFACE-WATER QUANTITY (Continued) \\ 9.4 Peak Flows (Continued) \\ 9.4.3 Flood-Prone Areas}

\section{FLOOD-PRONE AREA MAPS AVAILABLE FOR AREA}

\section{Flood-prone area maps are available for 84 of $10071 / 2$-minute quadrangle maps covering Area 3.}

The National Flood Insurance Act of 1968 and the Flood Disaster Protection Act of 1973 established programs for identifying towns and streams subject to flood problems and for outlining flood-prone areas on topographic maps by approximate methods. In 1968 the Geological Survey began delineating flood-prone areas of the maximum known flood on $71 / 2$-minute topographic quadrangle maps using existing information. After 2 years it was decided that areal uniformity of the flood delineated would be desirable, so the 100-year flood (1-percent exceedance probability flood) was selected for mapping in 1970.
The depth of the 1-percent exceedance probability flood was determined for selected streams throughout Pennsylvania through the use of existing topographic quadrangle maps in the area.

Copies of the flood-prone area maps may be obtained from:

\author{
U.S. Geological Survey \\ Water Resources Division \\ P.O. Box 1107 \\ Harrisburg, Pennsylvania 17108
}




\begin{tabular}{cccc}
0 & 10 & 20 & 30 \\
\hline & 10 & 20 & 30 KILOMETERS
\end{tabular}

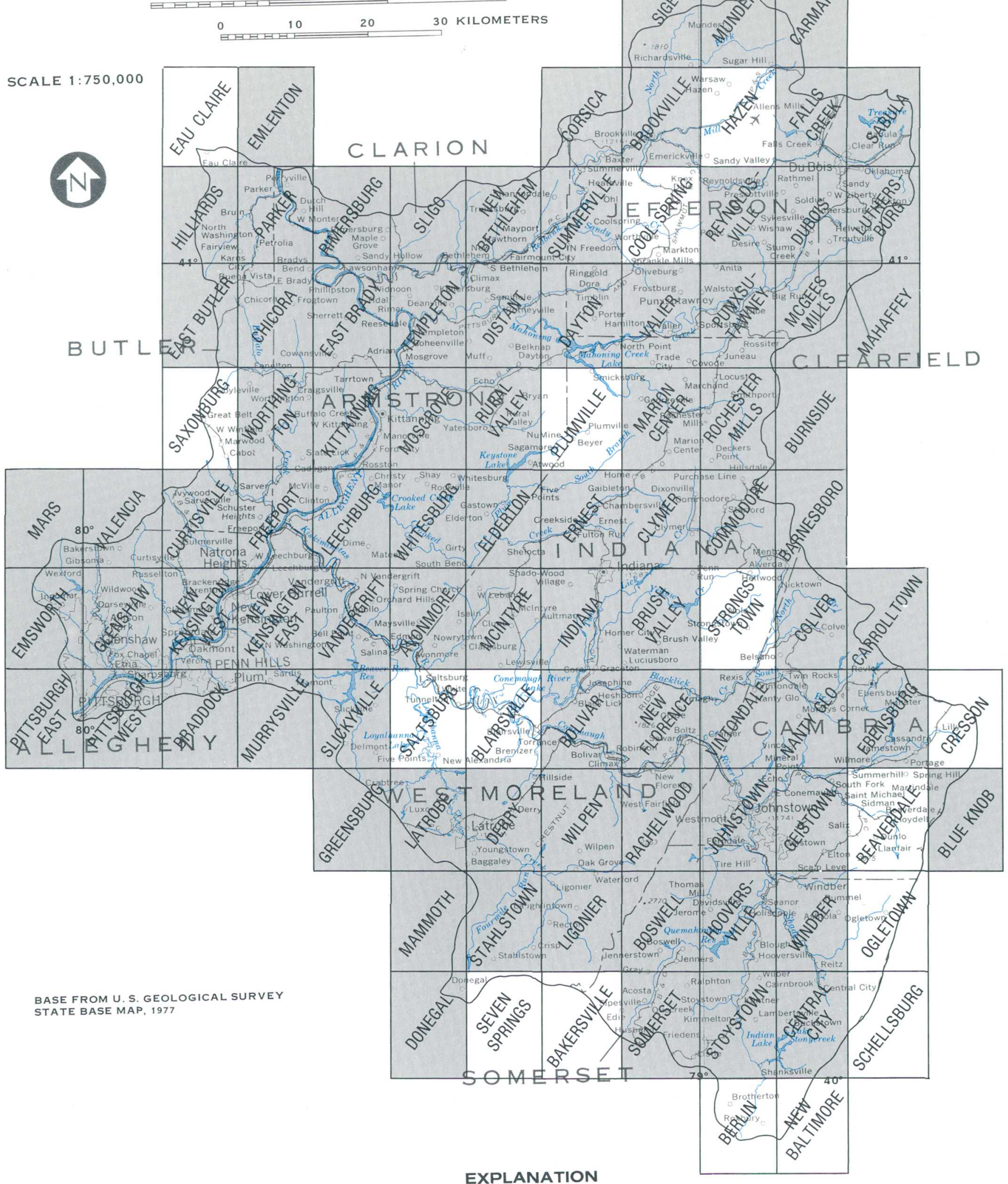

EXPLANATION

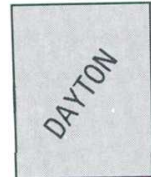

Flood-prone area map

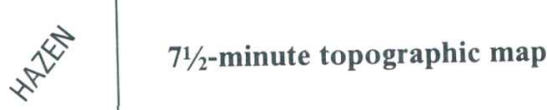

Figure 9.4.3-1 Flood-prone area maps.

9.0 SURFACE-WATER QUANTITY (CONTINUED) 


\title{
9.0 SURFACE-WATER QUANTITY (Continued) \\ 9.5 Flow Duration \\ 9.5.1 Gaged Sites
}

\section{FLOW DURATION CURVES SUMMARIZE LONG-TERM DAILY DISCHARGE DATA}

\author{
Flow-duration analysis summarizes \\ many years of hydrologic records.
}

Figure 9.5.1-1 presents flow duration curves for eight stations in Region 3 that had 10 or more years of record unaffected by significant regulation or diversion. The period of record used in the flow-duration computation is indicated with each curve. The curves illustrate the discharges which were exceeded for the range in probabilities from 2 percent to 98 percent. The discharge values presented in these figures are mean daily discharges in cubic feet per second.

A flow-duration curve is a cumulative frequency curve which shows the percentage of time a specific daily discharge was exceeded during a given period of record (Searcy, 1959). Such curves do not indicate the sequence of the flow events, but they do present a picture of the discharge characteristics of a stream over a wide range of recorded flow conditions. If the period of record used to prepare a flow-duration curve is representative of long-term flow conditions, the curve will be applicable to the long-term.

Flow duration data have a wide variety of applications. These applications may include the design of water-retaining structures or the computation of long term yields of constituents such as suspended sediment or dissolved iron if the appropriate transport curves are known. 

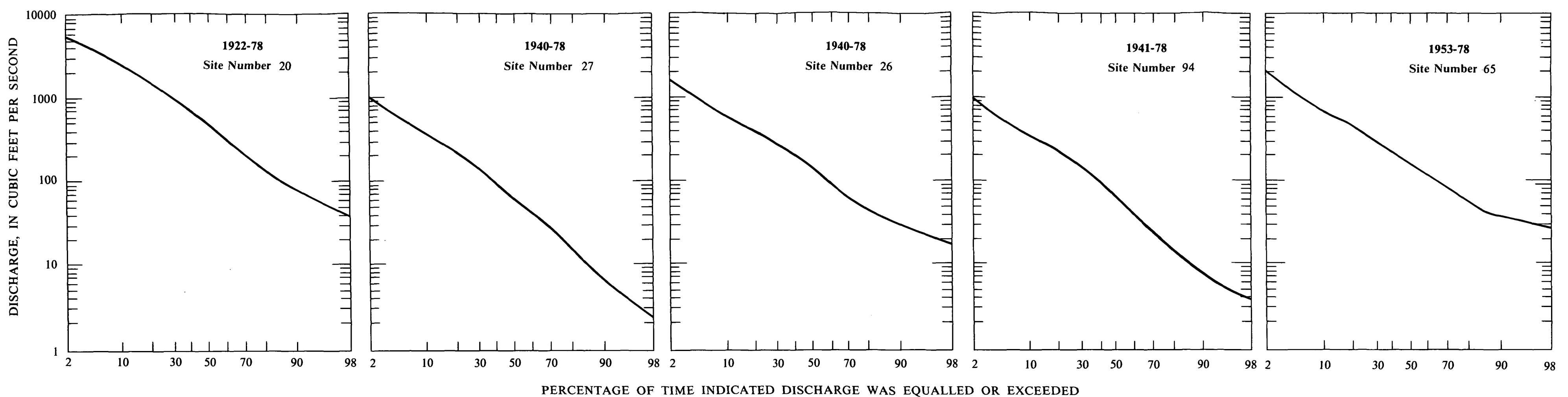

PERCENTAGE OF TIME INDICATED DISCHARGE WAS EQUALLED OR EXCEEDED
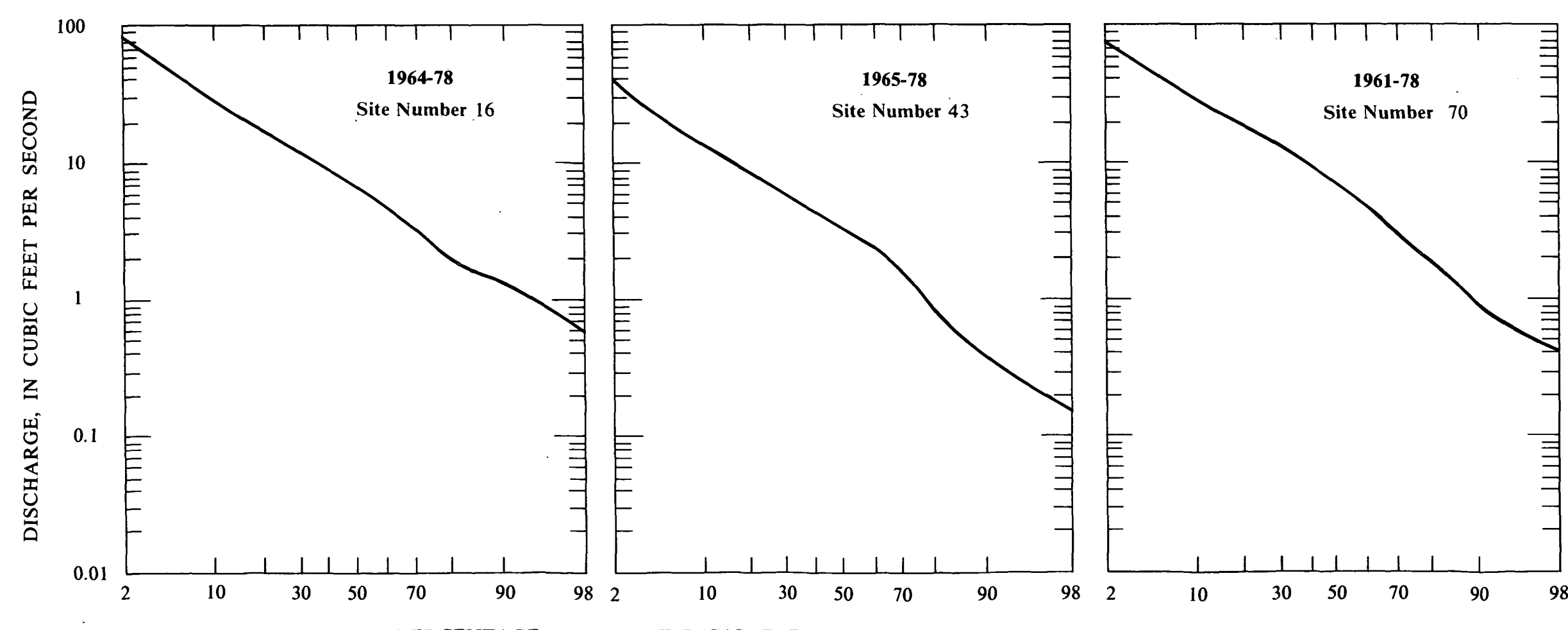

PERCENTAGE OF TIME INDICATED DisCHARge WAS EQUALLED OR EXCEEDED

Figure 9.5.1-1 Flow-duration curves for selected continuous-record stations.

9.0 SURFACE-WATER QUANTITY (CONTINUED) 9.5 FLOW DURATION 


\title{
9.0 SURFACE-WATER QUANTITY (Continued) \\ 9.5 Flow Duration (Continued) \\ 9.5.2 Ungaged Sites
}

\section{FLOW DURATION CAN BE ESTIMATED FOR UNGAGED SITES}

\author{
Flow duration can be estimated at ungaged \\ sites using a simple graph along with \\ information on the size of the drainage basin.
}

Figure 9.5.2-1 is a composite unit flow-duration curve for five gaging stations having drainage areas less than $90 \mathrm{mi}^{2}$ (square miles) in or near Region 3. The flow duration data are presented in units of discharge of $\left(\mathrm{ft}^{3} / \mathrm{s}\right) / \mathrm{mi}^{2}$ (cubic feet per second per square mile). This method of presentation allows comparison of flow durations for streams having different drainage areas. The shaded area delineates the range of unit discharges observed at the five selected stations. The mean of the unit discharges at the various durations is the solid line in the center of the ranges shown.

The composite curve was drawn using computed flow durations for gaged streams having drainage areas ranging from 3.68 to $87.4 \mathrm{mi}^{2}$. This is the approximate range of drainage areas for the synoptic sites in Region 3. With some caution it is possible to use figure 9.5.2-1 to estimate points on a flow duration curve for any ungaged site where the drainage area is known and flow regulation is not a factor.

For example, suppose we wish to construct a flow duration curve for site 3 , a water-quality sam- pling site. The drainage area at this site is $16.5 \mathrm{mi}^{2}$. Selecting the approximate mid-point of the range on the curve in figure 9.5.2-1 gives unit discharges of $10.5,2.4,0.92,0.23$, and 0.05 at exceedance probabilities of 2, 20,50, 80, and 98percent, respectively. Multiplying these unit values by the drainage area of $16.5 \mathrm{mi}^{2}$ gives discharges of $170,40,15,3.8$, and 0.8 cubic feet per second at the specified points on the flow duration curve. More points could be calculated to better define the shape of the curve.

Caution should be exercised when using this procedure, because of the limited sample size used in developing the composite curve. Because the vertical scale is logarithmic, a straight line interpolation between the upper and lower curves to get the mean value will generally underestimate the mean.

Searcy (1959) presents an alternate method for developing a unit flow-duration curve. However, Searcy's method requires a knowledge of the stream's mean flow before an estimate can be made. 


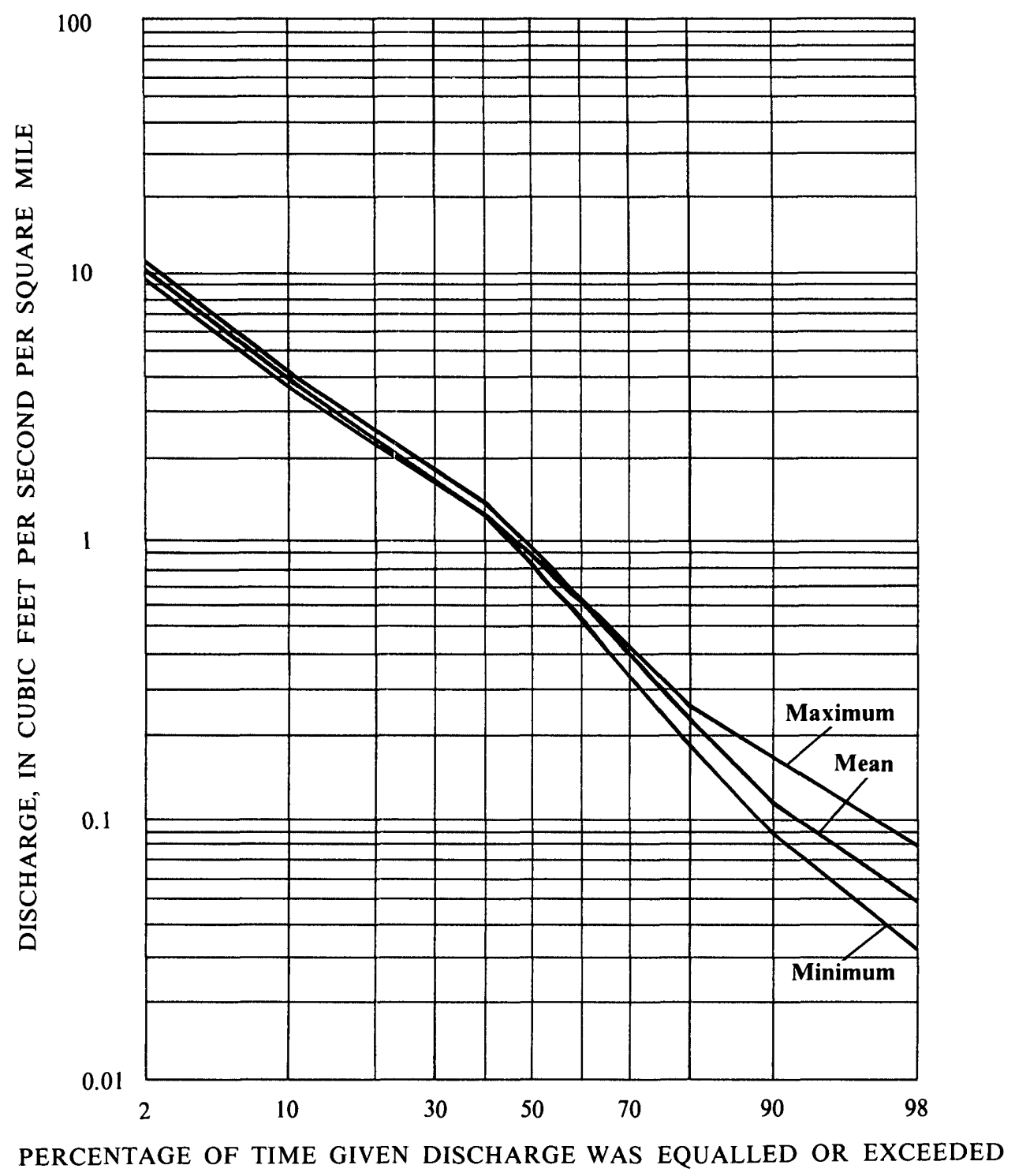

Figure 9.5.2-1 Composite flow-duration curves. 


\title{
10.0 GROUND-WATER LEVELS
}

\section{GROUND-WATER LEVELS LOWEST IN EARLY FALL}

\author{
Water levels in observation wells fluctuate seasonally. \\ Highest levels are found in March to May and lowest \\ levels are found in September to November.
}

Figure 10.0-1 shows the locations of five ground-water observation wells in Eastern Coal Province Area 3. Water level data are collected at these wells on a continuous basis.

Figure 10.0-2 illustrates the variability in ground-water levels during the 1978 and 1979 water years. The curves are constructed from data at 5-day intervals, so there is some smoothing effect. The water level in some wells, such as JE 23, shows only minimal fluctuation over the period while other wells, such as CA 1 , shows wide fluctuation. The dif- ferences in the fluctuations among the different wells are attributable to differences in hydraulic properties and pumping.

Ground-water levels in the observation wells are usually lowest during September to November with the lowest levels occurring around the beginning of October. Following the October low, there generally is an increase in ground-water levels until a maximum is reached during March to May. 


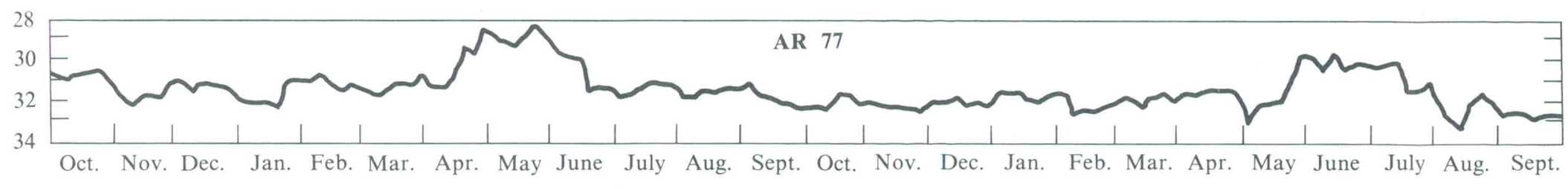

1978

WATER YEAR

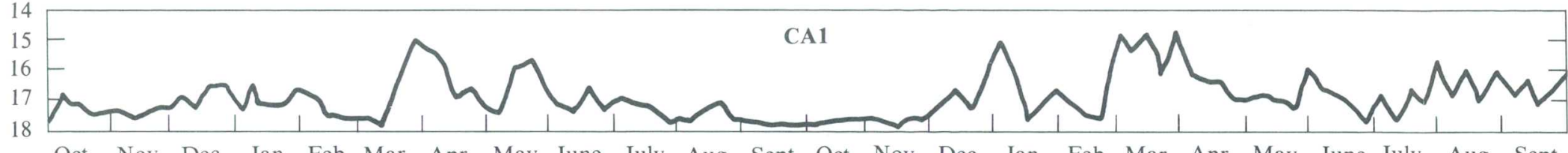

Oct. Nov. Dec. Jan. Feb. Mar. Apr. May June July Aug. Sept. Oct. Nov, Dec. Jan. Feb. Mar. Apr. May June July Aug. Sept.

1978 WATER YEAR

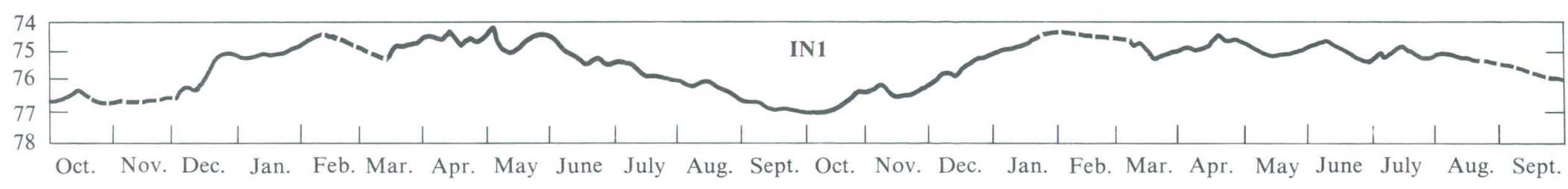
1978

\section{TER YEAR}

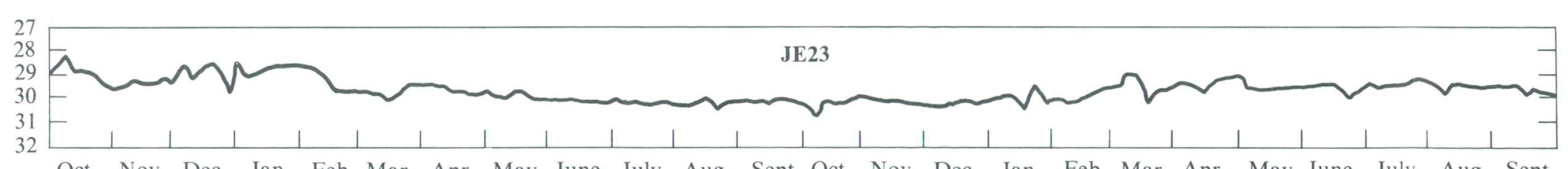

Oct. Nov. Dec. Jan. Feb. Mar. Apr. May June July Aug. Sept. Oct. Nov. Dec. Jan. Feb. Mar. Apr. May June July Aug. Sept.

WATER YEAR

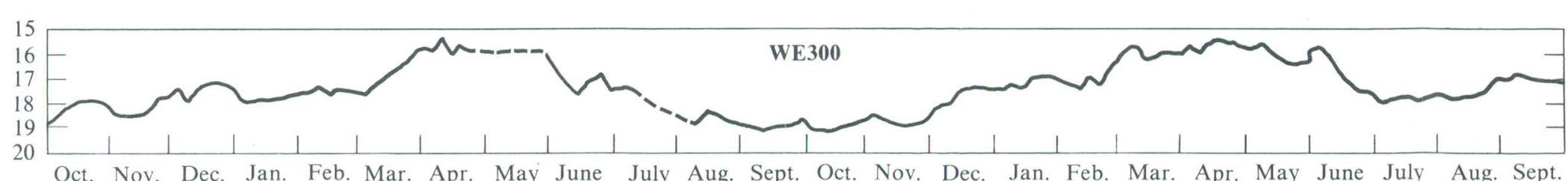

1978

WATER YEAR

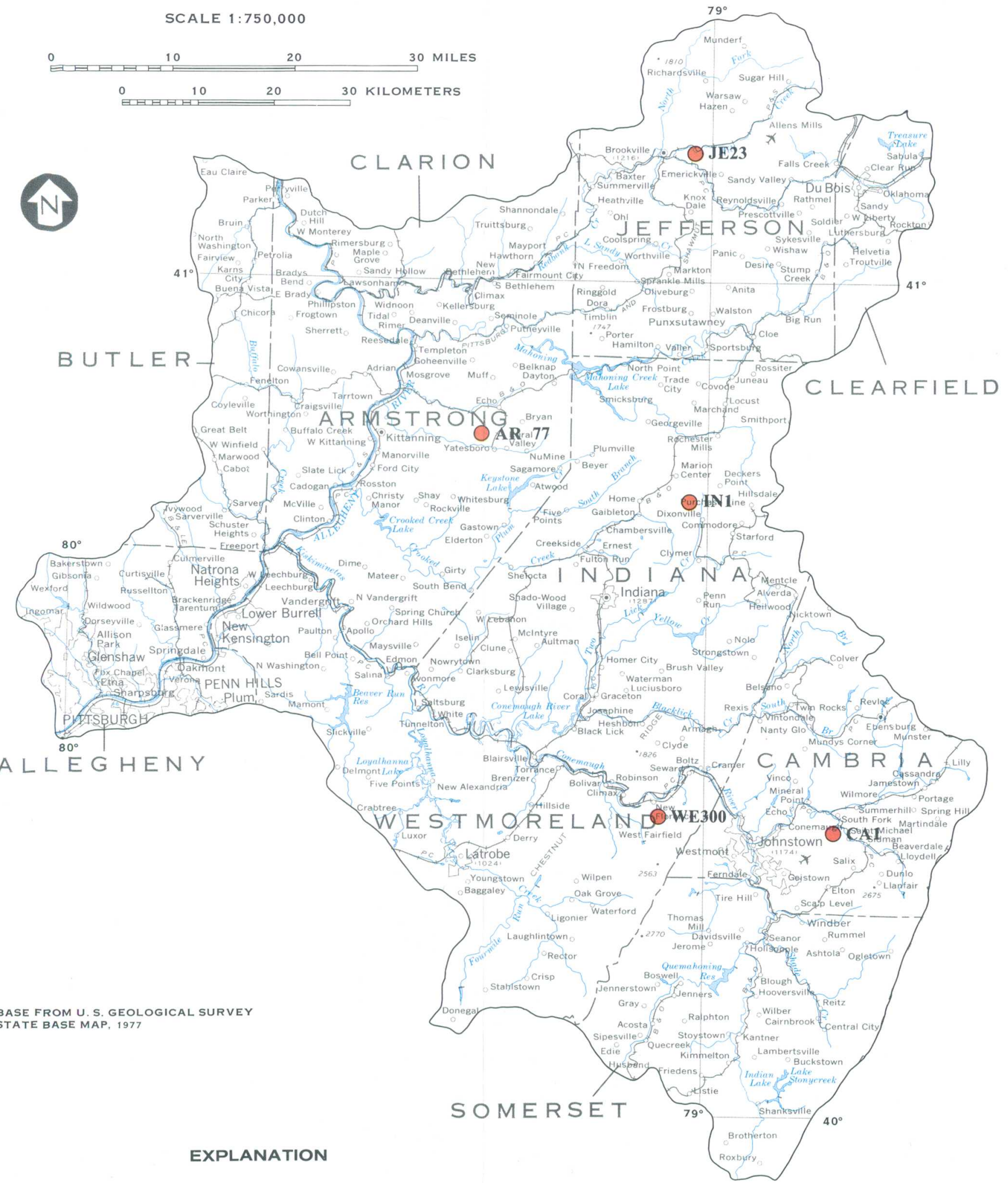

AR 77 Observation well and number

Figure 10.0-2 Variations in ground-water levels, 1978 and 1979 water years. 
. 


\title{
11.0 WATER-DATA SOURCES
}

11.1 Introduction

\section{NAWDEX, WATSTORE, OWDC HAVE WATER DATA INFORMATION}

\author{
Water data are collected in coal areas by large number of \\ organizations in response to a wide variety of missions and needs.
}

Within the U.S. Geological Survey there are three activities that help to identify and improve access to the vast amount of existing water data.

(1) The National Water Data Exchange (NAWDEX), which indexes the water data available for over 400 organizations and serves as a central focal point to help those in need of water data to determine what information already is available.

(2) The National Water Data Storage and Retrieval System (WATSTORE), which serves as the central repository of water data collected by the U.S. Geological Survey and which contains large volumes of data on the quantity and quality of both surface and ground waters.

(3) The Office of Water Data Coordination (OWDC), which coordinates Federal water-data acquisition activities and maintains a "Catalog of Information on Water Data." To assist in identifying available water-data activities in coal provinces of the United States special indexes to the Catalog are being printed and made available to the public.

A more detailed explanation of these three activities is given in sections 11.2, 11.3, and 11.4. 


\title{
11.0 WATER-DATA SOURCES (Continued) \\ 11.2 National Water Data Exchange--NAWDEX
}

\section{NAWDEX SIMPLIFIES ACCESS TO WATER DATA}

\author{
The National Water-Data Exchange (NAWDEX) is a nationwide program \\ managed by the U.S. Geological Survey to assist users of water data \\ or water-related data in identifying, locating, and acquiring needed data.
}

NAWDEX is a national confederation of wateroriented organizations working together to make their data more readily accessible and to facilitate a more efficient exchange of water data.

Services are available through a Program Office located at the U.S. Geological Survey's National Center in Reston, Virginia, and a nationwide network of Assistance Centers located in 45 States and Puerto Rico, which provide local and convenient access to NAWDEX facilities (see fig.11.2-1). A directory is available on request that provides names of organizations and persons to contact, addresses, telephone numbers, and office hours for each of these locations [Directory of Assistance Centers of the National Water Data Exchange (NAWDEX), U.S. Geological Survey Open-File Report 79-423 (revised)].

NAWDEX can assist any organization or individual in identifying and locating needed water data and referring the requester to the organization that retains the data required. To accomplish this service, NAWDEX maintains a computerized Master Water Data Index (fig. 11.2-2), which identifies sites for which water data are available, the type of data available for each site, and the organization retaining the data. A Water Data Sources Directory (fig. 11.2-3) also is maintained that identifies organizations that are sources of water data and the locations within these organizations from which data may be obtained. In addition NAWDEX has direct access to some large water-data bases of its members and has reciprocal agreements for the exchange of services with others.

Charges for NAWDEX services are assessed at the option of the organization providing the requested data or data service. Search assistance services are provided free by NAWDEX to the greatest extent possible. Charges are assessed, however, for those requests requiring computer cost, extensive personnel time, duplicating services, or other costs encountered by NAWDEX in the course of providing services. In all cases, charges assessed by NAWDEX Assistance Centers will not exceed the direct costs incurred in responding to the data request. Estimates of cost are provided by NAWDEX upon request and in all cases where costs are anticipated to be substantial.

For additional information concerning the NAWDEX program or its services contact:

Program Office

National Water Data Exchange (NAWDEX) U.S. Geological Survey 421 National Center 12201 Sunrise Valley Drive Reston, Virginia 22092

Telephone: (703) 860-6031 FTS 928-6031

Hours: 7:45-4:15 Eastern Time

or

U.S. Geological Survey

Water Resources Division 4th Floor, Federal Building P.O. Box 1107

Harrisburg, Pennsylvania 17108

Telephone: (717) 782-3851 FTS 590-3851

Hours: 8:00-4:00 Eastern Time 


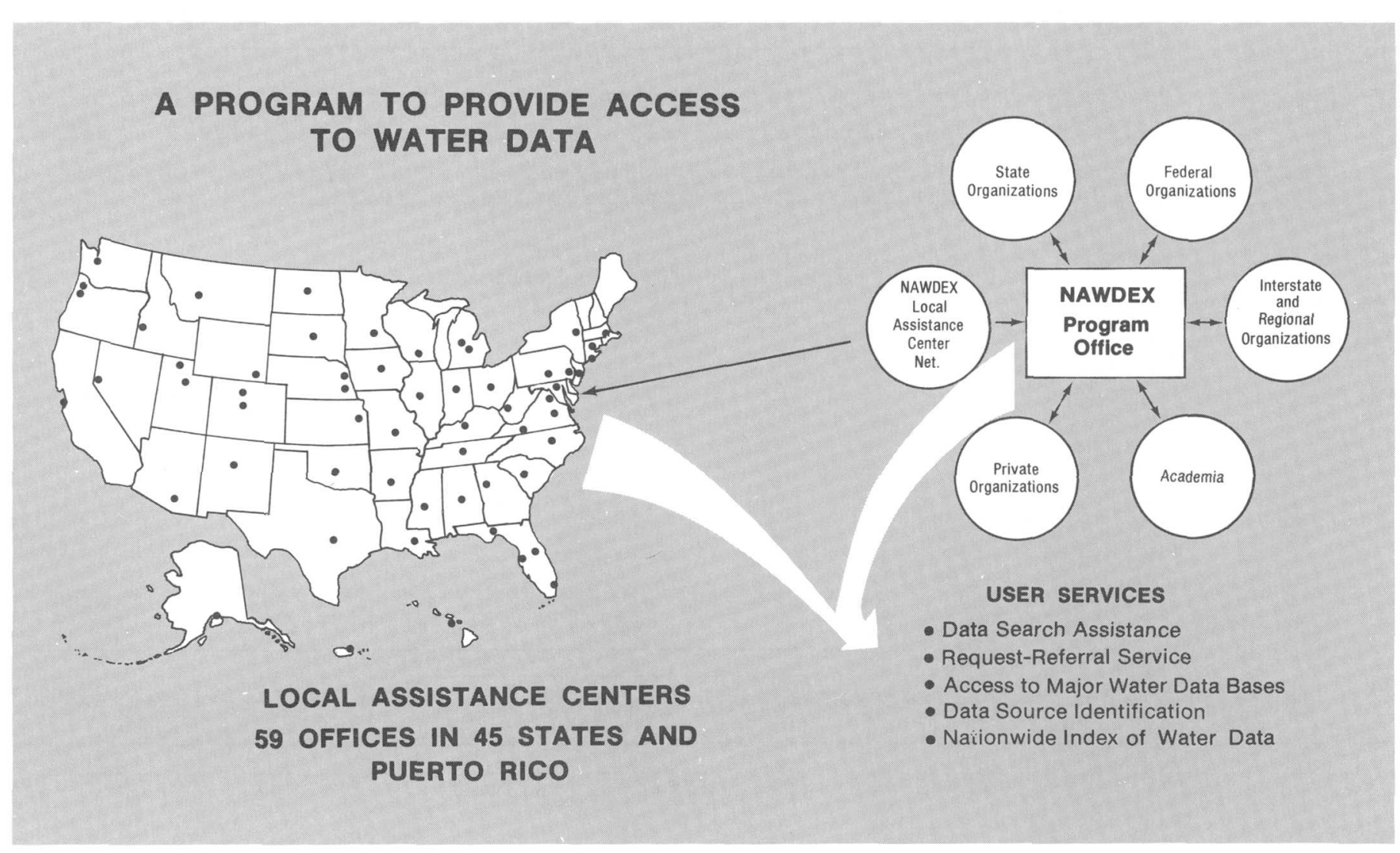

Figure 11.2-1 Access to water data.

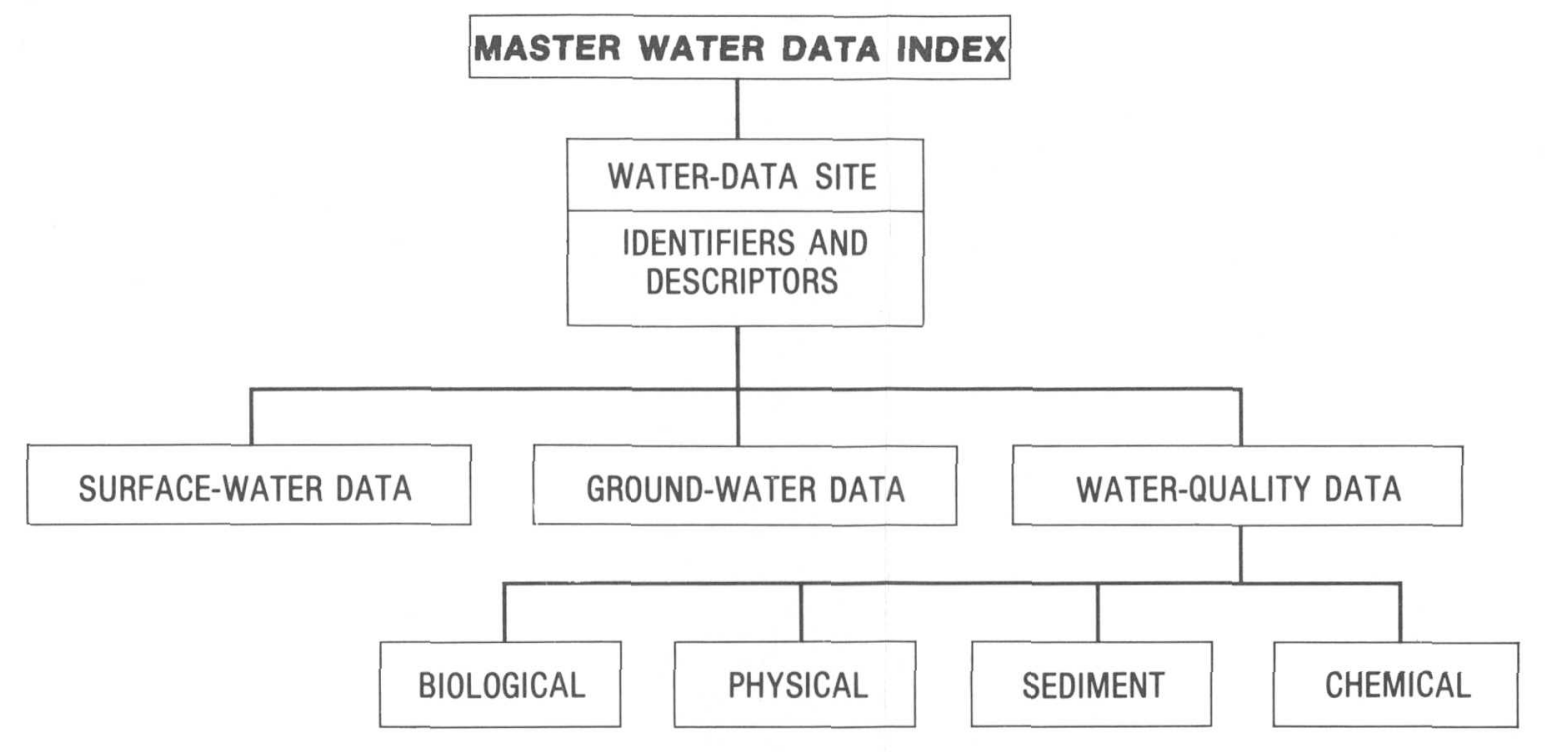

Figure 11.2-2 Master water-data index.

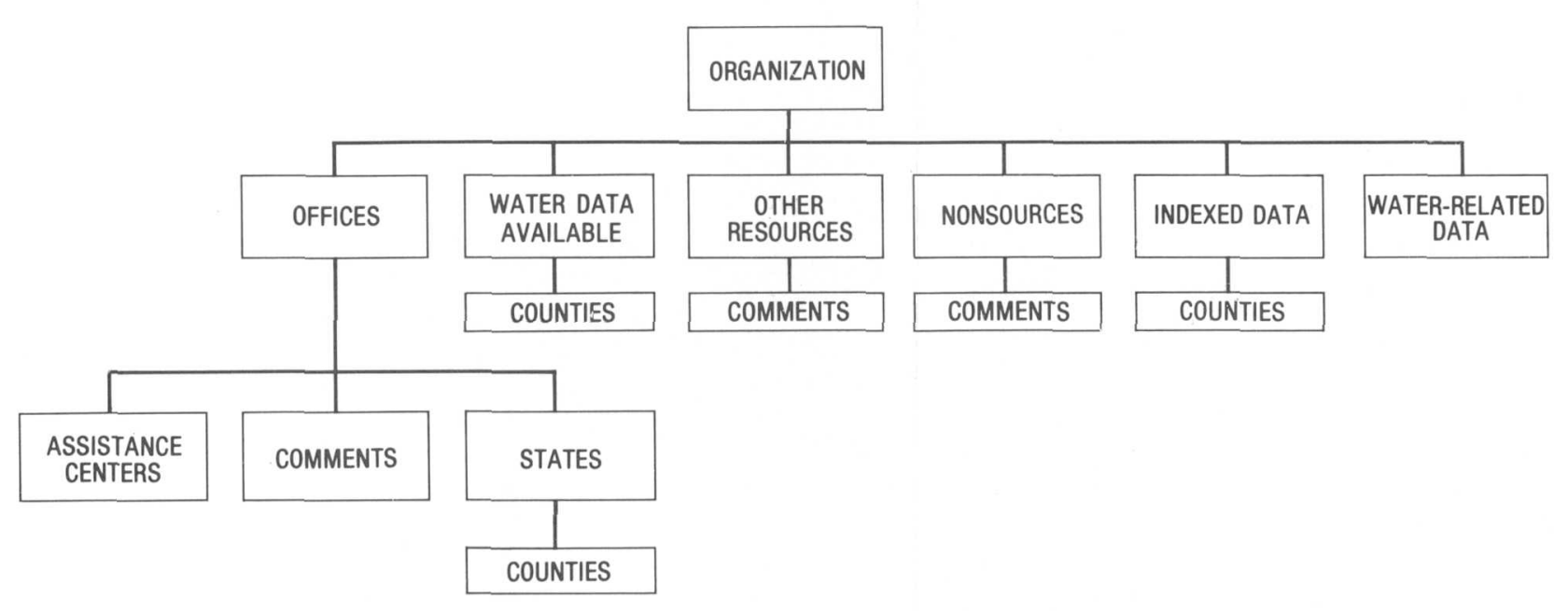

Figure 11.2-3 Water-data sources directory.

11.0 WATER-DATA SOURCES (CONTINUED)

11.2 NATIONAL WATER DATA EXCHANGE-NAWDEX 


\title{
11.0 WATER-DATA SOURCES (Continued) 11.3 WATSTORE
}

\section{WATSTORE AUTOMATED DATA SYSTEM}

\author{
The National Water Data Storage and Retrieval System (WATSTORE) \\ of the U.S. Geological Survey provides computerized procedures \\ and techniques for processing water data and provides effective \\ and efficient management of data-releasing activities.
}

The National Water Data Storage and Retrieval System (WATSTORE) was established in November 1971 to computerize the U.S. Geological Survey's existing water-data system and to provide for more effective and efficient management of its data-releasing activities. The system is operated and maintained on the central computer facilities of the Survey at its $\mathrm{Na}$ tional Center in Reston, Virginia. Data may be obtained from WATSTORE through the Water Resources Division's 46 district offices. General inquiries about WATSTORE may be directed to:

Chief Hydrologist

U.S. Geological Survey

437 National Center

Reston, Virgina 22092

or

\section{U.S. Geological Survey \\ Water Resources Division \\ 4th Floor, Federal Building \\ I P.O. Box 1107 \\ Harrisburg, Pennsylvania 17108}

The Geological Survey currently (1980) collects data at approximately 16,000 stream gaging stations, 1,000 lakes and reservoirs, 5,200 surface-water quality stations, 1,020 sediment stations, 30,000 waterlevel observation wells, and 12,500 ground-water quality wells. Each year many water-data collection sites are added and others are discontinued; thus, large amounts of diversified data, both current and historical, are amassed by the Survey's data-collection activities.

The WATSTORE system consists of several files in which data are grouped and stored by common characteristics and data-collection frequencies. The system also is designed to allow for the inclusion of additional data files as needed. Currently, files are maintained for the storage of: (1) surface-water, quality-of-water, and ground-water data measured on a daily or continuous basis; (2) annual peak values for streamflow stations; (3) chemical analyses for surface- and ground-water sites; (4) water parameters measured more frequently than daily; and (5) geologic and inventory data for ground-water sites. In addition, an index file of sites for which data are stored in the system is also maintained (fig. 11.3-1). A brief description of each file is as follows.

Station Header File: All sites for which data are stored in the Daily Values, Peak Flow, Water-Quality, and Unit Values files of WATSTORE are indexed in this file. It contains information pertinent to the identification, location, and physical description of nearly 220,000 sites.

Daily Values File: All water-data parameters measured or observed either on a daily or on a continuous basis and numerically reduced to daily values are stored in this file. Instantaneous measurements at fixed-time intervals, daily mean values, and statistics such as daily maximum and minimum values also may be stored. This file currently contains over 200 million daily values including data on streamflow, river stages, reservoir contents, water temperatures, specific conductance, 'sediment concentrations, sediment discharges, and ground-water levels.

Peak Flow File: Annual maximum (peak) streamflow (discharge) and gage height (stage) values at surface-water sites comprise this file, which currently contains over 400,000 peak observations.

Water-Quality File: Results of over 1.4 million analyses of water samples that describe the chemical, physical, biological, and radiochemical characteristics of both surface and ground waters are contained in this file. These analyses contain data for $\mathbf{1 8 5}$ different constituents.

Unit Values File: Water parameters measured on a schedule more frequent than daily are stored in this file. Rainfall, stream discharge, and temperature 
data are examples of the types of data stored in the Unit Values File.

Ground-Water Site-Inventory File: This file is files discussed above, but it is cross-referenced to the Water-Quality File and the Daily Values File. It contains inventory data about wells, springs, and other sources of ground water. The data included are site location and identification, geohydrologic characteristics, well-construction history, and one-time field designed to accommodate 255 data elements and currently contains data for nearly 700,000 sites.

All data files of the WATSTORE system are maintained and managed on the central computer facilities of the Geological Survey at its National trieved from WATSTORE at a number of oor that are part of a nationwide telecommunication network.

Remote Job Entry Sites: Almost all of the Wate Resources Division's district offices are equipped cess to the WATSTORE system. These terminals aclow each site to put data into or retrieve data from the system within several minutes to overnight, depending upon the priority placed on the request. The number of remote job entry sites is increased as the need arises.

Digital Transmission Sites: Digital recorders are used at many field locations to record values for parameters such as river stages, conductivity, water temperature, turbidity, wind direction, and chlorides. Data are recorded on 16-channel paper tape, Which is removed from the recorder and transmitted The data are recorded the recliver at Reston, $V$. the central computer. Extensive testing of satellite data collection platforms indicates their feasibility for collecting real-time hydrologic data on a nationa scale. Battery-operated radios are used as the constations are being operated currently (1980).

Central Laboratory System: The Water Resources Division's two water-quality laboratories,
located in Denver, Colorado, and Atlanta, Georgia, analyze more than 150,000 water samples per year. These laboratories ars equipped to automatically per-

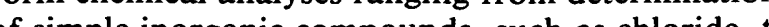

complex organic compounds, such as pesticides. As each analysis is completed, the results are verified by laboratory personnel and transmitted via a conputer stored in the Water-Quality File of WATSTORE.

Water data are used in many ways by decisionmakers for the management, development, and monitoring of our water resources. In addition to its data processing, storage, and retrieval capabilities, WATSO ra can provide a varicty of useful tatistical analyses. A minimal fee, plus the actual computer cost incurred in producing a desired product, is charged to the requester.

Computer-Printed Tables: Users most often request data from WATSTORE in the form of tables lists of actual cotaper. The in the for may contain the availability of data stored in the files. A variety of formats is available to display the many types of data.

Computer-Printed Graphs: Computer-printed graphs for the rapid analysis or display of data are rams are available to produce bar graphs (histograms), line graphs, frequency distribution curves, $X-Y$ point plots, site-location map plots, and other similar items by means of line printers.

Statistical Analyses: WATSTORE interfaces vide extensive analyses of data such as regression analyses, the analysis of variance, transformations, and correlations.

Digital Plotting: WATSTORE also makes use of software systems that prepare data for digital plotcentral computer site. Plots that can be obtained include hydrographs, frequency distribution curves, $\mathrm{X}-\mathrm{Y}$ point plots, contour plots, and three-dimensional plots.

Data in Machine-Readable Form: Data stored in WATSTORE can be obtained in machine-readable to user-written computer programs. These data are available in the standard storage format of the WATSTORE system or in the form of punched cards or card images on magnetic tape.

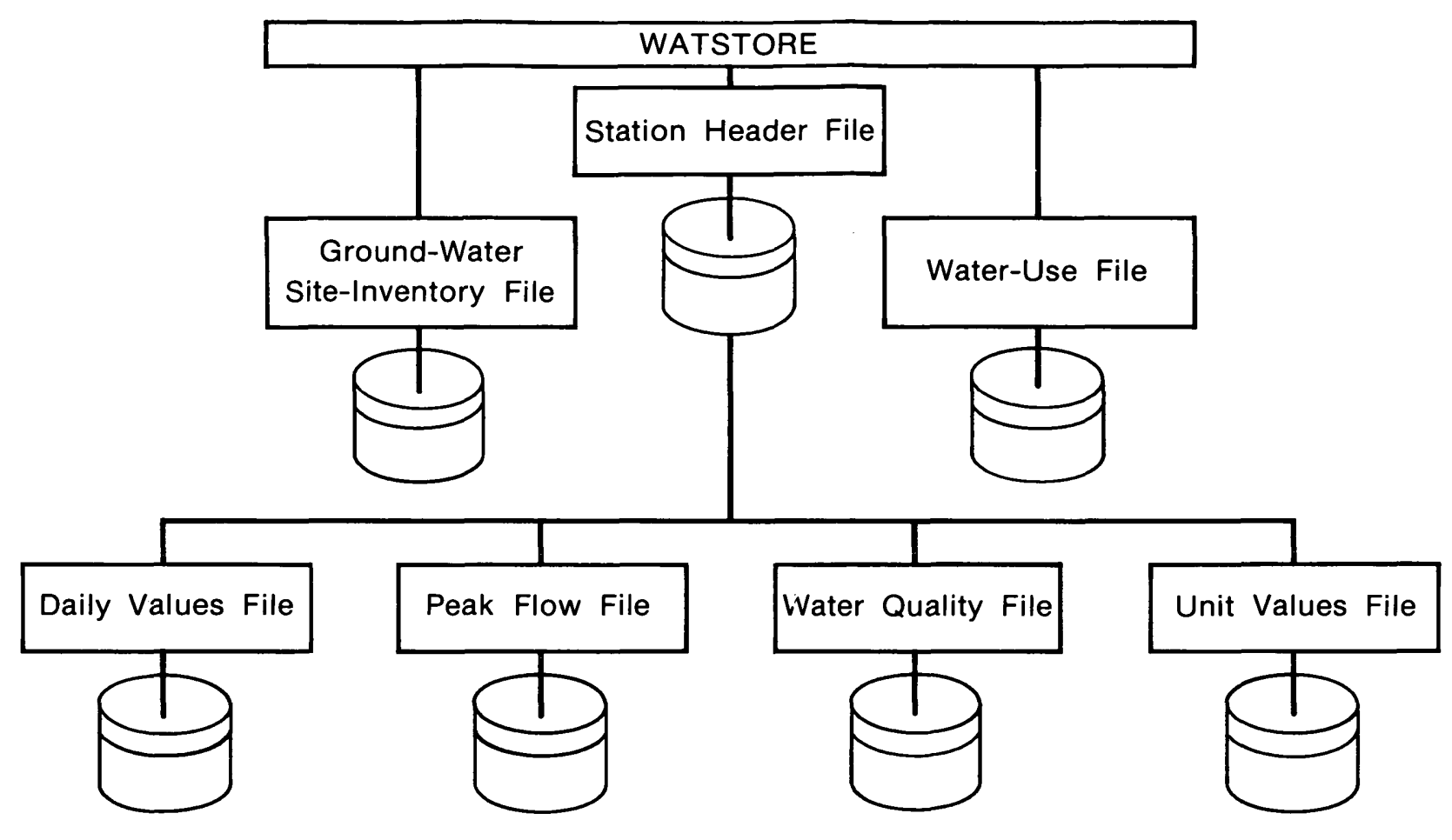

Figure 11.3-1 Index file stored data. 


\title{
11.0 WATER-DATA SOURCES (Continued) 11.4 Index to Water-Data Activities in Coal Provinces
}

\section{WATER DATA INDEXED FOR COAL PROVINCES}

\author{
A special index, "Index to Water-Data Activities in Coal \\ Provinces of the United States," has been published by the \\ U.S. Geological Survey's Office of Water Data Coordination (OWDC).
}

The "Index to Water-Data Activities in Coal Provinces of the United States" was prepared to assist those involved in developing, managing, and regulating the Nation's coal resources by providing information on the availability of water-resources data in the major coal provinces of the United States. It is derived from the "Catalog of Information on Water Data," which is a computerized information file about water-data acquisition activities in the United States, and its territories and possessions, with some international activities included.

This special index consists of five volumes (fig. 11.4-1): Volume I, Eastern Coal province; Volume II, Interior Coal province; Volume III, Northern Great Plains and Rocky Mountain Coal provinces; Volume IV, Gulf Coast Coal province; and Volume V, Pacific Coast and Alaska Coal provinces. The information presented will aid the user in obtaining data for evaluating the effects of coal mining on water resources and in developing plans for meeting additional water-data needs. The report does not contain the actual data; rather, it provides information that will enable the user to determine if needed data area available.

Each volume of this special index consists of four parts: Part A, Streamflow and Stage Stations; Part B, Quality of Surface-Water Stations; Part C, Quality of Ground-Water Stations; and Part D, Areal Investigations and Miscellaneous Activities. Information given for each activity in Parts A-C includes: (1) the identification and location of the station, (2) the major types of data collected, (3) the frequency of data collection, (4) the form in which the data are stored, and (5) the agency or organization reporting the activity. Part D summarizes areal hydrologic investigations and water-data activities not included in the other parts of the index. The agencies that submitted the information, agency codes, and the number of activities reported by type are shown in a table.

Those who need additional information from the Catalog file or who need assistance in obtaining water data should contact the National Water Data Exchange (NAWDEX) (See section 11.2).

Further information on the index volumes and their availability may be obtained from:

U.S. Geological Survey

Water Resources Division

4th Floor, Federal Building

P.O. Box 1107

Harrisburg, Pennsylvania 17108

Telephone (717) 782-3851 FTS 590-3851

or

Office of Surface Mining

U.S. Department of the Interior 603 Morris Street

Charleston, West Virginia 25301

Telephone: (304) 342-8125 FTS 924-7125 


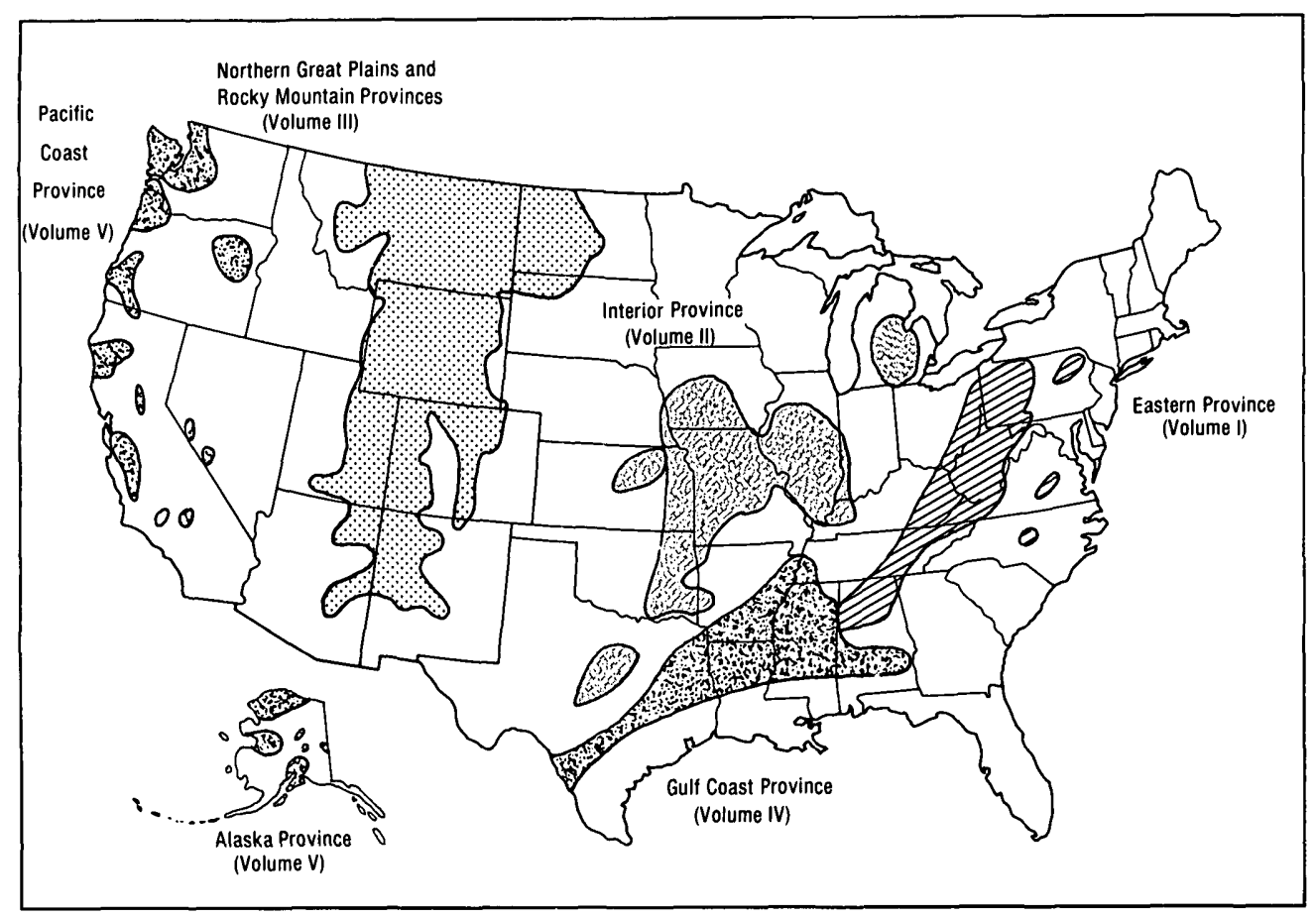

Figure 11.4-1 Index volumes and related provinces. 


\subsection{LIST OF REFERENCES}

Commonwealth of Pennsylvania, 1978, Annual report on mining, oil and gas, and land reclamation and conservation activities: Department of Environmental Resources, 387 p.

Feltz, H. R., 1980, Significance of bottom material data in evaluating water quality: Contaminants and Sediments, Volume 1, Baker, R. A., editor, Ann Arbor, Ann Arbor Science Publishers, p. 271-287.

Fenneman, N. M., 1938, Physiography of eastern United States: McGraw-Hill, New York, 714 p.

Flippo, H. N., Jr., 1977, Floods in Pennsylvania: Pennsylvania Department of Environmental Resources Water Resources Bulletin 13, 59 p.

---1981, Technical manual of low-flow frequency models for streams in Pennsylvania: U.S. Geological Survey Water-Resources Investigation (in press).

Harvard University, 1970, Oxygenation of ferrous iron: Water Pollution Control Research Series 14010-06/69, Federal Water Quality Administration, $199 \mathrm{p}$.

Hem, J. D., 1970, Study and interpretation of the chemical characteristics of natural water: U.S. Geological Survey, Water-Supply Paper 1473, second edition, $362 \mathrm{p}$.

Herb, W. J., 1977, Channel characteristics as flood predictors for selected forested watersheds in Pennsylvania and Maryland: Unpublished M.S. thesis, Pennsylvania State University.

---1981, Technical manual for estimating mean flow characteristics of Pennsylvania streams: Pennsylvania Department of Environmental $\mathrm{Re}$ sources, Water Resources Bulletin (in press).

International Joint Commission, 1979, Signs of progress: Great Lakes Focus vol. 5, issue 3, International Joint Commission, p. 9.

Miller, C. R., 1951, Analysis of flow-duration, sediment-rating curve method of computing sediment yield: U.S. Department of the Interior, Bureau of Reclamation, $55 \mathrm{p}$.

Office of Surface Mining, 1979, Surface coal mining and reclamation operations, permanent regulatory program: Federal Register, v. 44, no. 50, book 3, $153 \mathrm{p}$.

Pennsylvania Topographic and Geologic Survey, 1929, Map of the coal fields of Pennsylvania: Commonwealth of Pennsylvania.

---1960, Geologic map of Pennsylvania: Commonwealth of Pennsylvania. Porterfield, George, 1972, Computations of fluvial-sediment discharge: U.S. Geological Survey Techniques of Water Resources Investigations, Book 3, Chap. C3, $66 \mathrm{p}$.
Searcy, J. K., 1959, Flow-duration curves, manual of hydrology; Part 2, Low-flow techniques: U.S. Geological Survey Water-Supply Paper 1542-A, $33 \mathrm{p}$.

Sisler, J. D., 1961, Bituminous coal fields of Pennsylvania: Pennsylvania Geological Survey, Fourth Series, Bulletin M6, Third edition, 511 p.

Skougstad, M. W., Fishman, M. J., Friedman, L. C., Erdman, D. E., and Duncan, S. S., (editors), 1979, Methods for analysis or inorganic substances in water and fluvial sediments: U.S. Geological Survey Open-File Report 78-679, 626 p.

Snedecor, G: W., 1957, Statistical methods: Fifth edition, Ames, Iowa, Iowa State College Press, p. 174.

U.S. Department of Agriculture, 1968a, Soil survey, Indiana County, Pennsylvania: Soil Conservation Service, $110 \mathrm{p}$.

----1968b, Soil survey, Westmoreland County, Pennsylvania: Soil Conservation Service, 68 p.

U.S. Department of Commerce, 1973, Monthly normals of temperature, precipitation, and heating and cooling degree days 1941-70, Pennsylvania: National Oceanic and Atmospheric Administration, Environmental Data Service, Climatography of the United States, No. 81, 8 p.

U.S. Department of the Interior, 1968, Stream pollution by coal mine drainage upper Ohio River basin: Federal Water Pollution Control Administration, p. 110.

---1977, Guidelines for reclamation study areas: Bureau of Land Management, EMRIA Handbook, 1977.

U.S. Environmental Protection Agency, 1977, National interim primary drinking water regulations: Environmental Protection Agency Report 570/9-76-003, $159 \mathrm{p}$.

U.S. Geological Survey, 1979, Scientific and technical, spatial, and bibliographic data bases of the U.S. Geological Survey, 1979: U.S. Geological Survey Circular 817, 208 p.

---1980, Water resources data for Pennsylvania, Volume 3, Ohio and St.Lawrence River basins: U.S. Geological Survey Water-Data Report PA79-3, Water Year 1979, $386 \mathrm{p}$.

---1981, Water reources data for Pennsylvania, Volume 3, Ohio and St.Lawrence River basins: U.S. Geological Survey Water-Data Report PA80-3, Water Year 1980 (in press).

Wark, J. W., 1965, Sediment load of streams in the region, in Schneider, W.J., and others, Water resources of the Appalachian region, Pennsylvania 
to Alabama: U.S. Geological Survey Hydrologic Atlas HA-198.

Wilhm, J. L., and Dorris, J. C., 1968, Biological parameters for water quality criteria: BioScience, v. 18 , no. 6 , p. 477-480. 
Appendix 1 Station names and drainage areas for surface-water sites.

Site Number Station Number

Site Name

Drainage Area

(square miles)

\begin{tabular}{|c|c|c|c|}
\hline 1 & 03031500 & Allegheny River at Parker & 7671 \\
\hline 2 & 03031508 & South Branch Bear Creek at Bruin & 14.7 \\
\hline 3 & 03031510 & North Branch Bear Creek at Parker & 16.5 \\
\hline 4 & 03031540 & Sugar Creek at East Brady & 17.5 \\
\hline 5 & 03031550 & Haling Run at Van Buren & 10.8 \\
\hline 6 & 03031605 & Narrows Creek near Sabula & 7.2 \\
\hline 7 & 03031620 & Laborde Branch near Homecamp & 15.0 \\
\hline 8 & 03031650 & Kyle Run near Falls Creek & 2.46 \\
\hline 9 & 03031662 & Wolf Run at Falls Creek & 27.6 \\
\hline 10 & 03031720 & Trout Run near Reynoldsville & 10.0 \\
\hline 11 & 03031780 & Mi11 Creek near Brockway & 2.12 \\
\hline 12 & $0.3031870^{\circ}$ & Mill Creek at Brookville & 51.1 \\
\hline 13 & 03031871 & Five Mile Run at Brookville & 13.1 \\
\hline 14 & 03031873 & North Fork near Blowtown & 18.4 \\
\hline 15 & 03031900 & Beaver Run at Heathville & 9.78 \\
\hline 16 & 03031950 & Big Run at Sprankle Mills & 7.4 \\
\hline 17 & 03031951 & Big Run near Sprankle Mills & 10.6 \\
\hline 18 & 03032025 & Pine Creek at Mayport & 11.3 \\
\hline 19 & 03032400 & Leatherwood Creek near New Bethlehem & 17.9 \\
\hline 20 & 03032500 & Redbank Creek at St. Charles & 528 \\
\hline 21 & 03032757 & Wildcat Run at Diamond & 7.09 \\
\hline 22 & 03032770 & Fiddlers Run near Rimersburg & 5.33 \\
\hline 23 & 03033218 & Stump Creek near Big Creek & 25.8 \\
\hline 24 & 03033229 & Big Run at Big Run & 19.4 \\
\hline 25 & 03033390 & Canoe Creek at Cloe & 29.2 \\
\hline 26 & 03034000 & Mahoning Creek at Punxsutawney & 158 \\
\hline 27 & 03034500 & Little Mahoning Creek at McCormick & 87.4 \\
\hline 28 & 03036000 & Mahoning Creek at Mahoning Creek Dam & 344 \\
\hline 29 & 03036007 & Scrubgrass Creek at Gushenville & 6.78 \\
\hline 30 & 03036220 & North Branch South Fork Pine Creek at Echo & 11.0 \\
\hline 31 & 03036230 & South Branch South Fork Pine Creek near Bryan & 3.43 \\
\hline 32 & 03036300 & North Fork Pine Creek near Mosgrove & 3.42 \\
\hline 33 & 03036310 & North Fork Pine Creek at Mosgrove & 13.0 \\
\hline 34 & 03036320 & Limestone Run at Tarrtown & 10.2 \\
\hline 35 & 03036410 & Cowanshannock Creek near Sunnyside & 60.7 \\
\hline 36 & 03036500 & Allegheny River at Kittanning & 8973 \\
\hline 37 & 03036600 & Glade Run at Cadogan & 25.1 \\
\hline 38 & 03036995 & Crooked Creek above McKee Run at Creekside & 53.4 \\
\hline 39 & 03037200 & South Branch Plum Creek near Gastown & 40.1 \\
\hline 40 & 03038000 & Crooked Creek at Idaho & 191 \\
\hline 41 & 03038100 & Cherry Run near Brick Church & 14.2 \\
\hline 42 & 03039000 & Crooked Creek at Crooked Creek Dam & 278 \\
\hline 43 & 03039200 & Deer Run near Buckston & 3.7 \\
\hline 44 & 03039300 & Wells Creek at Mostoller & 16.8 \\
\hline 45 & 03039340 & Beaverdam Creek at Stoystown & 18.5 \\
\hline 46 & 03039440 & Quemahoning Creek at Boswe11 & 58.5 \\
\hline
\end{tabular}


Site Number Station Number

Site Name

Drainage Area

(square miles)

\begin{tabular}{|c|c|c|c|}
\hline 47 & 03039700 & Dark Shade Creek at Central City & 8.51 \\
\hline 48 & 03039750 & Dark Shade Creek at Reitz & 35.8 \\
\hline 49 & 03039920 & Little Paint Creek at Scalp Level & 12.4 \\
\hline 50 & 03039950 & South Fork Bens Creek near Ferndale & 18.1 \\
\hline 51 & 03039957 & Bens Creek at Ferndale & 41.6 \\
\hline 52 & 03040000 & Stonycreek River at Ferndale & 451 \\
\hline 53 & 03040100 & Little Conemaugh River at Wilmore & 49.5 \\
\hline 54 & 03040110 & Howe11s Run near Ebensburg & 12.0 \\
\hline 55 & 03040511 & South Fork at Souksburg & 62.2 \\
\hline 56 & 03041000 & Little Conemaugh River at East Conemaugh & 183 \\
\hline 57 & 03041028 & Hinckston Run at Minersville & 14.9 \\
\hline 58 & 03041500 & Conemaugh River at Seward & 715 \\
\hline 59 & 03041650 & Hendricks Creek near West Fairfield & 29.0 \\
\hline 60 & 03041700 & McGee Run at Brentzer & 22.2 \\
\hline 61 & 03041710 & Dutch Run near Blue Goose & 8.08 \\
\hline 62 & 03041720 & Elk Creek near Belsano & 18.6 \\
\hline 63 & 03041800 & Blacklick Creek at Vintondale & 46.7 \\
\hline 64 & 03041900 & Brush Creek at Claghorn & 21.8 \\
\hline 65 & 03042000 & Blacklick Creek at Josephine & 192 \\
\hline 66 & 03042040 & $\begin{array}{l}\text { South Branch Two Lick Creek } \\
\text { near Wandin Junction }\end{array}$ & 19.7 \\
\hline 67 & 03042061 & Dixon Run at Clymer & 10.7 \\
\hline 68 & 03042170 & Stoney Run at Indiana & 4.39 \\
\hline 69 & 03042185 & Yellow Creek near Pikes Peak & 21.8 \\
\hline 70 & 03042200 & Little Yellow Creek at Strongstown & 7.2 \\
\hline 71 & 03042230 & Little Yellow Creek at Suncliff & 15.1 \\
\hline 72 & 03042280 & Yellow Creek near Homer City & 59.5 \\
\hline 73 & 03042500 & Two Lick Creek at Graceton & 171 \\
\hline 74 & 03043990 & Aultmans Run near Lewisville & 19.9 \\
\hline 75 & 03044000 & Conemaugh River at Tunnelton & 1358 \\
\hline 76 & 03044800 & Loyalhanna Creek at Rector & 20.7 \\
\hline 77 & 03044850 & Mil1 Creek at Ligonier & 34.4 \\
\hline 78 & 03044990 & Fourmile Run at Darlington & 39.8 \\
\hline 79 & 03045000 & Loyalhanna Creek at Kingston & 172 \\
\hline 80 & 03045300 & McCune Run at Keystone State Park & 1.73 \\
\hline 81 & 03045480 & Crabtree Creek at Crabtree & 14.5 \\
\hline 82 & 03046150 & Whitehorn Creek near Shieldsburg & 4.38 \\
\hline 83 & 03047000 & Loyalhanna Creek at Loyalhanna Dam & 292 \\
\hline 84 & 03047480 & Blacklegs Creek at Clarksburg & 21.6 \\
\hline 85 & 03047497 & Long Run near Maysville & 6.33 \\
\hline 86 & 03048200 & Roaring Run near Orchard Hills & 8.27 \\
\hline 87 & 03048300 & Beaver Run near Slicksville & 19.1 \\
\hline 88 & 03048400 & Beaver Run at Paulton & 54.6 \\
\hline 89 & 03048500 & Kiskiminetas River near Vandergrift & 1825 \\
\hline 90 & 03048550 & Pine Run at West Vandergrift & 18.1 \\
\hline 91 & 03048850 & Little Buffalo Run near Fenelton & 14.3 \\
\hline
\end{tabular}


Appendix 1 Station names and drainage areas for surface-water sites (continued).

Site Number Station Number
Site Name
Drainage Area

(square miles)

Rough Run at West Winfield

Little Buffalo Creek at Silverville

Buffalo Creek near Freeport

Little Buffalo Creek at Cabot

Allegheny River at Natrona

Bul1 Creek at Tarentum

Allegheny River at New Kensington

Pucketa Creek at New Kensington

Little Deer Creek near Acmetonia

Plum Creek at Verona

Pine Creek near Ingomar

Girtys Run at Baderstown
17.3

24.4

137

$$
4.66
$$

11410

36.8

1500

25.7

14.0

20.5

13.2

11.4 


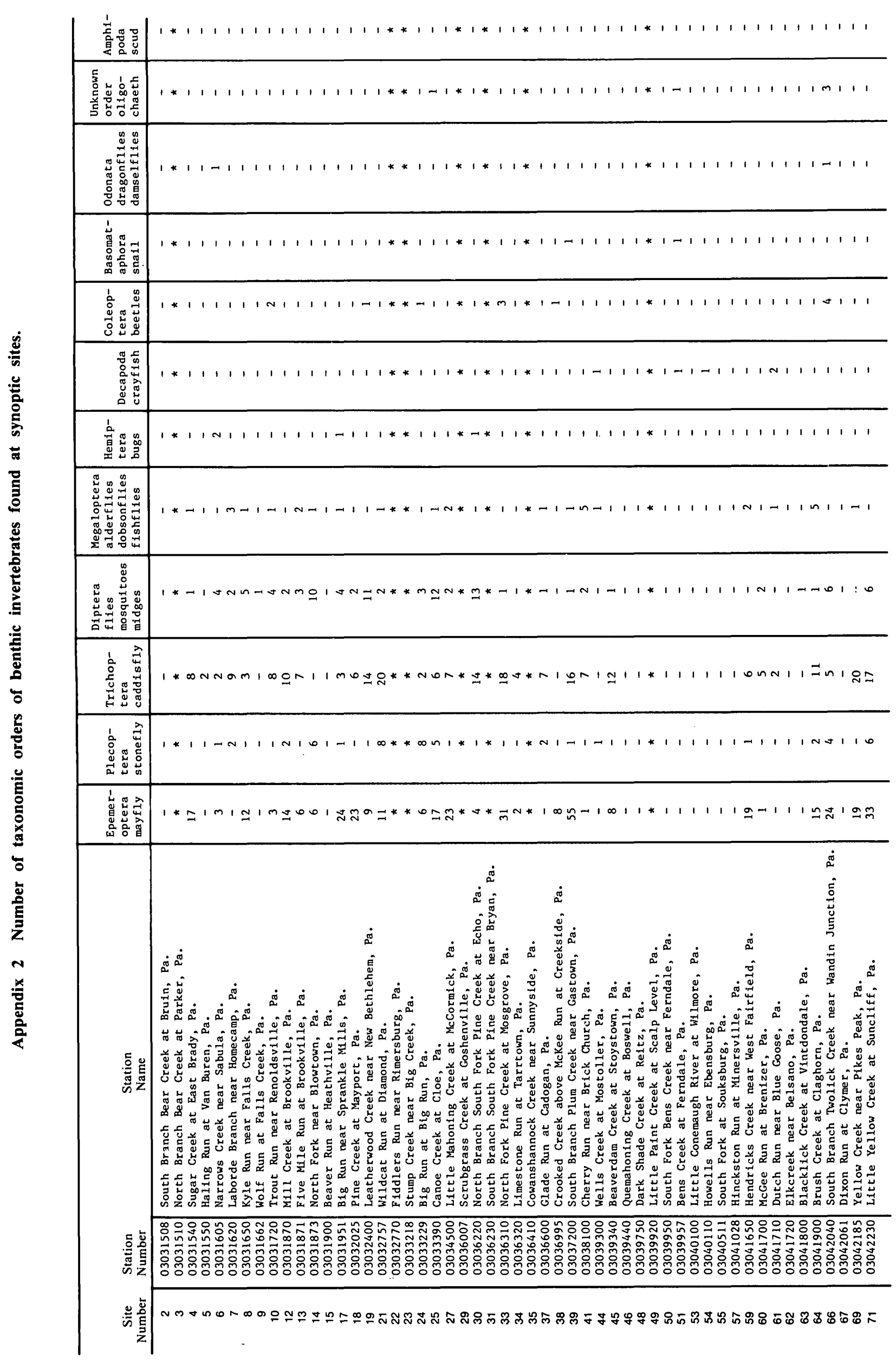




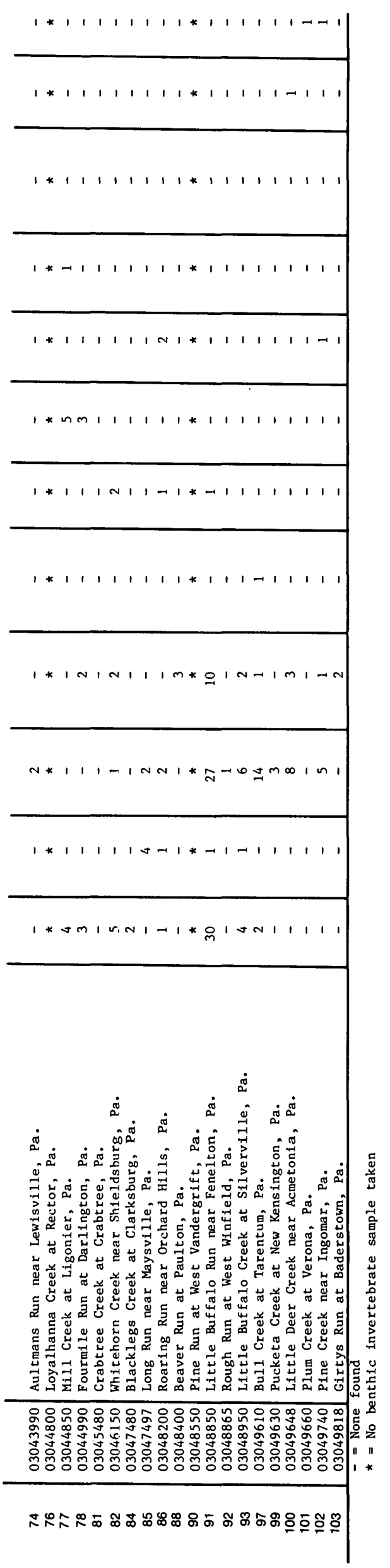

$?$

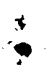

,

8 

